UNIVERSIDADE DE SÃO PAULO

FACULDADE DE FILOSOFIA, LETRAS E CIÊNCIAS HUMANAS

DEPARTAMENTO DE FILOSOFIA

PROGRAMA DE PÓS-GRADUAÇÃO EM FILOSOFIA

José Calixto Kahil Cohon

Técnica e Expressão na Filosofia da Música de Adorno

São Paulo

2013 - Versão Corrigida 
José Calixto Kahil Cohon

\title{
Técnica e Expressão na Filosofia da Música de Adorno.
}

\author{
Dissertação apresentada ao \\ programa de Pós-Graduação em \\ Filosofia do Departamento de Filosofia \\ da Faculdade de Filosofia, Letras e \\ Ciências Humanas da Universidade de \\ São Paulo, para obtenção do título de \\ Mestre em Filosofia sob a orientação do \\ Prof. Dr. Vladimir Safatle.
}

São Paulo

2013 - Versão Corrigida 
Agradeço especialmente

e infinitamente, minha mãe, Samira Peduti Kahil, em sua memória, que foi a principal motivadora de todo meu percurso acadêmico. Um exemplo de vida, na universidade, no afeto, na sabedoria e na criação.

meus familiares Carlos Alberto Cohon, João Casimiro, todos os parentes, com destaque para Judite, Suely, e Lígia, pelo apoio sempre presente.

os amigos próximos e amores - todos eles - em especial Lorena, Rafael, Enrique, Catarina, Douglas - pelas experiências de vida, na arte, na política e no tempo livre.

todos os grandes professores de música e filosofia que tive - Henrique Pinto, Maurício de Bonis, Everton Gloeden, Marilena Chauí, Leon Kossovitch, Leonardo Martineli e Antonio Ribeiro - e especialmente ao professor Vladimir Safatle pela força de seu pensamento, pelo seu incentivo instigante e pelos ensinamentos de questões centrais da filosofia e da arte.

todas e todos os funcionários do Departamento de Filosofia e da FFLCH.

A CAPES/ CNPq. 


\section{Resumo}

COHON, J. Técnica e Expressão na Filosofia da Música de Adorno. 2012. 142 f. Dissertação (Mestrado) - Faculdade de Filosofia, Letras e Ciências Humanas. Departamento de Filosofia, Universidade de São Paulo, São Paulo, 2013.

Trata-se de discutir as reflexões estéticas de Adorno em torno das categorias de Expressão e Técnica. Expressão e Técnica são categorias dialéticas constitutivas de toda obra de arte. A expressão como polo subjetivo e a técnica como polo objetivo; ambas em tensão fazem o movimento da história da arte. Nas obras tardias da filosofia da música de Adorno é possível reconhecer a importância de tais categorias em suas intervenções diante das vanguardas do pós-guerra nas quais encontramos as formulações mais instigantes, precisas e utópicas do filósofo compositor.

Palavras chave: Adorno, Expressão, Técnica, Música, Estética. 


\begin{abstract}
COHON, J. Technique and Expression on Adorno's Philosophy os Music. 2013. $142 \mathrm{f}$. Thesis (Master Degree) - Faculdade de Filosofia, Letras e Ciências Humanas. Departamento de Filosofia, Universidade de São Paulo, São Paulo, 2013.

It is to present reflections on Adorno aesthetic of music around the categories of Expression and Technique. Expression and Technical are dialectical categories that are constitutive to every work of art. The expression as subjective pole and technique as objective pole, both in tension, makes the history of art move on. In the late works of Adorno's philosophy of music is possible to recognize the importance of such categories in their speeches facing the vanguards of postwar where we found the most compelling, accurate and utopian formulations of the philosopher composer.
\end{abstract}

Key words: Adorno, Expression, Technique, Music, Aesthetic. 


\section{Índice}

Justificativa e Introdução ......................................................................... 7

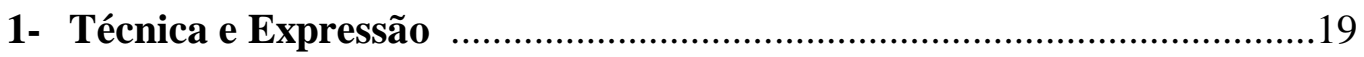

2 - Envelhecimento da Nova Música …......................................................... 54

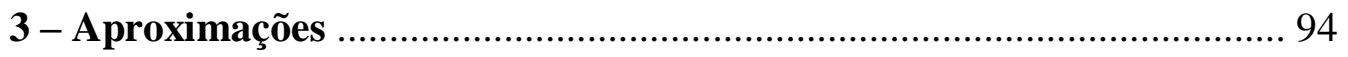

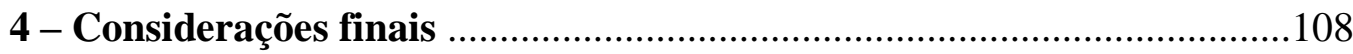

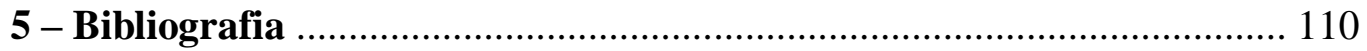

As referências bibliográficas de Adorno seguirão o seguinte modelo:

$($ ADORNO, TE, p. X) = ADORNO, T. W., Teoria Estética . Edições 70, Lisboa,

Portugual.1970.

$($ ADORNO, OC- X,p. X) = ADORNO, T.W., Obra completa, vol. Escritos Musicales $(13,14,16,17,18,19)$. Ed. Akal ,Madird, Espanha.2008

$($ ADORNO, FNM, p. X) = ADORNO, T.W., Filosofia da Nova Música. trad. França, M. , Ed. Perspectiva, 2002. 


\section{Justificativa e Introdução}

É simbólico que Theodor Adorno, um dos maiores filósofos do século XX, em grande parte de sua produção teórica tenha se debruçado sobre a experiência perante o objeto musical. Ligado à música desde a infância, Adorno elaborou junto a suas reflexões filosóficas mais famosas, como a Dialética do Esclarecimento e a Dialética Negativa, uma extensa reflexão estético musicológica: dos 23 volumes de sua obra completa no mínimo 10 se dedicam exclusivamente a temas relacionados à música. Atuante como filósofo, sociólogo, crítico, compositor e professor, é inegável que sua reflexão a respeito da música foi - e é - uma das mais determinantes na elaboração da crítica musical e cultural da atualidade. Se por um lado o interesse de Adorno com a música veio da tradição de seu berço alemão, por outro, a invasão do fato musical na vida cotidiana operada em nossos tempos torna a música um objeto privilegiado para a compreensão da humanidade no seu atual estado, questão que o filósofo nunca deixou 
de apontar. Além disso, para Adorno, a música, no interior do processo de evolução da sociedade, partilha diretamente as operações lógicas da racionalidade humana identidade e diferença, causa e consequência, verdadeiro e falso - mas até hoje a música verdadeira é uma espécie de mensagem numa garrafa jogada ao mar, uma vítima que na sociedade da racionalização total é signatária de incompreensão generalizada e de participação na irracionalidade socialmente organizada. A música - e toda arte - é um registro sismográfico das manifestações da subjetividade na experiência concreta de sua finitude que, no entanto, apresenta a face da infinidade metamorfoseante da história. E se a música fala uma linguagem que só expressa a si mesma em suas formas, ou seja, "palavras e conceitos não podem expressar o conteúdo musical diretamente", Adorno sabe que é possível enunciar diversas verdades na manifestação musical através de uma “forma mediada, ou seja, como filosofia" (ADORNO, 2, Beethoven, p.10).

Diante de tal extensa e fortuita produção muito já se disse sobre a estética musical de Adorno ${ }^{1}$. No entanto, ao observarmos estes comentários, notamos uma carência de reflexão específica sobre suas críticas e intervenções na década de 50 e 60 que, senão em raros momentos, são normalmente tratadas sem a devida centralidade e rigor $^{2}$. Em geral, tal produção se concentra no período que vai da década de 20 até o fim da segunda guerra, se centrando nos diagnósticos aporéticos da Filosofia da Nova Música ao lado da Dialética do Esclarecimento. No âmbito musical, tal carência de

\footnotetext{
1 Jorge de Almeida, 2000; Anne Boissiere, 1999; Carl Dahlhaus, 1970; Max Paddison, 1993; Richard Leppert; 2002; etc, só para citar alguns que se debruçam especificamente sobre a produção musical e estética de Adorno.

2 Diretamente temos como maiores comentadores da produção filosófica musical de Adorno no período tardio os contemporâneos Henz-Klaus Metzger, que travou intenso diálogo com o filósofo ainda em vida; Karl Dahlhaus, sem dúvida um irmão da tradição adorniana que comenta esparsamente diversos apontamentos de Adorno. No âmbito dos comentadores atuais em nossa pesquisa encontramos três comentadores que se debruçam um tanto mais demoradamente sobre tal produção: Anne Boissiere, em Adorno, a verdade na música moderna (1999) e que acaba de publicar um livro intitulado $O$ pensamento Musical de Adorno (2011); Edward Campbell em Boulez, Musica e Filosofia (2010), que dedica todo um capitulo à relação de Adorno com Boulez e a vanguarda de Darmstadt; e Max Paddison em Adorno's Aesthetics of Music (1993) que faz diversos e esparsos comentários a respeito da produção tardia do filósofo.
} 
reflexão sobre a produção tardia gera uma série de pré-conceitos e leituras errôneas de Adorno como, por exemplo, quando este é tomado como um conservador diante dos avanços vanguardistas da década de 60 , um representante da $2^{\mathrm{a}}$ escola de Viena estrito defensor do dodecafonismo de Schoenberg; quando se afirma que Adorno só é capaz de ter um pensamento musical ligado ao desenvolvimento de alturas motivo-temáticas, desconsiderando suas reflexões sobre a articulação de outros parâmetros musicais na composição; ou então que Adorno é um pessimista, distante de qualquer campo práticopolítico ou propositivo de atuação, encerrando seu pensamento em aporias negativistas. É claro que não se deve desconsiderar as reflexões sobre as obras da juventude, mas devemos salientar que sem a devida relação com os desenvolvimentos futuros da reflexão adorniana, corre-se o risco de aportar numa tendência de reificação de seu pensamento, o que pode impedir de brotar o germe crítico e fortuito, que já ali de início estava presente, mas que só tem seu desenvolvimento efetivo nas produções tardias.

Sem a devida relação com as obras tardias perde-se também uma das maiores riquezas do pensamento adorniano: a generosidade autocrítica de seu pensamento dialético. Seja pela dificuldade e amplitude de questões envolvidas ao se adentrar no debate da década de 50 e 60, seja por questões políticas, no que tange a temas ainda atuais e por isso polêmicos, tal descaso com a produção tardia nos surge como instigante desafio de elaboração.

Tendo em vista tal produção tardia fica evidente que as reflexões filosóficas de Adorno sobre a música são amplas e com diversas facetas: partindo de reflexões musicológicas sobre o domínio composicional técnico, passando pelos problemas de interpretação e reprodução musical, até as mais complexas mediações entre sociologia, psicologia e filosofia, Adorno apresenta um diagnóstico quase totalizante da situação da música no mundo moderno. No entanto, mesmo certos da unidade fragmento- 
sistemática das reflexões de Adorno, para esta dissertação nos ateremos principalmente ao polo de produção que é definidor das relações de produção - a composição musical sempre lembrando, no entanto, que medições dialéticas da influência das relações de produção sobre as forças produtivas são necessárias para se compreender os acontecimentos deste período.

Neste sentido reconhecemos na produção tardia de Adorno em debate com a produção composicional mais avançada da década de 50 e 60 seu elemento de maior fortuna e introduzimos aqui nosso objetivo a ser desenvolvido nesta dissertação: visamos desenvolver com Adorno aquilo que pode ser chamado de programa positivo de racionalidade e composição musical, ou seja, visamos apresentar críticas, categorias e processos que visem superar a atual racionalidade instrumental em vista de uma racionalidade que se reconcilie com a natureza do material e do sujeito. Parece-nos que para o filósofo superar a crise da razão diagnosticada na Dialética do Esclarecimento e na Filosofia da Nova Música era seu maior intento, e isso se manifesta em seus livros como Dialética Negativa, Teoria Estética além de diversos textos de intervenção de sua produção tardia. Para explicitar como tal objetivo será alcançado apresentaremos a seguir um resumo introdutório do caminho percorrido na manufatura de nossa dissertação.

Resumo da dissertação - Como ponto de partida em nossa dissertação nos concentraremos num debate mais amplo e central em torno do tema da natureza do acontecimento musical. É de comum conhecimento que as reflexões acerca das relações entre música, linguagem, ciência, sempre foram matéria sobre as quais tanto compositores como filósofos se debruçaram desde a antiguidade. Não foi diferente no curto período de tempo a que nos ateremos e talvez tenha sido um dos momentos mais 
profícuos em termos de produção intelectual de reflexão a respeito da música. Tal intensa reflexão a respeito da música tem sua justificação material: durante o século XX assistimos a um desenvolvimento exorbitante dos meios tecno-científicos. No âmbito estritamente musical, a tradição que percorreu séculos para separar ruído do som puro, controlar os tons para a expressão, constituir uma gramática de afetos ao lado de uma construção rigorosa, estabelecer um sistema notacional adequado, via-se agora atormentada pelas inovações no âmbito do ruído com os experimentos de orquestração timbrística e da música eletrônica; os estudos científicos de música espectral foram capazes de esmiuçar os formantes dos timbres abrindo todo um novo campo de utilização do contínuo de frequência sonora; o enfoque no âmbito do estritamente sonoro dando autonomia ao objeto musical, sem relações, sem sistemas, sem mesmo fisicalidade hierárquica, tratou de solapar a unidade lógica que a linguagem musical tradicional estabeleceu para si; também o problema da notação que desde o século XVII jamais viu debate tão intenso como neste período. Assim nosso primeiro capítulo se dedicará a uma reflexão precisa a cerca da relação entre as categorias de expressão e técnica em relação ao objeto musical na sua constituição tanto enquanto linguagem quanto próxima da ciência, debate este partilhado amplamente tanto por nosso filósofo Adorno como por compositores e estetas do período. Tal movimento inicial também visa preparar o leitor para o debate de Adorno com as vanguardas do pós-guerra, introduzindo-o nas principais concepções estéticas e musicológicas do filósofo, evitando que o discurso se feche aos especialistas.

$\mathrm{Na}$ sequência apresentaremos algumas intervenções de Adorno no debate musical tanto da primeira metade do século, como da segunda metade, fatura esta que visará apontar nuances comparativos da evolução do pensamento do filósofo diante dos acontecimentos e obras musicais, e apresentar um panorama interpretativo do 
pensamento de Adorno no período em questão. Da experiência aporética do desterro até a utopia da consolidação de uma nova racionalidade, o pensamento de Adorno não abandonou suas mediações entre os extremos, pois se o filósofo comumente tachado de pessimista teve sua razão de sê-lo frente ao horror de uma guerra nuclear, é nítido, principalmente nos textos tardios do autor, seu compromisso com a transformação progressista da humanidade em todos os aspectos, inclusive o estético. Daí o conteúdo de seus textos mais tardios, principalmente dos do final da década de 60 se mostrarem repletos de assertivas como "a verdadeira arte é aquela que..."; ou então "uma sociedade realmente humanizada só será aquela que...”. Este compromisso com a práxis, fundado na relação entre o pensamento especulativo sobre objetos concretos do mundo vital é signo da força de formular e intervir em nossa sociedade.

No âmbito especificamente musical o pensamento de Adorno foi de visível fortuna na determinação da práxis composicional do período. De início o filósofo adentra no debate musical do pós-guerra com aquele que é certamente o texto mais difundido da estética musical do século XX: Filosofia da Nova Música (1949). Elaborado criticamente, sistematizando matizes, definindo tendências e rupturas, e na mais ousada opção filosófica benjaminiana, apontando os dois polos extremos da produção musical da primeira metade do século XX, a Filosofia da Nova Música proveu a legitimação teórica e filosófica para os experimentos de serialismo que se seguiram após sua publicação ${ }^{3}$. A reflexão sobre conceitos como autonomia, fetichismo, retorno à origem, indústria cultural, dominação do material, são conceitos já elaborados neste texto, mas que ganharão outros contornos no debate consequente. Assim, nossa primeira aproximação com o debate do pós-guerra será precedida de uma avaliação

\footnotetext{
${ }^{3}$ Cf. PADDISON, 1993, pag. 265.
} 
sintética do diagnóstico da Filosofia da Nova Música perante as vanguardas da primeira metade do século XX.

O diagnóstico de fetichização do material tonal e a consequente exigência da busca por novos materiais para expressão de novas formas torna-se lugar comum no pensamento de Stockhausen e Boulez, para ficar com os exemplos maiores. Com o retorno do exílio para a Alemanha, Adorno passa a ser uma figura proeminente no debate cultural e musical, apresentando cursos e seminários na universidade de Frankfurt, falando em conferências e programas de radio e TV, e no que mais nos interessa, frequentando, nove vezes, os Cursos de Verão para a Música Nova de Darmstadt. É neste ambiente, em contato direto com a vanguarda do pós-guerra, representada por Eimert, Stockhausen, Boulez, Berio, Ligeti, Pousseur, Kagel, Cage, que o filósofo desenvolve suas mais arrojadas e engajadas intervenções teóricas na prática musical contemporânea.

A primeira participação de Adorno em Darmstadt foi em 1951 quando, como compositor, foi convidado para ministrar um curso de composição, substituindo Schoenberg, que estava com problemas de saúde e viria a falecer pouco tempo depois. Adorno, que havia estudado diretamente com Alban Berg, era literalmente um representante vivo da geração chamada de $2^{\mathrm{a}}$ Escola de Viena. Neste curso já se apresentou o primeiro atrito com os jovens vanguardistas na famosa anedota envolvendo Stockhausen descrita no artigo de Richard Toop ${ }^{4}$. Em 1949 Messiaen apresenta nos cursos de verão de Darmstadt seu estudo para piano Modos de Valores e Intensidades, no qual o compositor fazia uso de uma maneira de serializar as intensidades, durações e tipos de ataques no piano. Em 1950/1951, dois alunos de Messiaen, o belga Karel Goeyvaerts e o francês Michel Fano, compuseram sonatas para

\footnotetext{
${ }^{4}$ TOOP, Richard; Messiaen/Goeyvaerts, Fano/Stockhausen, Boulez; in Perspectives of New Music n.13, p. 142
} 
dois pianos estendendo o serialismo para todos os parâmetros sonoros. O segundo movimento da Sonata de Goeyvaerts foi então apresentado pelo próprio compositor, tocando ao lado do jovem Stockhausen de 22 anos, no referido curso de composição ministrado por Adorno. Segundo Toop, Adorno se mostrou bastante crítico à obra questionando sua unidade semântica no tempo: "Isto parece um amálgama de sons esparsos, onde está o antecedente e o consequente?" - questionou o professor, e o jovem aluno Stockhausen afirmou ironicamente "senhor, procurar isso nesta obra é como procurar uma galinha num quadro abstrato". A anedota, com seus contornos de quem acrescenta um ponto, é representativa do que Adorno significava para a geração do pósguerra: por um lado, uma autoridade quase ao nível de Schoenberg; por outro, um sábio filósofo da música diretamente ligado à geração passada que não conseguia se livrar de uma visão tradicional frente à música mais moderna. A música serialista, que então se apresentava como a mais verdadeira técnica composicional do pós-guerra, encontrava seu primeiro questionador.

A polêmica ganha forma completa em 1955 e 1956 quando Adorno publica o artigo intitulado $O$ envelhecimento da Nova Música, incorporado na coletânea Dissonâncias: Música no Mundo Administrado (1956). Com a publicação de Dissonâncias temos um panorama claro da amplitude da reflexão adorniana sobre a música, exemplificado pela variedade temática dos ensaios contidos no livro, pensado como uma intervenção objetiva na prática musical de seu tempo: 1. Sobre o caráter fetichista da música e a regressão da audição (1938) - texto fundamental na obra de Adorno que tem como aspecto central a mudança da função da música na sociedade de massas, tendo sido elaborado como resposta ao ensaio de Benjamin, Sobre a obra de arte na era da sua reprodutibilidade técnica; 2. Música Dirigida (1953) que consiste numa análise crítica e minuciosa do conteúdo ideológico e conservador das diretrizes 
tomadas pelo "Congresso Internacional de Compositores e Críticos Musicais dos Países da União Soviética"; 3. Crítica dos Musikanten (1954) sobre o movimento pedagógicomusical "Jovem Alemão" no qual Adorno vê reminiscências das tendências fascistas na cultura comunitária de músicos amadores; e por fim o texto sobre o qual primeiramente nos debruçaremos em nossa dissertação, o ponto de partida para o desenvolvimento da temática central de nossa pesquisa 4. O envelhecimento da Nova Música (1955), artigo em que Adorno apresenta uma ampla crítica aos rumos tomados principalmente por Boulez, Stockhausen e Pousseur no uso do serialismo integral. Neste texto fundamental, o filósofo aponta em termos gerais para uma perda da tensão estética das mais recentes obras da vanguarda, reafirmando algumas críticas já elaboradas na Filosofia da Nova Música, como o fetichismo do material no procedimento serial, o pontilhismo e congelamento temporal da música, uma crítica que este já endereçara à Webern, que era o principal modelo para os compositores da época. O texto causa enorme polêmica no meio musical e é amplamente difundido. Heinz-Klaus Metzger no texto "Just who is getting old?"5 ataca pessoalmente Adorno, acusando-o de incapacidade de compreensão das obras em questão. Por outro lado, compositores como Ligeti, aceitam e incorporam em suas leituras e reflexões as interpretações de Adorno.

O livro Dissonâncias teve três edições lançadas até 1963 o que mostra o reconhecimento da crítica musical de Adorno no cenário europeu e agora também no americano, sendo acrescido nas edições posteriores dos ensaios Sobre a Pedagogia Musical (1957) e Tradição (1960). No prefácio de Dissonâncias temos a seguinte afirmação de Adorno que citamos integralmente devido a seu conteúdo paradigmático:

“Os quatro ensaios reunidos no presente livro constituem uma unidade muito concreta. Estão dedicados a estudar o que acontece com a música no seio do mundo

\footnotetext{
5 METZGER, Heinz-Klauz. "Just Who is growing old?", Die Reihe 4, (Pennsylvania: Theodor Presser and Co., 1960). Texto este que, infelizmente, não tivemos acesso.
} 
dirigido, sob condições de planificação e organização prévias que arrebatam a base social da liberdade e espontaneidade artística. Tanto estética quanto sociologicamente, nosso ponto de partida nestas considerações é o seguinte: assim como os fenômenos de infantilismo artístico que serão elucidados tem seu fundamento na tendência social encaminhada desde a capitulação total do homem, o destino social da música - se não nos contentarmos com meras coordenadas - só advêm compreensível, inversamente, no interior da própria música e nas deformações que ela suporta por toda parte. Porque a tendência é universal, e as diferenças entre os setores musicais concretos se delimitam e se ligam de maneira tão escassa assim como as diferenças existentes entre os diversos sistemas políticos de hoje.“(ADORNO, 1966, p. 11)

Após a catástrofe da civilização europeia o horizonte não se tornou menos turvo com a polarização entre o capitalismo americano e o socialismo soviético. "No período da grande divisão política em dois blocos colossais, objetivamente compelidos a colidirem um com o outro, o horror continuou." (ADORNO, 1985, p.9) O impulso tecnocrático do progresso belicista dominava ambos os sistemas políticos colocando o destino da civilização sob uma heteronomia, reduzindo os sujeitos a mero quantum no todo social. "A concentração de poder econômico e, com isto, político e administrativo, reduz, em boa medida, cada indivíduo à condição de mero funcionário da engrenagem." (ADORNO, 1995, p. 30) A organização e planificação social geravam uma ausência de liberdade que trazia consigo a necessidade de uma autoridade que justificasse a falta de sentido nos caminhos do desenvolvimento social. Daí o retorno do misticismo e da superstição nos anos que se seguiram à guerra. "O modelo que realmente determina esta conduta [religiosa] é a divisão do mundo em dois blocos imensos, rigidamente contrapostos, que se ameaçam um ao outro e a cada indivíduo com a destruição." (ADORNO, 1995, p. 31). Frente a tal constrangimento social, o diagnóstico de Adorno sobre a música no século XX é o de uma crise da vida musical como um todo, um enrijecimento sem precedentes, como este aponta a respeito da unidade de seus ensaios 
compilados Dissonâncias: "A rigidez que ameaça invadir o todo, e ela é unidade de fato, se prefigura na unidade interna dos presentes ensaios" (ADORNO, 1966, p. 12)

Mesmo com toda a negatividade do pensamento de Adorno - que sabe que é melhor não propor caminhos a aceitar o curso heterônomo do mundo - a década de 60 , com a polarização da luta de classes, foi uma época de revoluções e de questionamentos. O filósofo da escola de Frankfurt, amplamente reconhecido por suas formulações de esquerda marxista, não deixou de participar ativamente dos debates e manifestações da época. Se no âmbito social, econômico e político, o clima era de tensão da Guerra Fria, no âmbito musical as disputas não foram menores. Por volta de 1960, Pousseur torna-se o primeiro dissidente do grupo de serialistas de Darmstadt, passando a um momento que se pode chamar de stravinskyano, onde o compositor trabalha com colagens, citações e teatro-musical. Os questionamentos de Cage ganham largo espectro de ressonância, fazendo com que diversos compositores passem a elaborar suas obras intuitivas e abertas ao acaso. É no interior deste momento tão tenso e singular da história do século XX que Adorno trabalha em suas maiores obras nas quais apresenta seus diagnósticos mais radicais, agora já somados à proposições práticas e objetivas.

A principal transformação operada por Adorno nesta década vem com texto sobre a Forma na Nova Música, que é fruto de uma conferência, no Simpósio sobre a Forma nos cursos de Darmstadt, debate este que será articulado com os contemporâneos textos sobre a forma de Dahlhaus e Ligeti. Para Deliége ${ }^{6}$, famoso esteta e historiador da vanguarda do pós-guerra, o tribunal elaborado pela reflexão destes três atores do debate musical marcou a derrocada do dogma serialista. Em nossa dissertação faremos uma

6 DELIÈGE, Célestin. Cinquante Ans de Modernité Musicale: de Darmstadt à L'IRCAM. ed. Mardaga. Bélgica, 2003. P. 503. 
leitura comparativa e relacional dos textos dos três autores em questão para compreender como o problema da forma foi fundamental para a superação do paradigma serial e de sua problemática tantas vezes criticada por Adorno.

Elaborando este caminho assim apresentaremos um panorama introdutório ao debate da década de 50 e 60, trazendo a tona o compromisso de Adorno na apresentação de uma nova maneira de pensar, uma nova maneira de pensar a composição, e assim, vislumbrar uma nova maneira de perceber o mundo e almejar a liberdade humana.

Por fim, estabeleceremos duas aproximações suplementares ao projeto central desta dissertação. A primeira diz respeito ao debate acerca da reprodução musical, onde visamos nos focar nas elaborações de Adorno a respeito da interpretação e recepção musical, elaborações do filósofo que passam longe de ser marginais; é notória a importância da questão da interpretação tanto para a vanguarda musical quanto para o movimento de música antiga e interpretação historicamente orientada que surge nos anos 50 e 60. A segunda versa sobre o compositor Gyorgy Ligeti e se justifica, para além da presença deste no debate e produção da vanguarda do pós-guerra, no intenso diálogo direto com as reflexões de Adorno que aparece compilado em seu livro Nove ensaios sobre a Música ${ }^{7}$.

\footnotetext{
${ }^{7}$ LIGETI, G. Neuf Essais sur la musique. trad. Fourcassié, C., Editions Contrechamps, Genéve,2001.
} 


\section{1 - Técnica e Expressão}

As categorias de expressão e técnica são centrais no âmbito da manifestação artística e especialmente importantes na experiência intelectual de Adorno. Como veremos a seguir, o lado expressivo apresenta o sentido do gesto mimético, portando tudo aquilo que é humano e que mesmo assim pode nos ser estranho, enervando as percepções, seguindo o impulso projetivo do Eu que se expressa, o reflexo que move, a força que no limite dissolve esse próprio Eu ao colocá-lo em contato com a objetividade modulante; quiçá uma representação de fantasia, uma aparência, a comunidade e a utopia de um mundo com menos sofrimento. A expressão como olhar das obras que fala uma linguagem própria, uma linguagem humana e das coisas. Por outro lado, em confronto e tensão, em unidade e diferença com a expressão, há o domínio da construção técnica: é preciso reconhecer o pensamento próprio da arte, sua lógica e seu artesanato, sua dominação racional e mecânica, sua ordem e organização, a ciência e o progresso da arte; técnica da qual é possível depreender modelos e maneiras de operação do intelecto humano e apresenta também uma utopia humana: num plano superior, a reconciliação com a natureza. A técnica como coleção de conhecimentos, 
formas de construção arquitetônica e matemática de um objeto, aliada às convenções práticas de organização e uso.

Entre estas duas faces, que se tocam como extremos distanciados, a promessa de felicidade da arte se desenha e se esfumaça. O equilíbrio tenso entre o sentido da expressão humana e domínio técnico da natureza oferece assim, tanto uma perspectiva de constituição da arte, quanto uma possibilidade de reconciliação do homem com o mundo, que a arte sempre apresenta como possibilidade e como fracasso. Como apresentaremos a seguir, a articulação tensa entre estas duas categorias é que possibilita para Adorno a configuração de um modelo autêntico de operação dos processos de criação da obra de arte.

Expressão e Técnica - Para reconhecer a importância destas categorias e introduzirmos o debate neste capítulo apresentaremos como estas categorias participam ativamente tanto no debate estético de Adorno quanto na teoria dos próprios compositores do período. Para atestar tal importância basta lembrar algumas afirmações idiossincráticas de Adorno:

\footnotetext{
“A música expressiva tem um comportamento mimético, imitativo, à maneira de como os gestos respondem a um estímulo com o qual se igualam no reflexo. Na música este componente mimético vai pouco a pouco se confrontando ao componente racional, ao domínio do material: este conflito faz sua história. Porém, entre eles não se efetua uma reconciliação: também na música o princípio racional, o princípio da construção, tiraniza o princípio mimético. Este último se vê impelido a afirmar-se polemicamente, a implantar-se a si mesmo; o expressivo é o protesto admitido, consentido, da expressão contra a proscrição lançada contra ela. Quanto mais o sistema musical da racionalidade se petrifica, menos a expressão encontra seu lugar.” (ADORNO, Mahler, pág. 39).
}

Esta citação se insere no capítulo "Tom" da monografia de Adorno sobre Mahler. No interior de uma reflexão a respeito dos caracteres singulares que manifestaria a maneira artística de Mahler, Adorno desenvolve um longo trecho a respeito da importância da categoria de expressão. O contexto de Mahler é exemplar para se pensar o problema da expressão diante da construção técnica, pois, é exatamente na virada do século XIX para o XX que o sistema tonal se encontrava explorado ao seu limite e as suas possibilidades expressivas se petrificavam em decorrência do acúmulo de convenções técnicas herdadas do passado. Foi contra o fetiche da aparência e a naturalização desta carga convencional que as vanguardas do início do século se 
voltaram contra, em sua rebelião contra a aparência, o que exigiu uma outra relação histórica entre expressão e técnica:

“A transformação dos veículos de expressão da música quanto ao material, processo que segundo Schoenberg se verifica continuamente no curso de toda a história da música, tornou-se hoje tão radical que expõe o problema da própria possibilidade da expressão. A coerência da própria lógica petrifica o fenômeno musical cada vez mais e o converte de entidade densa de significado em algo que simplesmente existe e é impenetrável em si mesmo" (ADORNO, FNM, 25).

Como vemos, Adorno apresenta mais uma vez as categorias de construção técnica e de expressão para pensar o desenvolvimento histórico da música, neste caso, na esteira das formulações schoenberguianas. O século XX, século dos extremos, viu o desenvolvimento da arte musical oscilar entre a exigência de expressão radical colocada pelos compositores e a utopia do avanço progressivo no âmbito do domínio técnico do material, elaborado em formas de construção que tendiam ao integral e que cada vez mais dominavam a natureza do fenômeno sonoro. No interior deste cenário Adorno é um crítico incisivo do progresso positivista que a vertente tecnicista adota. Para Adorno, cabe sempre apontar o preço que cobra o progresso no âmbito do domínio material, questão esta que ficará clara no debate do pós-45. Adorno, aluno de Berg, se insere no interior deste cenário ao lado dos paradigmas postos por Schoenberg, que, por exemplo, numa introdução de seu manual de composição, após um longo trecho explicando como o estudante deveria se preparar tecnicamente para compor reafirma a necessidade da expressão:

“O que produz a música verdadeira é única e exclusivamente a capacidade inventiva, a imaginação e inspiração de uma mente criadora - sempre e quando um criador "tenha algo a expressar". Não obstante, um estudante nunca deveria escrever meras notas áridas. Em todo momento deve tratar de "expressar algo". (...) Feito isso, pode assim um estudante escrever com maior espontaneidade, a qual não exclui a consciente aplicação de seu conhecimento técnico.” (Schoenberg, A., Modelos Para Iniciantes em Composição, 1943).

Se compararmos esta afirmação de Schoenberg com a reflexão de alguns dos expoentes da vanguarda do pós-guerra é notável a mudança de perspectiva. Basta ver, por exemplo, o que pensava Stockhausen, numa entrevista relatada e citada por Fubini: 
"'Hoje em dia, é distinto o modo de aproximar-se da música: no que me concerne, tenho um modo científico de aproximar-me; quer dizer, o modo como um biólogo que pretende ver como estão as coisas. (...) Já não me interessa em nada a questão da expressão.'" (FUBINI, E. , Música y Lenguaje en la estética contemporánea, trad. ARANDA, C.G.P., Alianza Editorial, Madrid, 1994.)

Como veremos, já Stravinsky não passava longe de afirmações próximas das de Stockhausen. A equiparação do artista com o artesão, com o cientista não passa alheia ao diagnóstico de Adorno, que formulava uma ampla crítica da especialização e cientifização conservadora dos domínios do saber. Para dar mais um exemplo de como o problema da técnica e da expressão era central neste debate, podemos lembrar daquele que protestou conscientemente contra tal estado do fetiche da dominação do material, John Cage:

"Deve-se ver a música de maneira muito natural. Nenhuma técnica totalmente: apenas a técnica que o funcionamento exige. Eu me lembro de ser questionado sobre como eu pensava a técnica. De início eu não tinha nada que dizer. Alguns dias depois eu percebi que não tinha tempo para a técnica por que eu tinha necessidade de estar sempre criando uma: qualquer técnica pode ser descoberta depois que qualquer técnica é esquecida." (CAGE, Silence, p. 149).

Ou então:

“A arte como arte é ordem ou expressão, ou a integração destes. Ela é uma luz, diz o Chinês, mas que advém obscura." (CAGE, Silence, p. 166.)

E por fim:

“O controle deve ir até um ponto apenas e alocado de maneira a não ter nenhum efeito no que acontece: uma técnica que resulta em ausência de técnica.” (CAGE, Silence, p. 188.)

Como veremos Cage surge como crítico da razão dominadora depois de um longo período construtivista em sua obra; como um pêndulo, passa ao extremo oposto. Desta rápida compilação de fragmentos, cremos ser possível notar a centralidade desde debate nos textos e nas obras de diversos representantes da vanguarda do século XX. Para introduzir o debate nos textos do pós-guerra, primeiramente faremos uma 
apresentação teórica mais aprofundada das categorias de expressão e técnica a partir do pensamento de Adorno. Como veremos, num momento em que vivemos um imperativo tecnocrático na sociedade do progresso positivista, recuperar a autenticidade categoria de expressão, com sua necessidade de sentido e humanidade latente torna-se protesto admitido contra o atual estado das coisas. Pois a técnica é fundamental para a libertação humana, mas sem a articulação de um sentido preciso, sem a reconciliação não violenta com a natureza, tanto interna quanto externa, ela continuará a ser perniciosa.

Progresso e autonomia - O termo tékhné tem como significado 'arte manual, indústria, artesania.' Já o termo ars, e seu análogo grego poesis, significam conhecimento técnico por oposição ao latim natúra - 'habilidade natural - ou seja, ars é tudo que é de indústria humana, ciência, ofício, instrução, conhecimento, saber, profissão, destreza, perícia, habilidade, qualidades adquiridas. Já nesta simples etimologia fica nítida a relação direta entre a esfera da arte e a técnica, o saber, a indústria e a ciência da natureza. Podemos afirmar então, que a arte é compreendida neste sentido como aquilo que é fabricado pela técnica e se determina por negação mediante a sua relação com a natureza. A música poderia ser definida desta forma como a arte da dominação técnica da natureza do fenômeno sonoro; a indústria, o ofício e o saber manipular a qualidade sonora dos objetos. A história da música seria a história do progresso da consciência deste processo, manifesto na sua autonomização e desenvolvimento técnico.

Se até o período medieval a unidade dos conhecimentos sob o signo das belas artes permitia que mito, método, ciência e artesanato fossem colocados sob a mesma esfera, a divisão social do trabalho que acompanha a superação da manufatura levou a uma autonomização progressiva das esferas sociais, que por sua vez, também teve seu correlato na arte que só então encontrava seu espaço no campo das especialidades. No entanto tal autonomia deve ser entendida de maneira dialética. A mesma especificidade técnica que garante a separação das esferas é responsável pela mediação do lado heterônomo da arte, sua relação com a sociedade. A técnica é, para Adorno, a única capaz de fazer a mediação com a sociedade, a única que permite a decifração do conteúdo social da música:

"A sociedade adentra nas obras a partir do estado da técnica. Entre as técnicas de produção material e as da produção artística vigoram afinidades bem mais íntimas 
que as que reconhecem a divisão científica do trabalho." (ADORNO, Introdução à sociologia da música, p.405)

No desmembramento dos processos artesanais em direção à racionalização do trabalho fabril, Adorno encontra correlato no trabalho motivo-temático empreendido por Bach, que opera por dissociação e síntese no mesmo movimento. "A dinamização da sociedade e a dinamização da música possuem sentido idêntico" (idem, pág. 406).

Para compreender melhor o que significa este movimento histórico-estético de autonomia e heteronomia é preciso fazer recurso à compreensão de Adorno a respeito do progresso, da racionalização e autonomização do material musical, questão essa amplamente desenvolvida por Max Weber em seu Fundamento Racionais $e$ Sociológicos da Música do qual a tese sociológica de Adorno certamente se apropria. Safatle $^{8}$ é preciso ao apontar como a crítica adorniana da racionalização no ocidente é pensada com Weber através de um processo triplo: desencantamento, dominação pelo cálculo e consolidação de legalidade própria de cada uma das esferas de valores. Tal proximidade do pensamento de Adorno com Max Weber fica latente em afirmações como a que segue, a respeito do progressivo momento de desencantamento da esfera da arte:

"A arte constitui um momento no processo do assim chamado por Max Weber desencantamento do mundo, implicado na racionalização; todos os seus meios e métodos de produção dela procedem; a técnica, que declara herética a sua ideologia, que tanto lhe é inerente como a ameaça, porque a sua herança mágica se manteve tenazmente em todas as suas transformações." Adorno, TE, 69.

Por desencantamento Weber tem em vista a liberação das justificações do mundo fundadas nas concepções anímicas, mitológicas e religiosas. O desencantamento da música é a sua liberação de qualquer ligação essencial às funções rituais. Se até hoje a música é utilizada com diversas funções sociais, talvez a mais antiga seja a função anímica e ritualística. Longe de ser contemplada pelas suas qualidades estéticas internas a música era "subordinada a fins práticos, em primeiro lugar sobretudo mágicos" (Weber, Fundamentos Racionais, pág. 87). A técnica do mago feiticeiro não é diferente da técnica do artista, que ilude com a aparência fantasmática do gesto e da imitação. Os

\footnotetext{
${ }^{8}$ Safatle, V. Fetichismo e mimesis na filosofia da música adorniana, em Discurso n37.ed. Alamedam pág
} 389. 
hieróglifos nas paredes retratavam os animais na crença de que sua aparição enquanto artefato produzido participava da criação da natureza: retratá-la era já uma tentativa de dominá-la. As técnicas mágicas dos povos primitivos envolviam a manifestação artística numa união identitária entre o gesto humano e a ordem da natureza; não é música que fala, mas sim, cantam as musas.

Um exemplo historicamente mais concreto é visível no advento da estrutura religiosa no ocidente, onde o processo técnico passa a ser mediado em vista das representações miméticas, ao lado do avanço na capacidade de manipulação do material musical. Weber, que se limita a pensar a música ocidental, tem em mente a esteriotipização de intervalos, escalas e modos. Exemplo disso seria a sistematização dos modos pelo Papa Gregório I no século VI com fim de organizar a liturgia por todo o império católico romano. Neste período, mais uma vez a técnica está a serviço da ordem mágico-religiosa, mas agora a técnica surge envolta em mediações filosóficas que justificavam conscientemente as representações aliadas aos procedimentos de domínio do material. Deus sopra ao ouvido do sacristão e este reapresenta sua mensagem ao mundo sob a forma de um cantochão. Para ilustrar a filosofia que estava por trás deste estágio da consciência na história musical Palisca afirma:

“A sua filosofia determinava que a música fosse serva da religião. Só é digna de ser ouvida na igreja a música que por meio dos seus encantos abre a alma aos ensinamentos cristãos e a predispõe para pensamentos santos. Uma vez que não acreditavam que a música sem letra pudesse produzir tais efeitos, excluíram, a princípio, a música instrumental do culto público.” (Grout \& Palisca, história da música ocidental, pág 43.)

O conflito com a manifestação autônoma expresso na condenação da forma da música instrumental pela igreja é mais uma evidência da submissão da música a fins exteriores. Conforme nos esclarece Safatle, para que o processo progressivo de emancipação se dê "há um encantamento do material musical que deve ser rompido com a autonomização da música em relação a toda função ritual.” (Safatle, Fetichismo e mimese na filosofia da música adorniana pág. 389) Tal processo começa a dar seus primeiros passos com a emancipação da música secular durante o século XV mediante a ampliação da elaboração de motetos polifônicos e a força do movimento trovador. No entanto, este movimento de desencantamento da música só se consolidaria durante o classicismo, época iluminista por excelência, mediante a instauração de salas de 
concerto e a emancipação das formas de música instrumental, o que permitia pela primeira vez a contemplação da qualidade estética do acontecimento musical autônomo. Assim, se como aponta Max Weber, a história da arte é a história do seu desencantamento poderíamos facilmente cair na crença de um progresso positivista, uma flecha sem restos e sem desvios. Contra isso Adorno aponta que o pensamento mais verdadeiro deve ser capaz de reconhecer aquilo que na arte resiste à dominação e ao desencantamento, tendo em vista, por exemplo, o que resta de magia na arte:

“A separação só pode ser anulada pela separação. Isso fortifica na arte o momento racional e exorciza-o ao mesmo tempo, porque ele se contrapõe à dominação real; sem dúvida, enquanto ideologia, alia-se sempre de novo a ela. Falar de magia da arte é palavreado, porque a arte é alérgica à recaída na magia. (...) No entanto, o palavreado sobre a magia da arte evoca algo de verdadeiro. A sobrevivência da mimese, a afinidade não-conceitual do produto subjetivo com o seu outro, com o não estabelecido, define a arte como uma forma de conhecimento e, sob este aspecto, como também «racional». “ADORNO, TE, 69

A complexa dialética de Adorno é capaz de reconhecer a superação da magia e da função ritual na arte sem no entanto abandonar a capacidade mimética da arte que a mantém unida ao aspecto ilusório, por dizer, ideológico, de uma esfera de manifestação humana que fala uma linguagem racionalizada, mas sem conceito. Trata-se de um resto mimético que une a arte à natureza, fazendo-a falar, como nos ritos primitivos, uma linguagem das coisas, do mundo. Mas é preciso lembrar que arte é, para Adorno, sempre racional, inclusive nos contatos com seus extratos irracionais. Por isso Adorno afirma que nenhuma arte é puramente técnica como almejaram diversas vertentes das vanguardas do século XX. O filósofo não deixa de reconhecer que a compreensão desta impossibilidade - da arte totalmente técnica - só tenha vindo à tona no confronto com as obras que se radicalizaram nesta direção. Até então a compreensão da arte, tanto seu extrato mágico como seu estrato formal, permaneceu subjulgada a fins exteriores que sempre levaram ao "palavreado" combatido por Adorno.

Mas como vimos, o progresso intra-estético das obras de arte, não é dependente apenas de sua liberação da função social e da consciência de sua autonomia. A constituição de uma esfera de legalidade própria e a compreensão do fenômeno da dominação racional pelo cálculo também participam ativamente neste movimento histórico. Como nos esclarece Leopoldo Weizbort em sua introdução ao livro de Weber: 
“A autonomização da arte, sua libertação das finalidades práticas, corresponde o início da "verdadeira racionalização", pois que a autonomização da esfera artística engendra a legalidade própria dessa esfera, que é justamente a sua racionalização específica- isto é, uma racionalização que possui uma direção específica dentre outras possíveis, e essa direção está relacionada justamente com essa esfera particular. A pergunta sobre a racionalização própria à música - e à arte em geral - encontra sua resposta no fato de que, na arte, a racionalização se projeta sobre os próprios meios artísticos. Assim, a racionalização da música é a racionalização dos meios musicais: dos sistemas sonoros, dos instrumentos, das formas composicionais etc." (Leopoldo Weizbort, introdução ao Fundamento racionais, pág. 39)

O progresso da música como progresso de seus meios, ou seja, a evolução da notação, da construção e possibilidades dos instrumentos, da constituição de sistemas e formas musicais, dos sistemas de afinação. Se pensarmos que, por exemplo, como aponta Adorno ${ }^{9}$, o surgimento da polifonia é fruto do progresso intra-técnico das obras de arte, é possível reconhecer que tal movimento de autonomia, de constituição de uma legalidade própria no âmbito da construção das obras tem seus primórdios no século XII com a criação dos primeiros sistemas de notação musical. O organum - composição polifônica desenvolvida em Notre Dame neste período - é um bom exemplo dos primeiros indícios desta autonomização. Com a racionalização e ordenação dos modos, tanto de alturas como de ritmo no âmbito da escrita musical, era possível constituir um todo orgânico que derivasse de uma célula comum, em geral um cantus firmus, cantochão. Por mais que o texto ainda desse suporte a forma geral e duração destas obras, o elemento autônomo já se via na maneira de ordenar e construir as vozes complementares, o que se dava de maneira orgânica, ou seja, de maneira que as partes tivessem uma relação direta com o todo: a forma começava a se autonomizar na medida em que seu procedimento técnico era um desdobramento de questões puramente musicais; a polifonia com sua funcionalidade sem fim fechava-se em si mesma. É simbólico que a primeira "obra" autoral, com diversos "movimentos", possa ser considerada a missa polifônica de Notre Dame do mestre da ars nova Guillaume de Machaut. A constituição de um todo sistemático fechado em si mesmo, no caso em torno de um cantochão, só pode ser produzida sob o signo do progresso da técnica de

9 “Os materiais históricos e o seu domínio, isto é, a técnica, progridem de modo incontestável; descobertas como as da perspectiva na pintura, da polifonia na música são disso os exemplos mais evidentes" (adorno, TE, 237) 
escrita. É certo que neste caso a constituição de uma esfera de legalidade própria ainda não estava dada, mas a possibilidade técnica de uma obra de arte musical ser construída a partir da criação de regras que dizem respeito somente à ordenação interna do seu próprio material já se fazia ver no horizonte. Tal fato fica latente na crítica subsequente do comando da igreja na contra-reforma, uma crítica à obscuridade da expressão polifônica que ocultava a então oficial função da música de comunicar os textos bíblicos.

Para compreender o desenvolvimento da autonomia por completo é preciso apresentar o terceiro vetor de autonomização e racionalização da música que diz respeito à dominação pelo cálculo. Este é talvez o mais técnico dos avanços progressivos da música. Desde Pitágoras até a música estocástica do século $\mathrm{XX}$ as relações entre música e matemática foram determinantes para o desenvolvimento da arte musical. A divisão do monocórdio, a contagem do pulso que estabeleceu os padrões rítmicos, a análise espectral que permitiu a compreensão dos formantes de um timbre, a música algorítmica, são todos exemplos de cálculos matemáticos que permitem a criação do discurso musical. Max Weber tem em vista principalmente a consolidação do sistema tonal aliado à constituição do temperamento. De fato, a capacidade de diferenciação, sistematização, controle, funcionalização e demarcação de plano geral da forma só foi possível com a organização do sistema tonal, que aliado à constituição do temperamento igual permitia a ampliação do campo modulatório nos instrumentos harmônicos. É inevitável lembrar de Rameau que no seu Traité de l'harmonie reduite à son príncipe naturel (1722) afirmava:

“A música é uma ciência que deve ter por regras estabelecidas; estas devem derivar de um princípio evidente que não se pode revelar sem ajuda da matemática" (RAMEAU, traité, introdução)

Conforme atesta Safatle:

“se é verdade que uma esfera social de valor será mais racional na medida em que estabelecer seus processos de valoração através de um plano sistêmico de organização - plano que tira de si mesmo sua própria certificação -, então é com a consolidação do sistema tonal que a música entra na modernidade" (Safatle, Fetichismo..., pág 391) 
Tomemos um exemplo para apresentar este elemento de autonomia evidente no domínio harmônico do sistema tonal. Ao atentarmos para a publicação de Rameau em 1727 de seu livro de Novas Peças para Teclado ${ }^{10}$ é possível reconhecer a força do progresso da técnica no âmbito da harmonia. No título das peças é possível reconhecer o como o avanço do domínio do material contribuiu tanto para a capacidade imitativa quanto para a manifestação formalista e autônoma da expressão musical. Se por um lado vemos as imitativas Le Poule, Les Sauvages e as formas herdadas da música de dança, por outro surgem músicas cujo nome diz respeito simplesmente a procedimentos técnico-construtivos: temos peças com nomes de técnicas de execução ao modo das formas dos estudos, mas também peças cujo título diz respeito a uma técnica composicional. L'enharmonique é exemplar neste caso. A peça é um belo exemplo de como o avanço da capacidade de dominação técnica do temperamento musical abriu novos caminhos expressivos na arte musical. No prefácio à coletânea Rameau afirma a respeito da peça:

"O efeito experienciado no décimo segundo compasso da Reprise da Enharmonique certamente não será do gosto de todos; de qualquer forma pode-se acostumar com ele após uma pequena dedicação e tomada de consciência de toda a sua beleza, de modo que a aversão inicial, que neste caso resulta da falta de familiaridade, será superada. A harmonia que cria este efeito de maneira alguma é fruto do acaso; ela é baseada na lógica e tem seu fundamento na Natureza mesma; seu ingrediente pode ser saboreado pelo conhecedor; de qualquer forma, sua performance deve manifestar a intenção do compositor através de um relaxamento do toque e pela suspensão cada vez maior das apogiaturas conforme se aproxime o trecho do trilo onde uma pausa momentânea é indicada com o signo da fermata." (Rameau, Novelle, pág. 58)

${ }^{10}$ RAMEAU, J. P. "Pièces de clavecin - third collection" ed. Edwin Jacob. Bärenreiter, Bassel. 


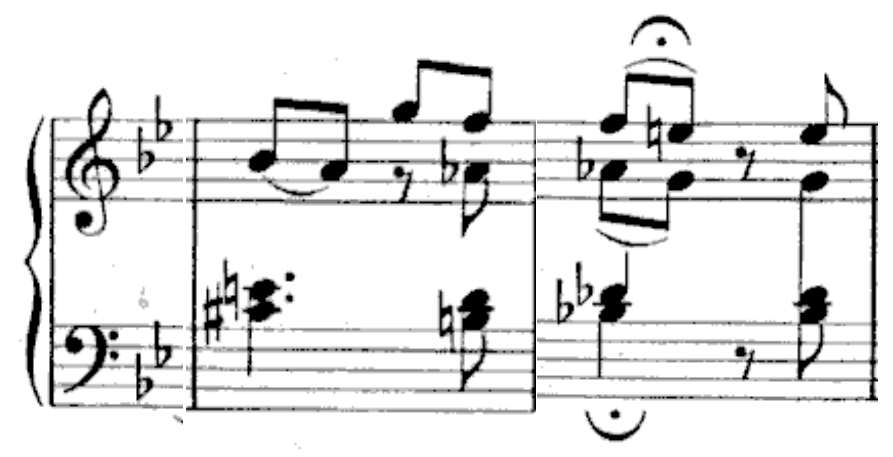

No trecho em questão Rameau faz uso de uma transição harmônica que só foi possível de ser concebida com o avanço da dominação técnica das manipulações do temperamento musical. Com o estabelecimento do temperamento igual adotado por Rameau as notas $\mathrm{C \#} \mathrm{e} \mathrm{Db} \mathrm{tornam-se} \mathrm{pela} \mathrm{primeira} \mathrm{vez} \mathrm{notas} \mathrm{iguais.} \mathrm{Em} \mathrm{outros}$ temperamentos, como o mesotônico, essa passagem manifestaria uma "desafinação" intensa.

A peça tem como tonalidade principal Sol menor. Sua reprise acontece na relativa maior Si bemol maior. No trecho em questão a harmonia é direcionada para a tonalidade de Mi bemol maior para logo em seguida retornar para Sol menor. Rameau apresenta com esta técnica na manipulação da harmonia um momento de suspensão do fluxo harmônico.

Que o uso de um tipo de modulação seja responsável por um clímax expressivo é o símbolo da força que a tensão entre expressão e técnica manifesta. A força de sua expressão decorre que esta inovação simplesmente não vivia no âmbito da "familiariedade", ou seja, no aspecto convencional daquele tempo. No entanto, por mais que o momento expressivo surja aparentemente como desagregação da forma, internamente ele é construtivamente e racionalmente justificado. Do tensionamento da forma sobre si mesma, da expressão da forma sobre si mesma, surge uma mimese “inominável”. O conteúdo expressivo da modulação enarmônica é indefinido no âmbito da mimese imediata, pois se manifesta enquanto expressão puramente formal, autônoma; expressão de uma manifestação enarmônica puramente musical. Esta manifestação puramente sonora, abstrata, mas de grande "efeito" expressivo, decorre diretamente da modulação que multipolaridade resolutiva dos acordes diminutos possibilita, modulação esta que só foi possível com o desenvolvimento técnico do temperamento igual. A força expressiva que surge neste trecho particular é totalmente 
dependente de um sistema universal de referencia. Só quando é elaborado no interior de uma relação universal e sistemática é que o elemento particular pode entrar em tensão com o universal. Assim, o sistema tonal torna-se pressuposto deste tipo de expressividade e ao mesmo tempo o índice de sua realização por via do que o nega.

O fato decisivo deste exemplo é que a autonomização e racionalização manifesta como modelo na constituição do sistema tonal permitiu que a música se organizasse como linguagem fechada sob si mesma, linguagem que fala de si mesma, de seus próprios procedimentos técnicos, o que abriu as portas para a compreensão do fenômeno musical "puro", sem fazer recurso a elementos miméticos exteriores, fato que só passaria a ser mais bem compreendido no fim do século XIX com o advento do formalismo de Hanslick ${ }^{11}$.

A autonomia do sistema tonal fica exemplarmente atestada quando lembramos que Kirnberger, pesquisando invenções mozartianas, foi capaz de aproximar a linguagem musical tonal do jogo, modelo de autonomia conforme a teoria de Huizinga $^{12}$. Trata-se de um jogo de criação de minuetos:

"Teóricos do século XIII como Kirnberger (Der allezeit fertige Polonoisen- und Menuettencomponist, 1757) usaram o minueto como um exercício elementar de composição, e o processo foi reduzido inclusive a métodos que usavam jogos de sorte como o lançar de dados: a implicação clara disto é que os padrões melódicos e harmônicos do padrão de oito compassos se tornaram tão estandartizados que arranjos arbitrários podiam ser feitos sem problemas de incongruência (vide Ratner, 1970), a despeito da sofisticação que ele assumiu formalmente em alguns compositores." (Groove Dictionaire, Minuet)

O jogo é, no conceito da arte, o momento pelo qual ela se eleva diretamente acima da imediatidade da práxis e dos seus fins. O sistema técnico tonal compreendia um corte determinado no campo de tessitura e estabelecia regras próprias e autônomas para o jogo de composição com notas. Assim como o jogo, a arte passa a se definir como um espaço-tempo de organização e regramento interno, cuja significação se limitava a seu próprio jogar, tocar, brincar. A estandartização do sistema tonal possibilitava que suas convenções fossem ordenadas ao acaso, como mero fazer material. A arte como jogo seria como um autômato de probabilidade.

\footnotetext{
${ }^{11}$ Hanslick, Do Belo Musical, Ed. Unicamp.

${ }^{12}$ Huizinga, Homo Ludens, perspectiva.
} 
Adorno, crítico dos extremos, protesta: "quando a arte é inteiramente jogo nada resta de expressão" (Adorno, TE, paraliponema, pág 349). Assim, certo de que a arte não é mero jogo de formas caleidoscópicas e técnicas, Adorno aponta que, no pensamento sobre a técnica, é essencial distingui-la do conteúdo, questão essa que permite também entender mais precisamente o que é o progresso no interior da arte, já que ele não pode ser apenas o progresso da técnica.

Crítica do progresso - Primeiramente é necessário reconhecer que o progresso na arte não é qualitativo de imediato. Se por um lado o progresso dos meios técnicos e da racionalização é inegável, por outro comparar uma obra com outra com termos "melhor do que" se inseriria em uma espécie de loquacidade cultural vazia. As obras não se ligam umas às outras conforme sua qualidade; são incomensuráveis. Conforme afirma Adorno só se comunicam, "antiteticamente: "uma obra é inimiga da outra"” (ADORNO, TE, p. 238), ou seja, as obras só se comparam de maneira que se possa reconhecer como elas recolocam problemas técnicos e expressivos das obras do passado. Adorno esclarece ao afirmar que a polifonia de Bach, sua "estrutura subcutânea", só poderia aparecer claramente diante de uma palheta orquestral que ele ainda não tinha a disposição, realização que Webern levaria a cabo tanto com seu arranjo orquestral da Oferenda Musical, quanto com o contraponto em suas obras. No entanto, o filósofo pondera que reivindicar a perspectiva em um quadro medieval seria destruir sua expressividade. "Os progressos são ultrapassáveis pelo progresso" (ADORNO, TE, p. 238).

Para compreender o que Adorno tem em mente é preciso reconhecer que seu pensamento dialético tem em vista diretamente o recurso das obras vanguardistas do século XX às técnicas herdadas do passado. Quando no século passado nos deparamos com as harmonias cromáticas de Gesualdo, as politonalidades stravinskyanas de Heinrich Biber, o contraponto bachiano de Schoenberg e a polirritmia africana de Reich e Ligeti, uma profunda transformação do modo de ver o progresso da história da música se enuncia. O uso de materiais regressivos não impede a arte de manifestar muitas vezes conteúdos verdadeiros e progressivos no interior da história:

“O próprio domínio progressista do material obtém-se às vezes mediante a perda do domínio do material. O conhecimento preciso das músicas exóticas, outrora rejeitadas como primitivas, mostra que a polifonia e a racionalização da música ocidental - as duas 
são entre si inseparáveis -, que lhe conferem toda a sua riqueza e toda a sua profundidade, neutralizam o poder de diferenciação presente nas mínimas variações rítmicas e melódicas da monodia; a rigidez da música exótica, monótona para os ouvidos europeus, foi manifestamente a condição daquela diferenciação.” (adorno, TE, 238)

O domínio das técnicas e maneiras do passado, quando recolocado em problemas composicionais do presente decorre de um movimento de consciência e espiritualização, e não de um plano de autenticidade do material do passado. Trata-se de um uso subjetivo de um material disposto objetivamente, que desperta para a capacidade de um outro possível, daquela diferenciação por hora rejeitada, que certamente é, nas palavras de Adorno, uma maneira da arte tornar-se assim "mais livre para protestar contra o próprio domínio do material" (TE, 239). O domínio do material por sua vez implica uma espiritualização, mas quando isso se realiza, no interior das obras, o espirito é colocado em perigo novamente diante de um inteiramente Outro que vêm à tona. A racionalidade instrumental violenta visa ocultar e reprimir esse conteúdo expressivo indefinido. Este conteúdo indefinido é justamente o que faz com que as obras se projetem para um outro futuro, uma linguagem do por vir, que em seu progresso, no entanto, não deixa de cobrar um preço diante de sua ruptura com o presente. $\mathrm{O}$ efeito inovador de Rameau abre portas para o futuro e sela a decadência convencional do seu tempo presente. O progresso na arte não deixa ileso o passado; a sua libertação cobra o seu preço. "O prix du progrés é inerente ao próprio progresso" (adorno, te, 239)

Quando o progresso galopante no século XX fez com que explodisse o estilo obrigatório, convencionado no âmbito da técnica tonal, tornou-se latente a sensação de contingência no que diz respeito aos critérios de autenticidade e verdade, dos procedimentos técnicos e de sua expressão. A validade da obra enquanto obra expressiva se viu ameaçada pela tempestade do progresso. Se atentarmos para a polissemia das obras no século XX vemos que cada uma parece querer criar seu próprio mundo, sua própria linguagem, rompendo com os estilos universais e as técnicas obrigatórias. Jorge de Almeida é preciso ao ler esta questão tendo em vista a reflexão de Adorno:

“A 'obrigatoriedade' das formas e tipos impostos por determinado estilo histórico submetia, assim, o artista individual e a obra singular a seu poder universalizante. O termo Stilgebundenheit [compromisso de estilo] designa, portanto, 
algo muito mais forte do que um compromisso estilístico assumido livremente; referese, antes, às enormes dificuldades para o rompimento efetivo com normas e práticas artísticas herdadas da tradição.” (Almeida, Critica dialética, 33)

É justamente a liberação desta obrigatoriedade do estilo e da técnica que enfraqueceram os critérios técnicos de avaliação da arte no século XX. Nos períodos obrigatórios, onde a técnica dominante imperava sob o estilo, como durante todo o período de vigência do sistema tonal, as obras eram avaliadas apenas mediante sua individuação, mediante a maneira expressiva que um ou outro compositor fazia uso da técnica. No século XX a situação é diametralmente oposta. A enxurrada de técnicas e estilos fez com que o único método de avaliação da arte fosse a inventividade da nova técnica, esta espécie de tecnocracia no âmbito da arte.

A crítica de Adorno, atenta a este cenário, não deixa de reafirmar diversas vezes que é preciso reconhecer que o progresso na arte não pode ser simplesmente o progresso de sua técnica:

\footnotetext{
"Em última análise, o progresso não é só um progresso do domínio do material e da espiritualização, mas também um progresso do espírito no sentido hegeliano, da consciência da sua liberdade. Pode discutir-se indefinidamente se o domínio do material em Beethoven é um progresso em relação ao de Bach; um e outro dominam perfeitamente o material segundo dimensões diferentes. A questão sobre qual dos dois é maior é ociosa; mas não a constatação de que a voz da maioridade do sujeito, emancipação do mito e reconciliação com este, portanto, o conteúdo de verdade, evoluiu mais em Beethoven do que em Bach.” (Adorno, TE, 239)
}

Como vemos, é a dimensão da consciência da liberdade que materializa o signo de algum progresso humano, e esta aparece em Adorno associada ao conteúdo de verdade. O conteúdo de verdade em Adorno, por sua vez, é claramente formulado nos termos do esclarecimento: emancipação do sujeito; emancipação e reconciliação com o mito e com a natureza. Que este conteúdo, por sua vez, só possa ser alcançado através da técnica não faz com que ele se limite ao progresso de sua autonomia e domínio sobre a natureza; é preciso reconhecer o que os une e o que os separa. A técnica é a constitutiva da arte, pois nela se resume todo o aspecto construtivo e produtivo do ser humano. A técnica possui caráter chave para o conhecimento da arte, pois só por meio dela é possível adentrar no interior das obras, analisá-las formalmente. A técnica é 
assim o ponto chave para determinar o momento racional e abstrato no interior do enigma das obras. Mas a técnica não é a totalidade da obra de arte, "perante o conteúdo, o aspecto técnico é apenas um entre outros" (adorno, TE, 240). O momento efêmero, o desvio, o impulso mimético, o lirismo são conteúdos da obra com os quais a técnica se relaciona de maneira dialética: os tenta dominar pelo tour de force. Se por um lado a técnica é a substância da linguagem musical, por outro ela "é idêntica e não idêntica ao seu conteúdo" (adorno, música e técnica, em I-III,233). Entender a técnica é assim também entender o momento expressivo, o mais que força a técnica ao seu limite, o subjetivo que deve ser objetivado no interior do discurso, o sentido da expressão que se organiza no interior da forma local e global:

“a estreita união de técnica e conteúdo, em oposição às convenções, é expressa pela afirmação de Beethoven de que muitos dos efeitos que comumente se atribuem ao génio natural do compositor são, na verdade, unicamente devidos ao emprego hábil do acorde de sétima diminuta; a dignidade de semelhante modéstia condena toda a loquacidade em torno da criação; só a objetividade de Beethoven presta justiça tanto à aparência estética como a evidência. A experiência das inconsonâncias entre a técnica, o que a obra de arte pretende, isto é, o seu estrato expressivo-mimético, e o seu conteúdo de verdade provoca por vezes revoltas contra a técnica" (adorno, TE, 243)

Vemos aqui, como em Rameau, a expressão musical se coadunando com a técnica. Sua verdade é a superação de um estado de conciliação com a aparência da convenção. A genialidade é o desvio da ordem naturalizada e a reconfiguração de seu sentido num plano ainda mais racional. Sua autonomia é seu direito de escolher, com consciência da liberdade, diferentes caminhos modulantes, revoltar-se contra a técnica. A superação e reconciliação com o mito é a manifestação de uma natureza segunda que se apresenta como possibilidade de uma submissão não-violenta. A indefinição e suspensão do fluxo temporal que um acorde diminuto polariza foi símbolo do poder expressivo do gesto musical no interior da linguagem tonal. Se é possível constatar este paradigma no âmbito do sistema tonal, a partir do século XX com a dissolução do sistema o problema torna-se muito mais complexo. A própria expressão genial dos acordes diminutos perde sua força frente à intensa modulação da música do fim do romantismo. A ruptura formal é levada ao extremo pelo expressionismo de Schoenberg e tal avanço no âmbito da técnica de manipulação harmônica cobra seu preço dificultando a elaboração de grandes trechos musicais que preservassem as categorias 
tradicionais da forma musical como direcionalidade, contraste, homeostase etc. Veremos no segundo capítulo desta dissertação mais precisamente como se deu este processo.

Assim apresentamos até aqui os principais temas que giram em torno do debate sobre a técnica visando dar destaque a crítica do progresso positivista desenvolvida por Adorno. Como vemos, o recurso à expressão mimética é fundamental nesta crítica e para esclarecê-la é preciso nos debruçar então sobre a compreensão do polo da expressão na música.

Expressão - Para compreender o conceito de expressão em Adorno faz-se necessário construir uma complexa constelação conceitual que envolve verbetes como impulso, mimese, linguagem, conteúdo e verdade. O conceito de expressão, assim como a maioria das categorias estéticas, se fecha a sua compreensão total e imediata; é rebelde diante da teoria que o tenta dominar. Por isso falar da expressão sempre exige que a linguagem conceitual se contorça para buscar aquilo que é fugidio na manifestação das obras. Se a técnica é por um lado o que pode ser mensurado, compreendido no âmbito de sua própria lógica e regramento, a expressão por ser ligada a elementos miméticos ou manifestações efêmeras vive na esfera da semelhança, da metáfora, do absurdo. Daí Adorno afirmar:

\footnotetext{
"o que é qualitativamente contrário ao conceito só com dificuldade se reduz ao seu conceito; mas a forma, na qual algo pode ser pensado, não é indiferente ao pensado. A expressão da arte deve interpretar-se filosóficohistoricamente como compromisso" (ADORNO, TE, 131)
}

Desta forma, compreender a expressão é buscar dar forma à manifestação de conteúdos de verdade no interior de acontecimentos estéticos mediados pelo ato de interpretação. O compromisso é com a certeza de que a delimitação da expressividade de uma obra sempre fracassará, sendo a verdade sempre um vetor de força no qual o enigma das obras é interpretado em vista de uma perspectiva histórica. O conceito não pode dar conta da totalidade do objeto, sempre haverá um resto não idêntico que força à autocrítica e à possibilidade de reorientação da teoria. No entanto o conceito de expressão tornou-se deveras popular e seu significado se multiplicou na esfera do senso comum. Como nos lembra Dahlhaus: 
“o conceito de expressão em virtude da erosão a que esteve sujeito como palavra-chave da estética de leigos, tornou-se tão ambíguo, vago e extenso que, para não ser inútil, se deve tornar mais preciso e muito mais restrito." (Dahlhaus, Estética musical, pág. 31).

Para dar conta de precisar o que afinal significa o conceito de expressão em Adorno vale dividi-lo nas três esferas de sua atuação, a saber, o ato composicional, o ato interpretativo de realização musical, e por fim, a manifestação da obra ela mesma. O conceito de expressão atua nestas três esferas de maneira distinta, mas não totalmente autônoma; falar de um destes momentos é também falar dos outros. Os impulsos e elementos expressivos no interior do processo composicional devem ser compreendidos pelo intérprete no momento da realização da obra. Não deixa de ser simbólico que o termo expressivo tenha se convertido em uma técnica interpretativa. Só ao final, na sua recepção e realização, a obra como um todo manifesta numa esfera mais abstrata seu conteúdo expressivo, sob a forma de um enigma e de um sentido.

Impulso - Na base do processo composicional, ao modo de Schoenberg, Adorno reconhece a necessidade da expressão. Esta se manifesta primeiramente naquilo que Adorno chama de impulso mimético. Trata-se de uma conjugação de dois complexos conceitos com amplo lastro histórico. A mimese é talvez o mais antigo conceito ligado à arte. Por imitação, grosso modo, se compreende a capacidade do homem de reconhecer e reproduzir objetos. Representação, reflexão, identidade, imitação da natureza fazem parte do repertório de conceitos em torno da categoria de mimese. No entanto a acepção de Adorno não se submete à tradição da compreensão do caráter mimético, trazendo à tona uma nova acepção do conceito:

“A mimese é na arte o pré-espiritual, o contrário do espírito e, por outro lado, aquilo a partir do qual ele se incendeia. Nas obras de arte, o espírito tornou-se seu princípio de construção, mas só satisfaz o seu telos onde se eleva a partir do que deve ser construído, dos impulsos miméticos, e nelas se integra em vez de se lhes impor de um modo autoritário. A forma unicamente objetiviza os impulsos individuais quando os segue para onde eles se dirigem por si mesmos. Apenas isto constitui a méthexis da obra de arte na reconciliação. A racionalidade das obras de arte só se torna espírito ao desaparecer no que lhe é diametralmente oposto. A divergência do construtivo e do mimético, a que nenhuma obra de arte se acomoda - por assim dizer, o pecado original do espírito estético - tem o seu correlato no elemento do desvario e do burlesco, que mesmo as mais importantes obras contêm em si; parte do significado que possuem consiste em camuflá-lo.”(ADORNO,TE,139) 
O que viria antes de qualquer operação de racionalização e justamente onde ela se funda é o locus onde vive a mimese no interior da arte. A arte técnica, construída, se realiza enquanto objetividade plena de sentido apenas quando é capaz de ir além de seus próprios processos construtivos. Se não dá conta de exprimir um mais, além de sua própria construção, decai em artefato. Ir além de sua pura espiritualização significa, por sua vez, ser capaz de manifestar a força contida no elemento mimético que impulsionou o artista à expressão. A mimese em Adorno é a fração da obra que deve ser mantida e superada de modo não violento.

Para compreender melhor o que Adorno entende por mimese nos esclarece Max Paddison em seu livro a respeito da estética musical de Adorno:

“'[adorno] usa o sentido de mimese para indicar um processo de 'adaptação à', de 'tornar alguém similar a um meio' onde 'a exterioridade serve de modelo para a interioridade'. (...) Isto quer dizer que a mimese pode ser entendida como uma forma de cópia, e de identidade, com o mundo exterior em direção à proteção diante do meio, no sentido de sobrevivência. Ela é a continuação da magia primitiva na arte, como 'identificação com o agressor' onde 'tornar-se semelhante com o inimigo geraria imunidade'." (PADDISON, Adorno Aesthetics of Music, pág 140.)

Como vimos acima, em nossa reflexão sobre a técnica a magia primitiva surgia como primeiro modo de dominação e racionalização da natureza. A mimese seria o impulso à identidade com o exterior, com fins de controle e superação da violência que o mundo externo exerce sobre uma vida. O termo oscila entre uma compreensão antropológica e psicológica da mimese, a qual Freud foi certamente um dos formuladores. Se atentarmos para as obras de Freud Totem e Tabu e Mais além do principio de prazer, a compreensão do significado deste impulso mimético em Adorno ganha profundidade:

“uma pulsão seria então um esforço, inerente ao orgânico vivo, de reprodução de um estado anterior que o vivo teve de resignar-se sobre a influência de forças perturbadoras externas; seria uma sorte de elasticidade orgânica, ou se quiser, a exteriorização da inércia na vida orgânica” (FREUD, Obras Completas, v. 18. Pag, 36)

Aquilo que é experiência da vida vem inevitavelmente acompanhada de seu oposto: a morte. A dor, a dissolução, as cicatrizes, os sofrimentos repetidos, as despedidas coexistem com a capacidade criativa, produtiva, reprodutiva, inventiva da energia vital movida pelo impulso, instinto de sobrevivência. Este instinto é marcado 
pela força da nostalgia aos estados regressivos da vida, seja a sensação oceânica do momento reprodutivo ou a tendência de retorno ao estado inorgânico. $\mathrm{O}$ instinto de sobrevivência é sempre permeado por esta utopia nostálgica do sentimento oceânico. Projeta a vida em direção a um estado de superação que é progresso da vida, mas também direção à dissolução. O conceito de Impulso [Trieb] é o próprio movimento de projeção, pulsão, pulso, quantum de força que impele os sujeitos à ação em vista de sua perpetuação perante a exterioridade. Esta força depende da identidade, do reconhecimento, e num plano superior, da espiritualização e dominação da natureza externa. É esta força que Adorno reconhece atuando na base do processo criativo.

A arte toma para si esta força expressiva, este impulso da interioridade em direção à objetividade, mas só o realiza quando o supera no interior da forma mesma. A arte seria mera funcionalidade mágica se se limitasse a expor estados instintivos dos sujeitos, no entanto, a estética de Adorno é capaz de reconhecer que na arte a manifestação da subjetividade dialeticamente se torna objetiva para surgir como segundo inobjetivo:

"A arte é plenamente expressiva quando, através dela, é subjetivamente mediatizado algo de objetivo: tristeza, energia, nostalgia. A expressão é o rosto plangente das obras. (...) Se a expressão fosse simples reduplicação do que é subjetivamente sentido, permaneceria inútil; a ironia do artista acerca de um produto que resulta da impressão, e não da invenção, sabe isso muito bem. Mais do que de tais sentimentos, o seu modelo é a expressão de coisas e situações extrartísticas. (...) Só que a expressão se torna duplamente enigmática porque o sedimentado, o sentido expresso, é novamente absurdo, história da natureza, para lá da qual nada conduz a não ser o que esse nada, na sua impotência, consegue exprimir. A arte é imitação unicamente enquanto imitação de uma expressão objetiva subtraída a toda a psicologia, expressão que talvez outrora o sensório percebia no mundo e que em nenhum lado subsiste senão nas obras. A arte fecha-se, mediante a expressão, ao ser-para-outro que avidamente a devora e fala em si: tal é o comportamento mimético da arte. A sua expressão é o contrário da expressão de alguma coisa.”(ADORNO, TE, p. 131)

Vemos com o pensamento de Adorno se esforça por determinar o conceito sem, no entanto, limitá-lo a nenhuma de suas facetas. Ao afirmar que a "arte é o rosto plangente das obras" quer apontar como o impulso mimético se manifesta no interior do processo criativo enquanto este é o material sobre o qual o espírito se incendeia, racionalizando e dominando a objetividade; de forma alguma é reprodução imediata do artista; o que chora na arte é o inobjetivo no interior da objetividade. O que é projeção do artista, impulso mimético, acaba por se abstrair naquilo que Adorno chama de 
comportamento enigmático da linguagem artística, ou seja, a expressão no interior da obra de arte sempre se manifesta como aquela que exige a decifração e devora ao mesmo tempo. Quando fala sobre si mesma a obra formula um sujeito em si mesma, sem recurso à exterioridade. O artista criador, ao projetar-se sobre a objetividade, acaba por dissolver-se na exterioridade; o que resta do artista é sua habilidade de dar forma ao impulso, segui-lo para onde ele quer ir na objetividade. Por sua vez o sujeito estético - o sujeito da obra - surge como a aparição de um segundo momento inobjetivo na obra, mas agora sem identidade mimética, ou seja, de maneira negativa; uma mimese nãoidêntica.

\footnotetext{
"Semelhante mimese é o ideal da arte, não o seu procedimento prático, nem também uma atitude dirigida para o caráter expressivo. A mímica que, no artista, liberta o expresso passa dele para a expressão; se o expresso se torna o conteúdo psíquico tangível do artista e a obra de arte sua cópia, a obra degenera em fotografia desfocada. A resignação de Schubert não tem o seu lugar na pretensa atmosfera da sua música, não no que sente como se a obra disso fosse a traição, mas no É assim que ela manifesta com o gesto do deixar-se cair: é a sua expressão. A substância da expressão é o caráter lingüístico da arte, fundamentalmente diverso da linguagem como seu médium." (ADORNO, TE,p. 132)
}

Mais uma vez Adorno visa apontar como se dá a relação entre a esfera da expressão do artista e a esfera da expressão da obra. O gesto é a marca das mãos do artista sobre o material, a figuração de um pensar corporal, que manifesta fisiognomicamente as pulsões internas do indivíduo. Na obra o gesto se torna uma abstração em segundo grau: abstrai da singularidade do sujeito produtor e manifesta a tensão perante a objetividade, torna-se um é assim, um mais, "um deixar cair" que na esfera da aparência estética só se apresenta por metáforas formais. Forma e conteúdo em tensão é o slogan da expressão. Só entre forma e conteúdo é que é possível reconhecer a linguagem da arte, e como lembra Adorno, não como meio de expressão de conteúdos, mas ao inverso, a própria expressão como linguagem.

Para nos debruçarmos sobre a concepção de linguagem musical de Adorno cabe uma pequena digressão a respeito da relação entre o pensamento de Adorno e Benjamin no que diz respeito à noção de linguagem. 
Linguagem muda - Rodrigo Duarte ${ }^{13}$ é preciso ao apontar como a concepção de expressão e linguagem de Adorno é próxima do pensamento de Benjamin no texto Sobre a Linguagem em Geral e sobre a linguagem do homem (2011). Assim como Adorno, Benjamin procura fazer jus a uma linguagem não comunicativa, ou seja, que não seria apenas suporte para a expressão de conteúdos. Para isso Benjamin parte da distinção entre linguagem das coisas e linguagem humana. Trata-se de uma concepção radical de linguagem, onde, abstratamente, absolutamente tudo participaria da vida do espírito:

“a existência da linguagem estende-se não apenas a todos os domínios de manifestação do espírito humano, ao qual, num sentido ou em outro, a língua sempre pertence, mas a absolutamente tudo. Não há evento ou coisa, tanto na natureza animada, quanto inanimada, que não tenha, de alguma maneira, participação na linguagem, pois é essencial a tudo comunicar seu conteúdo espiritual” (BENJAMIN, escritos sobre a linguagem, pág 50)

Trata-se claramente de uma interpretação metafísica da constituição linguística. Para Benjamin a essência linguística das coisas é sua própria linguagem, uma linguagem sem língua. $\mathrm{O}$ abismo entre a linguagem e a essência das coisas é onde se encontra a tensão que todo filosofar formula sua hipótese. A expressão das coisas só deve ser entendida, então, como sendo linguagem na sua mais intima essência, mesmo que para compreendê-la em sua abstração, tenhamos sempre que perguntar de que essência espiritual ela é a manifestação imediata. Tornar conteúdos essenciais imediatos é o símbolo da capacidade mimética e mágica no interior da linguagem:

"falar de magia da linguagem significa remeter a outro aspecto: a seu caráter infinito. Este é condicionado por seu caráter imediato. Pois precisamente por que nada se comunica através da língua, aquilo que se comunica na língua não pode ser limitado nem medido do exterior, e por isso em cada língua reside sua incomensurável, e única em seu gênero, infinitude.” (Idem, p. 54)

Enquanto que no domínio das coisas a linguagem manifesta imediatamente a infinitude de maneira abstrata, no âmbito do domínio humano da linguagem, a linguagem dos homens, a manifestação objetiva da linguagem se submete à palavra expressa na língua. A linguagem dos homens é aquela que nomeia, que emite a palavra

${ }^{13}$ DUARTE, R. Expressão Estética: Conceito e Desdobramentos, pág 85, em Mimese e Expressão, org. Duarte, R.; Figueiredo, V.. Ed. UMFG 2001. 
mágica para controlar o acontecimento. Mais precisa, plenamente comunicável e intensiva, a língua humana estabelece uma relação mimética com a linguagem das coisas em vista de sua dominação. A comunicabilidade intensiva da língua humana enquanto essência espiritual, no entanto, não passa imune a essência linguística abstrata da linguagem das coisas; ambas se interpenetram:

"no interior de toda configuração linguística reina o conflito do expresso e do exprimível com o inexprimível e a inexpressão. Ao considerar esse conflito, vislumbra-se na perspectiva do inexprimível, simultaneamente, a última essência espiritual.” (Idem, p. 59)

Para esclarecer que tipo de expressão daria conta de manifestar tal conflito linguístico no mundo - o inexprimível como última essência espiritual - Benjamin indica nada menos que o domínio do som. Assim, em contraposição a nomeação característica da linguagem humana:

“a linguagem mesma não se encontra expressa de modo perfeito nas coisas enquanto tais. (...) as línguas dos objetos são imperfeitas, e eles são mudos. Às coisas é negado o puro princípio formal da linguagem que é o som. (...) O que é incomparável na linguagem humana é que sua comunidade mágica com as coisas é imaterial e puramente espiritual, e disso o símbolo é o som. A bíblia exprime esse fato simbólico quando diz que Deus insuflou no homem o sopro: que é, ao mesmo tempo, vida e espírito e linguagem." (Idem, p. 59)

A diferenciação linguística que a metafísica de Benjamin opera entre linguagem das coisas e linguagem humana passa assim por duas facetas objetivas: som e nome. As coisas falam uma linguagem emudecida, que o homem nomeia e faz falar. $\mathrm{O}$ som, no entanto, é capaz de estabelecer uma comunidade mágica com a linguagem emudecida das coisas tornando o que seria pura objetividade em sopro imaterial e espiritual. Assim, sob a égide dominadora do homem, a natureza é forçada a mostrar seus signos e sinais. No entanto, a natureza sempre reivindicará sua mudez. De sua mudez, se lhe fosse dada uma língua, a natureza emanaria um canto triste:

"o lamento é a expressão mais indiferenciada, mais impotente da linguagem; ele contém quase que só o suspiro sensível; e basta o rumor da folhagem para que ressoe junto um lamento" (Idem, p. 70) 
Num tema caro à compreensão da música em Adorno - como aponta Jean Marie Gagnebin em uma nota de rodapé ${ }^{14}$ do trecho a seguir - a natureza manifestaria em forma de silêncio e luto a sua condição lamuriante e triste:

"Por ser muda, a natureza é triste e se enluta. Mas é a inversão dessa frase que penetra ainda mais fundo na essência da natureza: é a tristeza da natureza que emudece. Em todo luto, há uma profunda inclinação para a ausência de linguagem, o que é infinitamente mais do que uma incapacidade ou uma aversão a comunicar. Assim, aquilo que é triste sente-se conhecido de parte a parte pelo incognoscível.” (Idem, p. 70)

A ideia de uma tristeza essencial da natureza, do sofrimento como afeto fundador da linguagem, da ausência de língua verbal que dê conta de manifestar esse afeto é um tema comum no pensamento de Adorno e Benjamim, claramente marcados por resquícios da teologia judaica. A proximidade do pensamento dos dois filósofos quanto a este tema é verificável em afirmações como:

“A verdadeira linguagem da arte é sem palavras, o seu momento averbal tem a prioridade sobre o momento significativo do poema, momento que não se encontra totalmente ausente da música. Assim, um rinoceronte, animal mudo, parece dizer: sou um rinoceronte. O verso de Rilke - «Pois, não há lugar / que te não veja» -, que Benjamin tanto apreciava, codificou de um modo dificilmente superado a linguagem não significativa das obras de arte: a expressão é o olhar das obras de arte. A sua linguagem, na relação com a linguagem significativa, é algo de mais antigo, mas não recuperado: como se as obras de arte, ao modelarem-se pela sua estrutura sobre o sujeito, repetissem o modo do seu nascimento e da sua libertação.” (Adorno TE, pág 132).

Como vemos no trecho acima, Adorno não deixa de reconhecer nem o momento significativo e nem o momento a-verbal da arte. Que a arte fale muitas vezes por uma linguagem próxima da mudez do gesto e do movimento das formas não é surpreendente para um filósofo compositor que sempre se posicionou ao lado do debate formalista da música na esteira de Brahms e Schoenberg. Mas que especificamente a linguagem musical ainda possua uma significação e perpetue algo da mimese com a linguagem verbal é algo que a primeira vista pode soar contraditório. Para esclarecer esta possível contradição, feita esta primeira digressão a respeito do problema da

\footnotetext{
${ }^{14}$ Nota 31. "a ideia da tristeza da Natureza, presente neste ensaio e também na filosofia da música de Adorno, remete a um estado de luto da Natureza após a queda e o fim do Paraíso; portanto, a uma narrativa bíblica que serve de referência conceitual para devolver à Natureza uma dignidade ontológica subjetiva. Quando o homem, expulso do Paraíso, não consegue mais reconhecer, através do nome, a significação essencial e boa da Natureza, mas a transforma num objeto a ser dominado e explorado, a Natureza é condenada ao silêncio e ao luto. (N. da E.)"
} 
expressão e da linguagem em Benjamin, faremos uma leitura atenta do texto de Adorno Música, Linguagem e sua relação na composição atual publicado em sua versão final em 1956 para compreendermos as particularidas da concepção adorniana de linguagem musical. $^{15}$

Música e Linguagem - Para Adorno a música é e não é idêntica à linguagem; nas suas palavras a música é "semelhante" à linguagem. Semelhante significa estabelecer um regime diferenciado de identidade que não exclui a divergência nãoidêntica no interior do processo de designação, ou seja, ao se pensar as relações entre música e linguagem é preciso reconhecer suas semelhanças e suas diferenças. As semelhanças são reconhecidas imediatamente no uso partilhado de termos como idioma musical, entonação, pergunta e resposta, período, pontuação, frase. Também é possível estabelecer semelhanças no âmbito da lógica musical, que à maneira da relação entre as palavras possui operações de causa e consequência, subordinação, identidade e diferença. Talvez a semelhança mais marcante seja a sua ligação direta com o sopro da VOZ:

"a semelhança com a linguagem se estende desde o todo da textura organizada dos sons significantes, até o som singular, o tom como umbral da existência, o puro portador de expressão.” (ADORNO, Fragmento sobre musica e linguagem, p. 25.)

A voz como portadora da expressão é um tema caro a estética da música. ${ }^{16}$ Adorno afirma que o momento da inflexão verbal das palavras, a articulação dos sons no tempo, é um "momento onipresente na música". Como vimos acima, a unidade entre

${ }^{15}$ É digno de nota que o referido texto de Adorno mais uma vez expressa o compromisso do filósofo com a práxis composicional da época. Em clara oposição ao pensamento majoritário de compositores com Boulez e Schaeffer, Adorno pretende salvaguardar o aspecto linguístico da música que era diminuído pelo ímpeto tecnicista dos referidos artistas. Boulez pretendia fazer "tábula rasa" do passado e se engajava em compor estruturas e polifonias, se afastando de qualquer elemento mimético expressivo. Nos seus estudos de engenheiro de som Schaeffer afastava a música da esfera da linguagem afirmando que a música nada mais era que simplesmente uma disposição sonora no tempo, independente de articulações linguísticas. No entanto a crise é mais profunda; desde a superação do sistema tonal a linguagem musical entrou em crise com a perda de referencialidade universal e o isolamento de seu idioma entre especialistas. Vivemos uma babel entre especialistas.

16 Poderíamos encontrar um amplo lastro histórico de desmerecimento da música instrumental pelos pensadores da arte musical em favor da música vocal acompanhada da palavra. No entanto, a título de exemplo, apontaremos aqui apenas o caso de Rosseau que no famoso embate com Rameau defendia em seu livro sobre a Origem das Línguas o nascimento da linguagem enquanto unidade entre a expressão musical do lamento, da dor, da paixão e da palavra. "a paixão faz falar todos os órgão e confere à voz todo o seu brilho; assim, os versos, os cantos, da palavra, tem uma origem em comum." Cap. 12 prg. 1 . 
som e palavra, a capacidade de nomear sonoramente os objetos é passo fundador da linguagem humana e particularmente da linguagem musical. Talvez antes de adquirir capacidade de nomear, a linguagem humana se aproximasse da dos animais, próxima do puro som expressivo, onomatopeico, aliado ao gesto. É o impulso mimético que une no mesmo som o desejo de vida e de expressão. Mas como aponta Adorno, a semelhança com a linguagem vai além deste primeiro grito expressivo. É certo que, assim como a língua humana evoluiu em direção a formação de vocábulos, a linguagem musical também evoluiu em direção à capacidade de construir seus signos.

Isso fica claro no caminho que consolidou o sistema tonal. A evolução técnica desde o nascimento da polifonia no século XIV permitiu que a racionalização da música se desenvolvesse até o surgimento do stile rappresentativo no renascimento italiano com Monteverdi e Cacini, estilo este, que de maneira evidente, estabelecia um regime de representação e aparência diretamente ligado a elementos miméticos das palavras. A submissão da música à palavra - aqui no nascimento do estilo operístico - fazia com que a sua semelhança com a linguagem se acentuasse. Adorno aponta também o fator da invariância de motivos e padrões, que usados de maneira repetitiva no decorrer da história da música se sedimentaram e adquirem a feição de uma segunda natureza, ou seja, são históricos, mas devido ao seu uso reiterado se apresentam como naturais. Trata-se literalmente de um regime de aparência das convenções que se manifesta em cadências estereotipadas, acordes que representam funções determinadas, sequências melódicas e ornamentos. São esses signos, esses vocábulos, os responsáveis pela articulação formal em pequena e grande escala da composição musical. As cadências, por exemplo, encerram seções e partes da forma global das obras; são como os pontos ou o salto do parágrafo.

Mas na comparação com a linguagem significativa a música só pode ser chamada de linguagem de um modo totalmente diferente, e o que a diferencia radicalmente é sua proximidade com o aspecto teológico, que como vimos é tão caro a Benjamin:

“O que a ela [música] diz se encontra por sua vez determinado e oculta na pura afirmação. Sua ideia é a figura do Nome divino. É uma oração desmitologizada, liberada da magia da influência; é o intento humano, vão como sempre, de nomear o nome mesmo, em vez de comunicar significados.” (Idem, p. 26) 
Desta afirmação é possível reconhecer como Adorno se filia à tradição romântica de interpretação da música como manifestação do absoluto. A música pura, desprovida de relações imediatas e miméticas com objetos exteriores, seria aquela que fala apenas de si própria, linguagem sobre a própria linguagem, formas sonoras em movimento que expressam a sublimidade. No entanto, na acepção de Adorno a música seria uma linguagem que vai além da própria linguagem, uma espécie de transcendência que advém de seu próprio conteúdo e que aproximaria a manifestação musical do puro Nome inominável, linguagem das coisas. Dahlhaus é preciso ao comentar:

“a linguagem da teologia judaica, que Adorno corteja da poética e da teoria linguística de Walter Benjamin, poderia, de toda forma, ser transportada para uma metafísica dialética sem perda do significado, na qual um claro eco da estética romântica é audível, mas de modo que a entusiasmada "intimação da infinitude" é solapada pelo desapontamento diante do fato de que ninguém terá nada além de meras intimações." (DAHLHAUS, A ideia de Música absoluta, p. 115)

Com intenções intermitentes, meras intimações em direção à infinitude da linguagem sonora autônoma, Adorno pode marcar mais uma diferença entre a expressão musical e a linguagem conceitual denotativa:

“A linguagem significativa quis dizer o Absoluto através da mediação, e ele escapa em cada intenção singular, ocultando cada tentativa com sua limitação. A música o encontra de maneira imediata, mas no mesmo instante este escurece, do mesmo modo que uma luz muito forte cega os olhos, de maneira que o totalmente visível já não pode ser visto.” (ADORNO, fragmento sobre musica e linguagem, p. 28)

Desta forma Adorno estabelece e reconhece a dialética inerente à linguagem musical: ela é capaz de elaborar pinturas musicais, gestos miméticos expressivos, o rosto plangente das obras, mas mesmo quando é inexpressiva, quando é pura forma de expressão, faz falar algo de uma natureza muda, que violenta a capacidade de dominação da razão através da aparição sublime, que manifesta uma linguagem sem intenção, nome fantástico incomunicável.

Imagem não-imagética - Elaboramos até aqui um panorama geral da compreensão de Adorno a respeito dos conceitos de técnica e expressão. Mas para realmente lidarmos com a objetividade que a teoria crítica exige, apresentaremos a 
seguir uma análise do primeiro movimento da Sonata para Piano No. 26 em Mi bemol maior, Op. 81 de Beethoven. A análise desta peça se justifica no interior desta dissertação pelos seguintes motivos: primeiramente a obra é de grande afeição do filósofo Adorno, que afirma reconhece-la como uma "obra do mais alto nível”, "o modelo da metafísica de Beethoven" e faz referência à sonata em momentos centrais de seu pensamento, sendo possível encontrar citações e comentários em diversos trabalhos do autor; em segundo lugar esta Sonata, muitas vezes chamada de sonata característica, é uma sonata de programa, ou seja, cada movimento tem sobre si o signo de uma palavra o que nos permitirá apresentar a dialética da manifestação musical no que diz respeito à operação da linguagem; e por fim, como vimos na primeira parte deste capítulo, o elemento expressivo formalista é diretamente ligado a manifestações de ruptura no continuo harmônico, o que pretendemos mostrar em mais um exemplo.

A sonata foi escrita entre 1809 e 1810 e é fruto da encomenda de um mecenas, o Duque Rudolph. Com a invasão das tropas francesas de Napoleão em Viena o duque resolve fugir, retornando um ano depois. Metafóricamente retratando o ocorrido, a cada movimento Beethoven inscreveu um título programático: o adeus, a ausência e o retorno. O termo em alemão para o adeus - Lebewholl - tem um significado característico, pois literalmente seria traduzido como "viva bem", equivalente ao nosso "passe bem". Esta promessa de felicidade na despedida ficará notável no caráter geral da obra. No entanto, a respeito da característica programática da obra, Adorno não se apega a seus conteúdos extra musicais e é capaz de reconhecer seu verdadeiro conteúdo musical que filosoficamente ele pretende mediar:

"Sua simples e distinta configuração nos termos da música de programa já prove um impulso para a humanização extrema e para a subjetificação, como se atualmente para sermos humanos devêssemos ser capazes de ler a linguagem da trompa, do trote de cavalos, da batida do coração. A exterioridade que é sentido da interioridade" (ADORNO, Beethoven, p. 174)

Se atentarmos ao primeiro compasso - a introdução em adagio - é possível estabelecer a mediação com diversos temas aqui expostos. 
Figura 2 - compassos 1 e 2.

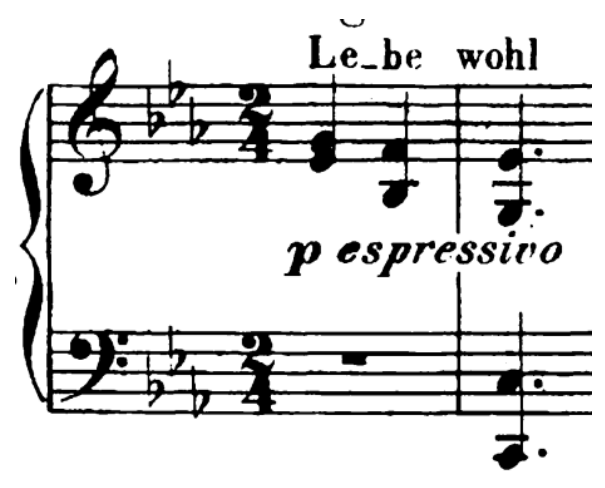

Sobre os três primeiros acordes Beethoven escreve o título da obra, como se ao interpretar, o nome ressoasse cantado interiormente pelo intérprete, como se fosse falado, reafirmando aquele momento onipresente em toda a música. O encaminhamento das vozes - grau conjunto na voz superior e arpejo na inferior - somada a tonalidade de Mi bemol maior remete diretamente a sonoridade das trompas, então chamadas de Trompas Francesas, que parecem soar não tão distantes, em surdina. A cadência inicial é uma cadencia deceptiva, cadência de engano, interrompida. Que dessas poucas notas se possa criar a sensação de expectativa, e esta não se resolva da maneira convencional, pode se depreender claramente uma função expressiva, uma subjetividade que se projeta e se vê colocada em cheque, desvio da convenção e da forma, impulso mimético que vai em direção ao não-idêntico. A frustração, que decorre de uma escuta historicamente constituída se manifesta na elaboração íntima do encaminhamento de voz, que exclui a sensível do acorde dominante, ou seja, mesmo sem aquela nota que seria a maior propulsora da expectativa tonal o impulso se mantém. Só quem foi educado culturalmente através das fórmulas invariantes do sistema tonal pode participar desta experiência singular, ou seja, a linguagem musical num primeiro momento jamais é universal. Esta experiência só é possível no interior do sistema, do idioma tonal, e seu desvio é na verdade sua marca mais determinante, a que mais intensamente se enuncia. Em sua primeira Sinfonia, Beethoven coloca lado a lado cadência perfeita seguida de cadencia interrompida. Já em sua fase madura da qual esta sonata se aproxima é possível reconhecer nesta escolha uma tendência hegemônica da harmonia romântica, em prorrogar as expectativas no tempo e romper com os clichês convencionais. Na sequência destes primeiros acordes Beethoven apresenta o segundo e terceiro material motívico: 
Figura 3 - compassos 2, 3 e 4.

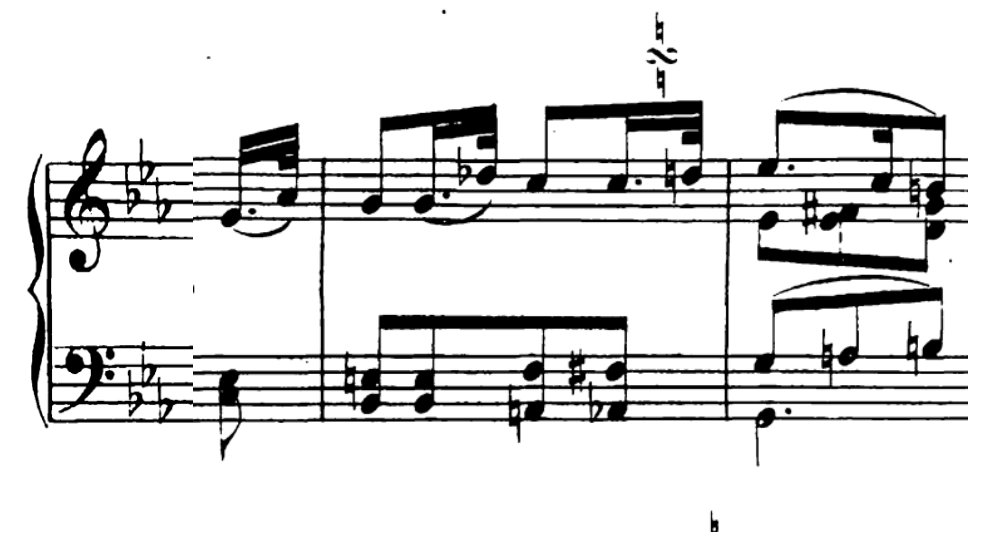

O ritmo da melodia guarda o pulso anacrúsico das "batidas do coração" e do "trotar dos cavalos" que reaparecerá em pintura sonora mais adiante. No acompanhamento é possível ver duas vozes antes unidas e próximas se distanciarem cromaticamente espelhadas em direção à oitava. Esse movimento de distanciamento progressivo da tessitura também servirá de motivo formal para toda a obra. O giro harmônico até a cadência imperfeita, que termina na tônica com baixo na terça, marcado pelo cromatismo do acompanhamento expõe aquele elemento "genial" de Beethoven, o acorde de sétima, no caso de sexta aumentada, ou sexta francesa, para manter a referência extramusical. Na sequência da resposta à melodia principal, Beethoven em poucos compassos já nos leva para um caminho mais distante, a região da mediântica:

Figura 4 - compassos 7-8.

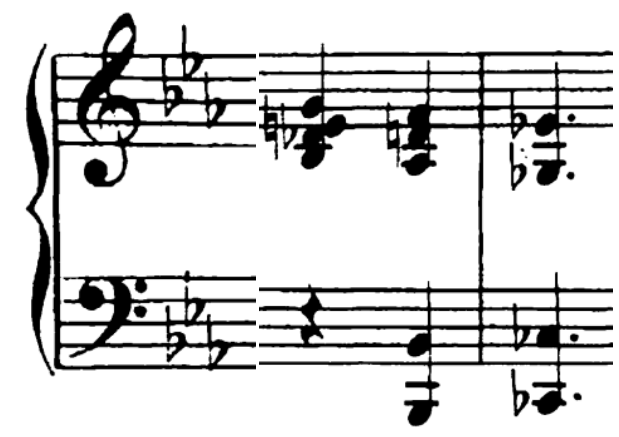

Fazendo uso do mesmo encaminhamento melódico da voz superior Beethoven re-harmoniza o trecho inserindo e com acordes diminutos e dominantes nos leva até a tonalidade mediântica de Dó Bemol maior. Conforme atesta Flo Menezes: 
"Todas [as mediantes], entretanto, mantêm o caráter de estranheza se incorporadas ao discurso tonal, pois são funções satélites estranhas ao tonalismo, verdadeiras "deturpações” ou alterações das funções relativas e anti-relativas. São, porém, de uma incrível riqueza, onde a relação de terças surge como grande opção informativa no processo de saturação do discurso da tonalidade!!!” (MENEZES, apoteose, pág. 16)

Essas verdadeiras deturpações, desvios absurdos, indicam mais uma vez a enorme carga expressiva da introdução da sonata. A introdução termina com a reafirmação da região da subdominante, Lá Bemol, que oscila entre o acorde maior e o acorde menor através de pequenos encadeamentos, fragmentos espaçados, o ágio, as pausas marcando intervalos de silêncio, que nos lançam na escuridão e no enigma sublime $^{17}$. Desta reticente introdução, do teor melancólico da distância e do adeus, Adorno então reconhece o surgimento de outra figura mimética:

“a transição para Lá maior [sic] é uma das mais maravilhosas alegorias da esperança em Beethoven. (...) A modulação transmite o irreal, o não-ser da esperança. Esperança é sempre segredo, porque nunca esta aí - ela é a categoria básica do misticismo e a mais alta categoria na metafísica de Beethoven. (...) a esperança é uma imagem não-imagética a qual é especificamente e diretamente transmitida pela música; isto é, ela é parte da linguagem musical.” (ADORNO, Beethoven, pág. 174)

A esperança como símbolo do desejo de que aquele que parte, regresse, e passe bem em sua ausência. A esperança é também nostalgia de retorno àquele estado perdido, estado oceânico. Esse momento metafísico se reafirmará na maravilhosa Coda que encerra o movimento. Até lá o Allegro segue os caminhos da forma sonata clássica. Vale notar, no entanto, que os elementos de transição entre as partes, codetas e pontes, já ganham uma extensão e profundidade notáveis, o que indica o tensionamento da forma tão característico do estilo tardio de Beethoven. ${ }^{18}$ Depois da reexposição do tema ao fim do desenvolvimento, vemos o trecho mais enigmático da obra, mais obscuro, e ao mesmo tempo, construtivamente claro:

Figura 5: compasso 181.

\footnotetext{
${ }^{17}$ Compassos de 12 até 16.

${ }^{18}$ Vide compasso 36 até a exposição do segundo tema sobre a dominante (compasso 50) ou então logo adiante no compasso 58 até 69 formado por duas codettas.
} 


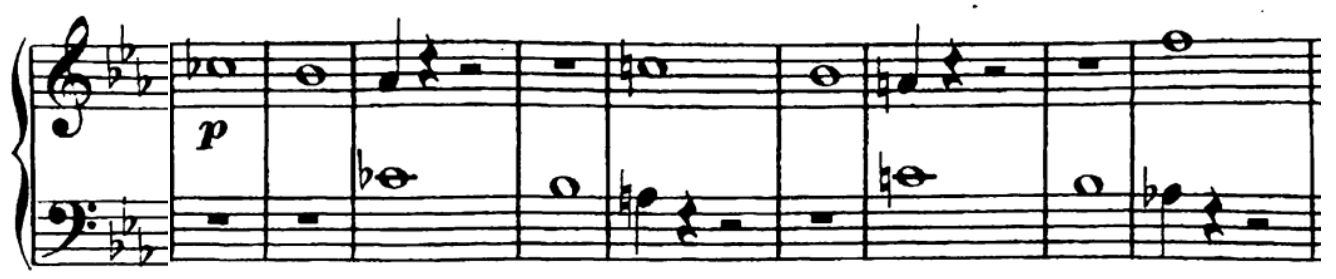

n...

Neste trecho que introduz a Coda vemos o mesmo motivo inicial da sonata agora esvaziado de sua harmonia. O motivo apresenta-se como pura série descendente por grau conjunto, modificado cromaticamente e intercalado de maneira canônica em torno do Si bemol dominante. A sensação de dissolução, de obscuridade é exatamente a contrária da integração orgânica que liga este trecho a célula máter que deu impulso a toda a forma. Adorno reconhece este elemento como elemento de desintegração da aparência estética:

“A integração extrema é extrema só na aparência e isso provoca a sua modificação: os artistas que a levam a cabo mobilizam, desde o último Beethoven, a desintegração.” (ADORNO, TE, p. 59)

Como veremos em nosso próximo capítulo o impulso à dissolução do eu, à desintegração da subjetividade, em paralelo com a força de construção é o motor da modernidade estética característica do século XX. Mas Beethoven nos traz na sequência destas obscuras notas um chamado à mudança de 'tom'. A Coda reafirma a esperança: "Muitos compassos de Beethoven ressoam como a frase extraída das Afinidades Eletivas: «Como uma estrela, a esperança desce do céu». (ADORNO, TE, p. 213)”. E no interior deste espaço harmonicamente estável e equilibrado, que parece nos mergulhar em uma plenitude, eis que surge novamente uma figura mimética enigmática:

Figura 6: compasso 240.

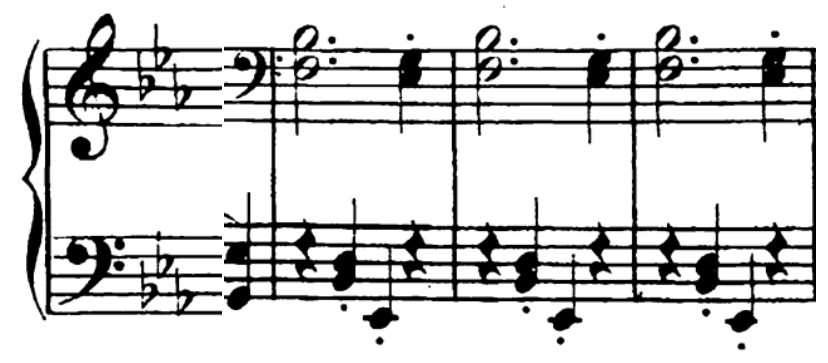


Neste trecho, durante estes três compassos imita-se o trotar dos cavalos, uma mimese obscura, pintura sonora. Nas palavras de Adorno:

"quando de maneira aparente o galopar dos cavalos torna-se audível como "sentido", esta passagem, que é mais sublime do que as palavras podem dizer, diz a mais transitória coisa, o som inefável da desaparição, e recupera a esperança do retorno, que jamais pode se afastar de qualquer reflexão sobre a origem e a essência da busca pela forma sonora." (ADORNO, da relação música e filosofia, p. 141)

A promessa de felicidade da arte se desenha e se esfumaça. Por ser pura promessa sabe do seu fracasso. Por ser objetividade ativa nos concede o direito à utopia. O elemento expressivo, que carrega o sentido no interior da forma, aqui manifesta mais uma vez sua exigência de verdade que é tanto forma quanto conteúdo. Se há algo que é essencial à arte temporal é a reafirmação da transitoriedade, da tendência à dissolução, à desintegração característica de toda matéria. Do rio que tudo arrasta até os caminhos de Heráclito a música manifesta a efemeridade caótica do tempo. A subjetividade em contato com este elemento transitório se vê compelida a reconhecer criticamente os limites da sua capacidade de designação ostensiva dos conceitos. Diante do informal, a subjetividade encontra seu conteúdo de verdade, e o faz no interior de seu aspecto temporal como memória, expectativa e instante.

Que a arte seja o corretivo do pensamento instrumental é uma ideia que podemos chamar de adorniana. Enquanto compositor engajado na práxis musical do século XX Adorno insistirá na força deste elemento estético como engajamento ativo no interior da sociedade, sem cair em um positivismo que crê na onipotência da arte perante a ordem do mundo; a arte deve fracassar para se realizar; uma mensagem numa garrafa jogada ao mar. Trata-se de reconhecer na arte o elemento não-idêntico de maneira não violenta, de forma que a racionalidade possa se reorientar em direção a uma reconciliação tanto com a natureza interna como externa.

Elaboramos até aqui um primeiro contato com as reflexões de Adorno tendo como foco sua reflexão conceitual tardia entre os conceitos de expressão e técnica. Dando sequência a esta dissertação passaremos agora ao cortejo das intervenções de Adorno na década de 50 e 60. 


\section{2 - Envelhecimento da nova música}

Obra, tempo e aparência - Para apresentar a reflexão de Adorno no pós-guerra faz-se necessário expor um panorama resumido do debate estético e artístico no texto Filosofia da Nova Música (1949). Concebido como excurso à Dialética do Esclarecimento, a Filosofia da Nova Música traça os impasses da razão ocidental no interior dos acontecimentos musicais e sociais mais relevantes do início do século. Partindo dos problemas sociológicos postos pelo Ensaio Sobre o Fetichismo na Música, Adorno elabora primeiramente o ensaio sobre Schoenberg, voltando-se particularmente para o domínio da produção mais avançada, que, nas suas palavras, é o único que manifesta verdadeiramente a situação da própria música em geral. A dialética de Adorno aponta como a arte mais avançada, autoconsciente e progressista, portava em seu interior a imagem daquilo que ela mesma se opõe. A obra de Schoenberg podia ser analisada como um pêndulo oscilando entre a superação da expressão convencional e o apelo por uma ordem autônoma e coesa. A desatada necessidade de expressar ideias novas e verdadeiras, e o peso da tradição, das formas e da inteligibilidade da escuta, apresentam na obra de Schoenberg as antinomias que a arte engendrava diante da sociedade heterônoma. Por outro lado era preciso fazer jus ao seu oposto que se materializava na obra se Stravinsky. Pois este, na sua constante evocação do passado, tratava também de apresentar uma faceta importante da constituição da subjetividade moderna. Pela sua distância com os materiais, pela objetificação da história, Stravinsky 
expunha o problema do indivíduo lesado, do mascaramento da impossibilidade da expressão subjetiva, uma postura que Adorno não temia considerar como regressiva.

Para tanto Adorno apresenta em sua introdução a seguinte afirmação que justifica a escolha dos dois compositores no interior do cenário da música em geral:

“A natureza desta música está impressa unicamente nos extremos e só eles permitem reconhecer seu conteúdo de verdade. "O caminho do meio", lê-se no Prefácio às Sátiras para coro de Schoenberg, "é o único que não leva a Roma"”. (ADORNO, FNM, p.13)

Apontar os extremos de uma constelação é a melhor maneira de apresentar os contornos de uma ideia que se pretende representação universal de uma situação. Os extremos esclarecem os objetos e tornam-se modelos exemplares para o pensamento. "o empírico será tanto mais profundamente apreendido quanto mais claramente for visto como algo de extremo. O conceito procede de algo extremo" (BENJAMIN, 2011, p. 23). O foco nos extremos de uma constelação de objetos teve por sua vez seu lastro empírico real. Adorno em suas reflexões busca sempre a mediação e o reconhecimento dos extremos e aprendeu isso também com os movimentos estéticos de sua época, como fica evidente neste trecho:

"Que a arte não deve reduzir-se à polaridade indiscutível do mimético e do construtivo como a uma fórmula invariante reconhece-se pelo facto de que, de outro modo, a obra de arte de qualidade deveria oscilar entre os dois princípios. Mas, na arte moderna, foi frutuoso o que se dirigiu para um dos extremos, não o que ficou no meio; quem se esforçasse por realizar a síntese entre os dois seria recompensado por um consenso suspeito." (ADORNO, TE, p. 58)

Para nos determos brevemente sobre os extremos apontados acima elaboraremos nossa leitura a respeito da atuação das vanguardas estéticas no início do século a partir de três conceitos que Adorno apresenta na Filosofia da Nova Música perante a obra de Schoenberg: "Um golpe alcança a obra, o tempo e a aparência." (FNM, pág. 39) Numa crítica que poderia ser estendida para outras artes com suas particularidades, é possível reconhecer este golpe sendo operado pelas mais diversas correntes estéticas do século XX. Para apresentar este panorama vejamos primeiramente o que se tem em vista com os conceitos tradicionais de obra, aparência estética e temporalidade musical. 
Dahlhaus é esclarecedor ao apontar as principais facetas da ideia de obra de $\operatorname{arte}^{19}$. O conceito de obra de arte era auto-evidente até o século XX quando entra em declínio diante da crítica da aparência operada pelas vanguardas. A ideia obra de arte seria aquela do todo orgânico fechado em si mesmo, autônomo, nascido com a invenção da escrita musical e consolidado no século XVI. Diretamente ligada à instituição social da sala de concerto burguesa, a ideia de obra de arte musical se manifestava também na capacidade da escuta estrutural e da perduração da obra na história. O reconhecimento das partes da obra no interior do desenvolvimento temporal era uma de suas características dominantes, sendo a recapitulação nas formas binárias a sua consumação. A obra verdadeira seria aquela que unificaria em sua aparência tanto o universal quanto o particular, na disposição de suas regras e lógica interna. A lógica da construção, convencionada sob a égide de leis e formas, gêneros e estilos obrigatórios, fazia da ideia de obra um campo restrito de atuação inventiva, donde seus elementos deviam ser compostos de maneira harmônica e homeostática, e mesmo o particular expressivo devia ser submisso ao universal. Um bom modo de compreender a ideia tradicional de obra é atentar para seu caráter orgânico.

As relações entre arte e natureza são profundas e amplas, mas o conceito de obra orgânica talvez seja o de maior lastro histórico. Para esclarecer essa ideia de organicidade vale remeter diretamente à Goethe que em A Metamorfose das Plantas afirmava:

"Se repararmos que é possível desta maneira que as plantas deem um passo para trás e que invertam a ordem do crescimento, tanto mais atenção havemos de ter ao caminho regular da Natureza, e, assim, chegamos a conhecer as leis da metamorfose, pelas quais ela produz uma parte através da outra e apresenta as partes mais diferentes pela modificação de um único órgão.” (GOETHE, Metamorfose das Plantas. p. 37)

A dimensão de unidade avistada por Goethe na natureza foi tomada como modelo. A arte mais bela e verdadeira seria a que reproduzisse a forma geradora do órgão originário. A razão dominadora da natureza deveria ser capaz de imitar seus processos de transmutação e superá-la em seu caráter de artefato histórico. Com o motivo gerador da forma e da variação, a metamorfose da obra de arte se daria em torno de um processo constante de repetição e diferença. Se atentarmos para o trecho a

${ }^{19}$ DAHLHAUS, K. Plea for a Romantic category: the concept of the work of art in the newest music. In Schoenberg and the New Music. Cambridge Press. 1987. 
respeito do conceito de obra na Teoria da Vanguarda de Bürger ${ }^{20}$ encontramos de maneira resumida a definição clássica do orgânico:

“A obra de arte orgânica aparece como obra da natureza. (...) A obra de arte orgânica procura tornar irreconhecível seu caráter de objeto produzido. (...) A obra de arte orgânica intenciona uma impressão unitária. $\mathrm{Na}$ medida em que apenas possuem significado em relação ao todo da obra, seus momentos individuais, individualmente percebidos, apontam sempre para esse todo” (BÜRGER, Teoria da Vanguarda, p. 147)

As obras de arte tradicionais eram construídas a partir desta relação sintagmática onde as partes individuais e o todo formavam uma unidade dialética, ao modo da metamorfose da natureza. A compreensão das obras e sua recepção dependeria daquilo que Bürger chamaria de "círculo hermenêutico", ou seja, uma compreensão que se movesse da parte para o todo e do todo para a parte. Bürger aponta como esta relação entre a obra de arte e a natureza - como, por exemplo, vimos na justificação dos acordes de Rameau - tornou-se uma aparição fantasmática. A obra de arte bela seria a representação das divinas proporções naturais materializada pelo gênio natural. Enquanto totalmente fabricada a obra devia aparecer como totalmente natural.

Para dar conta desta identidade, a razão dominadora, sob a égide do cálculo e da abstração, fez por naturalizar esse regime de aparência também no âmbito dos próprios materiais, para além da forma e função geral da obra. Para Adorno, no caso da arte musical, o idioma construído em torno do sistema tonal manifestava-se no fim do século XIX também como fantasmagoria, ou seja, a dimensão da aparência estética era elevada a aparição mística e fetichista: "As obras de arte apagavam os vestígios da sua produção. O seu caráter de aparência reforçou-se até se tornar o seu caráter absoluto.” (ADORNO, TE, 121).

A enorme carga de convencionalismos cumulava naquilo que poderemos chamar de esgotamento das possibilidades expressivas do sistema tonal. Trata-se de um esgotamento tanto de suas possibilidades técnicas - o âmbito da elaboração da forma e do material - como também do esgotamento das possibilidades expressivas, sob a égide da relação entre música e linguagem manifesta na relação com o drama e a representação. Seja no esgotamento das possibilidades modulatórias e da "invenção" de

\footnotetext{
${ }^{20}$ BÜRGER, P., Teoria da Vanguarda, Trad. Antunes, P.F., Ed. Cosacnaify, 2008.
} 
acordes, o sistema tonal se dirigia a um regime de saturação. $\mathrm{O}$ cromatismo e as modulações mediânticas trataram de solapar a unidade polarizadora do tom. Por outro lado a música "expressiva" ocidental, desde a consolidação do idioma tonal no século XVII, assumiu para si a possibilidade de manifestar a mimese de maneira totalmente aparente. Com a consolidação de um regime de imitação de afetos pelo trato da dissonância ou pela simples submissão da música à palavra, a arte musical encontrava sentido em seu fazer enquanto aparição destes elementos. Por sua invariância sob a égide do gênero e do estilo, este idioma histórico foi então adotado de maneira reificada, ou seja, naturalizada e enrijecida:

“Desde Monteverdi e até Verdi, a música dramática, como verdadeira música ficta, apresentava a expressão como expressão estilizada, mediada, ou seja, como aparência das paixões” (ADORNO, FNM, p. 39).

A crítica do ocultamento do momento produtivo e a naturalização de um processo histórico insere a leitura adorniana na tradição marxista de crítica do fetichismo, conforme nos mostra Safatle:

"Sabemos que um dos processos fundamentais presentes no fetichismo da mercadoria diz respeito à impossibilidade de o sujeito apreender a estrutura social de determinação do valor dos objetos, devido a um regime de fascinação pela "objetividade fantasmática" daquilo que aparece, fascinação vinculada à naturalização de significações socialmente determinadas." (Safatle, Fetichismo e mimesis na filosofia da música adorniana, em Discurso n37.ed. Alameda p. 380)

Desta forma é possível reconhecer tal regime de consolidação de uma objetividade fantasmática tanto nos elementos construtivos quanto nos expressivos. A coisificação do idioma tonal fundava-se na crença de que elementos sedimentados historicamente em fórmulas convencionais deviam ser empregados a partir de uma necessidade intrínseca de um de determinado caso particular. Estes elementos de invariância, que se apresentavam naturalizados, tiveram por sua vez no interior da história uma função bastante viva. $\mathrm{Na}$ organização da forma, elementos como o período melódico, a sessão das partes formais, pergunta e resposta, antecedente e consequente foram responsáveis pela organização do sentido temporal das obras. Quando os compositores do fim do romantismo se viram compelidos a elaborar formas cada vez mais alargadas não deixavam de manifestar o desejo de romper com os elementos de invariância. Para 
compreender como isso se dá no interior da forma musical é preciso entender como funciona a temporalidade musical.

A organização do tempo na música é diretamente relacionada com seu caráter de obra e de aparência. Vimos como a ideia de obra como total fabricado buscava assemelhar-se da ideia de natureza. No caso da arte musical, arte temporal por excelência, a ideia de obra como totalmente acabado e fechado em si mesma entra em contradição com seu caráter processual e efêmero; a música tende à desaparição no tempo sob a forma do silêncio. Por isso sua autonomia foi diretamente dependente de sua fixação enquanto texto em mais uma aproximação com a linguagem. O texto como suporte da obra musical abriu a possibilidade para a composição autônoma, racionalizada e abstrata, que visava, através da criação de um campo espacial de disposição de signos notacionais a elaboração de uma virtualidade que só se manifestaria mediante a realização da execução musical.

Não deixa de ser significativo que algo da espacialidade tenha de se estabelecer para elaboração da forma temporal autônoma. A forma musical é dependente de uma espacialidade, mas de uma espacialidade abstrata que se aproxima do efeito da duração, enquanto construção e justaposição de períodos e sessões musicais no tempo que se relacionam entre si. Assim para fugir das formas puramente improvisativas e apegadas à efemeridade do tempo natural, a música elaborou construtos que buscavam gerar sentido temporal através de elementos unitários de repetição que visavam dar conta do elemento metamorfoseante e diluidor do tempo. Somente com a repetição do que já se passou, com a persistência do idêntico, era possível afirmar a unidade da obra sobre si mesma. Como quem sabe que o fluxo temporal tudo arrasta, transforma e dissolve, a repetição na música visa reestabelecer a identidade diante do não-idêntico temporal que lhe é imanente.

O conceito de clássico de equilíbrio na forma é definido por esta relação paradoxal onde o continum musico-temporal resiste à modificação constante pelo método da variação e das formas repetitivas, mas só é capaz de expressar este paradoxo mediante a limitação do não-idêntico perante o idêntico; daí o tamanho restrito do desenvolvimento na música do período clássico. Que depois de Beethoven o tamanho do desenvolvimento tenha se expandido até a desagregação da forma é o símbolo de uma expansão do principio expressivo em conflito com as possibilidades e restrições construtivas da forma. As forças impetradas em direção ao momento expressivo, momento onde o fluxo temporal irrompe o contínuo musical, se expandiram até a 
destruição completa da ordem temporal classicista rompendo com a referida aparência de harmonia da forma. Assim, é preciso reconhecer antes como esta reivindicação de unidade temporal pelas formas repetitivas não é uma exigência plena da linguagem, e sim, mais uma aparência naturalizada:

“a relação da música ao tempo musical formal determina-se simplesmente na relação do acontecimento musical concreto com o tempo. Sem dúvida, durante muito tempo prevaleceu o facto de que a música deveria organizar sugestivamente a sequência intra-temporal dos seus fenômenos: deixar que um acontecimento decorra de outro de um modo que permita tão pouca reversibilidade como o próprio tempo. Mas, a necessidade desta sequência temporal, conformemente ao tempo, nunca foi verbal, mas fictícia, participação no caráter de aparência da arte.” (ADORNO, TE, p. 35)

Como apontamos acima, a ideia de obra totalmente integrada segundo o modelo da natureza apresentava-se como fantasmagoria de uma totalidade; o regime de aparência estética no âmbito das convenções se solidificava em uma segunda natureza estilizada e desgastada; e por fim a temporalidade clássica exigia um tempo dominado donde o elemento efêmero se submetesse a totalidade da forma sob o ideal do equilíbrio e da harmonia. Atentando a estes elementos constitutivos da arte musical tradicional vimos como o caráter de aparência naturalizada dominava a manifestação estética como um todo. Adorno reconhecerá então como principal vetor das vanguardas do século XX justamente uma "rebelião contra a aparência", uma rebelião contra o regime de apropriação fantasmática do conteúdo formal das obras.

O futurismo e Stravinsky - De fato, se atentarmos para a grande diversidade de manifestações estéticas do século passado muitas delas coincidem na crítica da obra tradicional, no apego pela nova expressão e na mudança nos paradigmas de compreensão espaço temporais da experiência estética. Esse golpe no aspecto temporal de aparência e da própria obra como um todo pode ser constatado tanto nos artistas que se dirigiram ao pólo extremo da técnica quanto aos que se dirigiram ao extremo da expressão.

A intensa industrialização e maquinazação do cotidiano ao fim do século XIX teve seu correlato nas manifestações estéticas do período. Tendo em vista a ruptura com a estética romântica, diversos movimentos artísticos incorporaram elementos técnicos oriundos do modo de produção industrial. Peter Bürger no Teoria da 
Vanguarda é preciso ao reconhecer como os movimentos artísticos da primeira metade do século XX operaram uma crítica às categorias tradicionais da obra de arte forçando sua reconfiguração pelo uso dos objetos fabris:

"Quando Duchamp assina um objeto qualquer, produzido em série, e o envia a exposições de arte, essa provocação pressupõe um conceito do que seja a arte. $\mathrm{O}$ fato de Duchamp assinar os ready-made guarda uma clara referência à categoria de obra. (...) desta forma, a idéia da natureza da arte, assim como ela se formou desde o Renascimento - como criação individual de obras únicas -, é questionada em tom de provocação; o próprio ato da provocação assume o lugar da obra.” (BÜRGER, Teoria da Vanguarda, p.

De imediato os Futuristas são o exemplo mais acabado desta tendência. Em seu manifesto A Arte do Ruídos, Russolo não esconde seu maravilhamento com o mundo das máquinas:

"Incitamos pois os jovens musicistas geniais e audazes a observar com contínua atenção todos os ruídos, afim de compreender os vários ritmos que os compõem, o seu tom principal e os secundários. Comparando depois os vários timbres dos ruídos com os timbre dos sons, estarão convencidos do quão os primeiros são mais numerosos que os segundos. Isto nos propiciará não somente a compreensão, mas também gosto e paixão pelos ruídos. A nossa sensibilidade multiplicada, após ter sido conquistada pelos olhos futuristas, terá finalmente ouvidos futuristas. Assim os motores e as máquinas das nossas cidades industriais poderão um dia ser sabidamente entoados, de modo a fazer de cada oficina uma inebriante orquestra de ruídos." (RUSSOLO, L. A Arte dos Ruídos, in Música Eletroacústica - História e Estéticas . org. Menezes, Flo. Edusp. 2009)

O ímpeto de dominação da natureza sonora torna-se tão claro quanto voraz. Russolo aponta que a esfera do sonoro, com sua magia originária, fez com que, desde os povos mais primitivos, a música fosse entendida como esfera divina, separada da vida ordinária ruidosa e dissonante. A tendência à dissonância no âmbito da música moderna seria por sua vez uma tendência à elaboração do "som-ruído". Assim, Russolo via como um progresso a incorporação no interior da obra musical de sons advindos da esfera da vida, pois estes rompiam com a aparência "tediosa" da música tradicional. A obra futurista rompia o campo semântico fechado sobre si mesma e se dirigia diretamente à esfera da vida. Mas Russolo não se limita a uma mera imitação e reprodução dos sons ruidosos do cotidiano, ele os quer dominar. "Nós queremos entoar e regular harmônica e ritmicamente estes variadíssimos ruídos” (idem, pág 53). Trata-se 
da fascinação de Russolo pelos novos sons que sob a égide da dominação e do controle artístico levaria a "enriquecermos os homens de uma voluptuosidade insuspeitável".

A crença positivista de que a dominação técnica ampliada da esfera sonora levaria o homem a uma "sensibilidade multiplicada", no entanto, mostrou-se historicamente falsa. O fascínio pela máquina e pelo ruído desembocou na verdade em uma profunda dessensibilização. Quando uma bomba explode ao lado de um homem, quando um ônibus rosna o motor nos ouvidos do povo, certamente não se fica mais sensível à humanidade. $\mathrm{O}$ ruído constante daqueles que vivem à porta dos viadutos devora a atividade de concentração, destrói a audição. As armas sônicas são o exemplo da dominação violenta das potencialidades do ruído. Tudo se assemelha ao vagabundo de Chaplin que é consumido pelas engrenagens da máquina. A técnica que seria libertadora e voluptuosamente poderosa torna-se a mesma que escraviza e submete todos ao ensurdecimento e à privação do silêncio. Nas cidades cada vez mais as pessoas ouvem música acompanhadas de ruído constante e de outras atividades. A reprodutibilidade técnica da música com isso também contribuiu. A escuta dos ruídos certamente permite a ampliação da fantasia sonora do compositor, mas dialeticamente reflete um estado das coisas onde o ruído polui a atividade estética.

Mas para além desta crítica sociológica do ambiente sonoro moderno que inspirava os Futuristas, o que nos importa aqui é o impulso tecnicizante que domina amplamente a esfera da ação humana. No caso da música ele é claramente reconhecido numa espécie de fixação fetichista e tecnicista pelo domínio sonoro. $\mathrm{O}$ apego à objetividade tem em si a possibilidade de abrir os campos do saber cientifico sobre o efeito acústico, mas também é facilmente transformado num fascínio pelos novos ruídos, pelas novas sonoridades timbrísticas dos instrumentos, para além da real constituição estética da obra.

O maquinismo latente nos Futuristas é encontrado em diversas outras manifestações estéticas do século XX. Podemos citar a Parade de Erik Satie que envolvia o uso de pistolas, sirenes e máquinas de escrever. Satie tem um papel peculiar no interior deste debate a respeito da ruptura com a ideia tradicional de obra. Depois que a escuta atenta e estrutural da obra de arte se consolidou nas salas de concerto do XIX, a escuta desatenta só era tolerada no âmbito das situações funcionais como ritos e festas. Quando Satie escreve música para ser ouvida como música ambiente opera um ataque à constituição fantasmática da obra de arte e a seu consumo fetichista. Mais uma vez a obra de arte se abre para a esfera da vida ordinária, do tempo vivido e assim opera 
uma critica negativa a sua feição tradicional. Se por um lado a crítica é válida e precisa, por outro ela é o pressuposto da prática da escuta desatenta propagandeada pela indústria cultural com suas mercadorias de entretenimento. A atitude de denúncia tornase conciliadora e premonitória de um problema cada vez mais grave em nossa sociedade: a desatenção participa da desubjetivisação do sujeitos. Os sujeitos modernos são cada vez mais reduzidos a engrenagens e submetidos às condições ideológicas e materiais da sociedade sem autonomia.

A resposta de Satie à acusação de Debussy de que sua música não tinha forma aponta, por sua vez, para uma saída muito comum no século XX: o descompromisso. Em resposta a Debussy, Satie escreve a peça "música em forma de pera" com tom de provocação, ironia e desprezo à crítica do compositor e amigo. A “obra” em nada difere das formas simples e estáticas de Satie, sendo apenas o seu título uma espécie de pseudo-crítica. Esse regime de auto-ironia, de distanciamento e indiferença aos problemas estéticos se configura como uma das críticas às obras de arte tradicionais, que exigiam seriedade no pensamento estético, mas por sua vez o faz de forma puramente regressiva e infantilista, como quem nega uma tradição e se conforma com o riso diante da catástrofe que esta mesma tradição ainda provoca. O pathos melancólico de Satie aponta para a situação geral de decadência diante da tradição. Neste cenário de mecanização, objetificação e conflito com a tradição nos debruçaremos brevemente sobre aquele que é certamente um dos maiores compositores do século passado: Igor Stravinski.

Stravinski é certamente um compositor da objetividade técnica, manipulador da tradição e um ironista. Sua estética anti-subjetiva fica latente em afirmações como:

“considero a música, por sua essência, incapaz de expressar coisa alguma: um sentimento, uma atitude, um estado psicológico, um fenômeno da natureza, etc. A expressão nunca foi uma propriedade imanente da música.” (STRAVINSKI, Poétique Musicale, Paris, 1952. P.18)

A alergia à expressão de Stravinski manifesta seu anti-romantismo e sua adesão ao formalismo. Seu objetivismo fica ainda mais latente na equiparação que faz de si mesmo como mero artesão medieval, que trabalha, ordena e fabrica a partir dos materiais que tem a sua disposição:

“A proibição do pathos na expressão prejudica a própria espontaneidade da composição: o sujeito que agora musicalmente nada tem a dizer de si mesmo, deixa assim 
de 'produzir' em sentido próprio e se contenta com o eco vazio da linguagem musical objetiva, que já não é sua. Segundo Rudolf Kolish, a obra de Stravinski é, principalmente, sobretudo na fase infantil, mas na verdade em seu conjunto, "música ao quadrado"" (ADORNO, FNM, pág 149)

A distância, no entanto, do que Stravinski afirmava e o que suas obras manifestavam é apontada, não sem ironia, por Boulez:

“as declarações contínuas sobre a incapacidade da música expressar algo, o desejo de se referir constantemente à abstração, à construção em si, ao jogo de formas, não seriam uma espécie de reação de respeito face a uma serie de obras que não foram capazes senão de "expressar", e do modo mais extremado?" (BOULEZ, Apontamentos de Aprendiz, p. 21)

Pois as obras da fase russa de Stravinski Les Noces, Sacre, Petrushka,Soldado etc. são apoiadas diretamente em textos e elementos exteriores, distantes da música pura $^{21}$. As cisões na consciência de Stravinski deixaram suas marcas em seu percurso composicional. Stravinsky compõe predominantemente de maneira distanciada, como quem opera máquinas em vista de certos produtos, fazendo música ao quadrado. No intenso movimento humanista que decorre do iluminismo até os dias de hoje, o acesso às técnicas do passado se ampliou de maneira exponencial. O compositor do início do século XX pela primeira vez tinha as facilidades de ter acesso à história da música e à música do mundo. Essa ampliação do horizonte permitia aos compositores encontrar elementos de culturas tradicionais ou mesmo de práticas históricas da música ocidental que operariam uma crítica às formas estandardizadas da música romântica. No interior deste cenário Stravinsky se mostrou o artista mais flexível praticando os mais diversos estilos composicionais. A radicalidade arcaica das obras da fase russa contrasta como o conservadorismo da fase neoclássica, e por sua vez, a fase dodecafônica surge como uma espécie de resignação ao fim da vida. De toda forma, Stravinski nunca rompeu com o conceito tradicional de obra de arte ao modo dos dadaístas e futuristas e sua a fase neoclássica é uma verdadeira apologia à obra tradicional.

Mas Stravinsky tem seu momento de crítica ao conceito de obra de arte em vista de seu objetivismo. Adorno faz uma leitura psicanalítica da obra de Stravinsky apontando como essas oscilações refletem o comportamento esquizofrênico. A ruptura

21 Adorno aponta como principais figuras expressivas em Stravinsky o grotesco, o arcaico, o infantil. Sobre o grotesco em Stravinski Vide ADORNO, FNM, pág 123. Sobre o arcaico vide Idem, pág 116. Sobre o infantilismo vide Idem, pág. 132. 
com a ideia de obra tradicional surge no interior desta manifestação patológica já contida nas obras da fase russa:

"Na fase infantil, o elemento esquizofrênico torna-se quase temático. A Histoire du Soldat acolhe, em suas configurações, modos musicais de comportamento psicopático. A unidade orgânico-estética fica dissociada.” (ADORNO, FNM, p. 135)

A coleção de estilos contida em uma mesma obra como no Soldat levava a música ao quadrado à crítica das formas tradicionais através da forma paródica, que mediante distorções do tonalismo, imitava para ridicularizar. "sua música tem permanentemente presente outra música, que "deforma", mediante a superiluminação de seus rasgos rígidos e mecânicos” (idem, p. 141) O elemento de shock operado pelos deslocamentos rítmicos e a justaposição de estratos colorísticos rompiam com a unidade orgânica da obra de arte tradicional. Na fase russa com o ímpeto de superar com a aparência naturalizada do sistema tonal Stravinski faz uso de uma série de procedimentos de desestabilização do idioma tonal como apogiaturas não resolvidas, superposição de tonalidade e acordes, cromatismo vertical. O emprego destes procedimentos de ruptura se dá sob estruturas classicamente tonais: as melodias de Stravinski são invariavelmente diatónicas ou de modos defectivos. Por trás da aparência de ruptura o compositor mantém notas centrais donde decorrem ocultas as tradicionais funções de tônica, dominante e subdominante ${ }^{22}$ : “em Stravinski, modernismo e arcaísmo são dois aspectos do mesmo fenômeno" (ADORNO, FNM, pág 124)

O objetivismo de Stravinski é notável e simbólico em seu ballet Petrushka (1910). A genial obra de Stravinski rompe com o realismo através do recurso ao clown da comédia del'arte; o uso de estruturas de sobreposição politonal rompem com o caráter de aparência fetichizada dos materiais tonais. Stravinski opera como um verdadeiro artesão que sobrepõe, por exemplo, no trecho inicial do solo introspectivo ${ }^{23}$ do palhaço um acorde de dó maior com um acorde de fá sustenido maior, o que solapa a funcionalidade de ambos os acordes transformando-os em sonoridade colorística. Adorno então vê no procedimento politonal a ligação direta com o impressionismo:

“a harmonia [em Stravinski] está muito perto do que o Grupo dos Seis, após a Primeira Guerra Mundial, chamava de politonalidade. O modelo impressionista da

\footnotetext{
22 Vide BOULEZ, P. Stravinsky Permanece, in Apontamentos de aprendiz. Pág 77.

${ }^{23}$ Seção 51 da partitura orquestral.
} 
politonalidade é o soar simultâneo de músicas espacialmente separadas na praça da feira." (ADORNO, FNM, pág 120)

Adorno elabora sua crítica lembrando então da cena inicial do ballet Petrushka que se passa numa feira russa. $O$ cenário da feira no interior do ballet nos remete diretamente ao espaço da cidade imaginária do futurista Russolo: uma profusão de fragmentos sonoros justapostos em uma paisagem musical. É simbólico que a música seja representada no interior deste cenário por duas máquinas musicais: o carrossel e o realejo. A figuração destas máquinas sonoras no interior da arte moderna permite Adorno reconhecer que o anti-subjetivismo de Stravinski incorre em uma aceitação da autoridade heterônoma da ação mecânica:

“As imagens da música mecânica produzem o shock de um modernismo já superado e caído no infantilismo. A música mecânica converte-se, como ocorre mais tarde nos surrealistas, na porta aberta para as irrupções do passado primitivo. O realejo, tal como se ouvia antes nas ruas, opera como déjà vu acústico, como reminiscência. Prontamente, como num passe de mágica, a imagem do gasto e decadente deve transformar-se num remédio contra a dissolução. É o fenômeno fundamental da operação espiritual levada a cabo por Stravinsky. Emprega o realejo como se fosse um órgão de Bach; e nisto seu humorismo metafísico pode referir-se à semelhança dos dois instrumentos como ao preço vital que os sons devem pagar para purificar-se das intenções. Toda a música até hoje teve de pagar a validez de vínculo coletivo com um ato de violência contra o sujeito, quer dizer, com a entronização como autoridade de um elemento mecânico" (ADORNO, FNM, pág 115)

A mecanização no âmbito dos materiais e da expressão servia de crítica ao sujeito romântico, mas dialeticamente essa crítica tornava-se realista ao ponto de mimetizar e reafirmar as condições opressoras da sociedade. A complacência diante do sacrifício da Sagração manifestava uma tendência à anestesia diante de toda a violência das guerras do século XX. A atomização dos sujeitos se via na atomização das melodias stravinskianas que perante o shock das oscilações rítmicas mimetizavam o corpo do homem dilacerado diante das forças da civilização técnica. A ausência de desenvolvimento dos materiais apontava para uma ruptura com o aspecto tradicional do desenvolvimento temporal na obra. Adorno é preciso ao reconhecer que o elemento temporal em Stravinsky decorre das operações elaboradas anteriormente por Debussy:

"Aquele que desde o Sacre foi aclamado como antipapa do impressionismo, aprendeu deste a "atemporalidade" musical. A quem quer que esteja formado na música 
alemã e austríaca é familiar já em Debussy uma sensação de decepcionada expectativa. (...) O ouvido deve orientar-se de maneira diferente para compreender exatamente Debussy, para entendê-lo, não como um processo de tensões e resoluções, mas como uma justaposição de cores e superfícies, como a de um quadro.” (ADORNO, FNM, pág. 144)

A pseudomorfose em pintura da temporalidade musical é um diagnóstico que Adorno reconhece em diversas manifestações estéticas. A justaposição de texturas e campos sem relação de causa e consequência, sem desenvolvimento, é notável em diversas obras de Debussy. Não é a toa que o gênero do prelúdio foi amplamente utilizado por Debussy. Como se a temporalidade em Debussy sempre tivesse um caráter de preâmbulo, mas a este, nada se segue. Tal efeito foi possível com a anulação das forças harmônicas em torno do modalismo ou da desfuncionalização harmônica:

Tecnicamente torna isso possível, em primeiro lugar, o que Kurt Westphal definiu como harmonia "privada de funções". Ao invés de expressar tensões de graus harmônicos no interior da própria tonalidade ou por meio de modulações, desprendemse de vez em quando complexos harmônicos estáticos em si mesmos e permutáveis no tempo. (ADORNO, FNM, p. 144)

Através de acordes desfuncionalizados ou da simples justaposição de complexos polimodais e cromáticos a música surge como puro ser imediato. A crítica da temporalidade em Adorno aqui encontra seu cerne: trata-se de reconhecer como elemento de libertação da música o seu aspecto de transcendência, do acontecimento que se espera de um desenvolvimento. $\mathrm{O}$ instante não pode ser entendido como mera facticidade, pois a lei da irreversibilidade do tempo o faz perecer a todo momento em algo distinto do que ele era. Por isso o instante na música sempre aponta para algo mais além de si mesmo. Mas o que ocorre com as repetições no interior das seções da música de Stravinski que se assemelham por sua vez ao tempo circular e estático do mito? Segundo Adorno a música sempre foi irmã e inimiga do mito:

"Desde que existe, a música tem sido um protesto, por mais que impotente, contra o mito e o destino perene, contra a morte mesma. Não se desprende de sua essência antimitológica nem quando um estado de desespero objetivo torna-se o seu próprio assunto. Nem a música garante o ser do outro, nem pode o som deixar de prometê-lo. A liberdade mesma lhe é imanentemente necessária. Essa é sua essência dialética."(ADORNO, Quasi una Fantasia, Stravinsky Uma imagem dialética, OC, pág 396)

Indiferente a este aspecto da liberdade musical Stravinski reafirma o desespero objetivo, um refúgio na imediatez. Adorno vê nesse regime de aparência de estaticidade 
uma ilusão positivista do progresso. As obras de Stravinski parecem convidar o ouvinte a esquecer da dimensão temporal, não exigem isso. Dahlhaus lembra que fazer o tempo estático foi sempre um foco do pensamento composicional de Stravinski. A ideia de parar o tempo; uma ideia que se manifesta num ritmo flutuante que provavelmente Stravinsky buscou nos compositores da ars nova medieval ${ }^{24}$. A questão da temporalidade em Stravinsky pode ser pensada então mediante as categorias bergosonianas de tempo espaço e tempo duração. O tempo espaço como tempo mesurado, nas palavras de Boulez, tempo estriado composto por uma sucessão de instantes justapostos e o tempo duração como tempo subjetivo, tempo liso, que envolve a transcendência da rememoração e da projeção. Transposto para o fato musical Adorno indica duas maneiras de se ouvir a música: a expressivo-dinâmica e a ritmo-espacial. $\mathrm{O}$ primeiro teria como modelo as inflexões agógicas do canto, com suas nuances expressivas que, por exemplo, no interior da melodia projetam a consciência para um outro além do instante. $\mathrm{O}$ segundo tipo de escuta tem como modelo o toque do tambor, baseado na divisão temporal em quantidades iguais que num plano virtual transforma o tempo em espaço. É certo que toda grande obra oscila entre esses dois modelos; a forma sonata elabora a dimensão expressivo dinâmica mediante a sua divisão em partes. A incorporação da dança no interior de sinfonias e sonatas manifesta o antípoda da temporalidade no interior da obra. "Estes dois modos de escutar música separam-se hoje diretamente e, separados um do outro, devem ambos ajustar contas com a não-verdade" (ADORNO, FNM, p. 153)

Mesmo com a crítica da aparência, da obra tradicional e de sua temporalidade Adorno vê em Stravinski o representante do aspecto conformista e ideológico da sociedade. Conforme afirmou Adorno em seu artigo de 1968 Stravinski - Uma imagem dialética incluído em Quasi una Fantasia, sua leitura da obra do mestre russo foi certamente a que gerou os maiores desentendimentos e leituras preconceituosas. A permanência de tal fato até os dias atuais provavelmente se deve a intensa positividade que se espalha pelos meios artísticos e ao desaparecimento da crítica. Os tempos atuais, intensamente regressivos, exigem dos artistas a conformação e a aceitação da arte como mero fazer, cada indivíduo isolado em sua estética. Era este o principal alvo da crítica de Adorno e sua verdade histórica permanece:

${ }^{24}$ DAHLHAUS, K. Problems of rhythm in the new music in Schoenberg and the new music. Cambridge University Press 1987. Pág. 52. 
"É unicamente tal positividade que se deve atacar em Stravinski, não sua habilidade artística, que é o que fundamenta sua preeminência diante de todos os seus apologetas. Mas o artisticamente hábil se comporta como verdade sem aparência, como um sentido que se abandona" (ADORNO, Stravinski in Quasi una Fantasia, OC - 16. P.400)

Schoenberg - Se nos detemos até aqui nas manifestações das vanguardas ditas regressivas da primeira metade do século apresentaremos a seguir de maneira resumida a leitura de Adorno a respeito de seus colegas de pensamento estético: Schoenberg, Berg e Webern. A Segunda Escola de Viena operou de maneira progressista a rebelião contra a ideia de obra tradicional, sua aparência e temporalidade. Façamos um breve panorama da experiência composicional daquele que pode ser considerado o maior compositor do século passado: Arnold Schoenberg.

A obra de Schoenberg enfrenta até hoje resistência em função principalmente das enormes reviravoltas que as diferentes fases na história da sua obra operaram, pois a cada novo passo Schoenberg apresentava criações totalmente inovadoras, enigmáticas, e o pensamento dominador se via imerso em um terreno movediço. Se a obra de Stravinski era vista por Adorno como de uma imagem dialética, já à obra de Schoenberg o filósofo adere o título de compositor dialético. A obra de Schoenberg parece oscilar como um pêndulo entre os extremos da manifestação artística: por vez sua obra se inspira em pinturas e textos literários, em outros momentos é do mais objetivo formalismo; num momento é totalmente temática, em outro atemática; aqui é fruto de uma torrente expressiva quase animal, ali é metalicamente construída e totalmente controlada ; por vez o contraponto e a polifonia se manifestam de maneira riquíssima, por outra a simplicidade e a subtração destroem a ornamental tradição polifônica. Essa polimorfia de sua obra simboliza o pensamento de um artista comprometido com a experimentação e com a evolução da arte; um artista que não se apega a suas próprias descobertas e segue o impulso inventivo durante toda sua vida:

"O sumo rigor é ao mesmo tempo a suma liberdade": a frase de George, o poeta a que a música de Schoenberg se impregnou da mais produtiva das contradições como lema de suas obras, apresenta um sentido que o leva muito mais além da estética classicista da qual procede e se converte em programa daquele novo modo de comportarse por parte do compositor que hoje modificou a música e talvez amanhã produza uma mudança da relação desta com a sociedade. Este sentido pode ser classificado de dialético. Em Schoenberg a contradição entre rigor e liberdade não se supera no milagre 
da forma. Converte-se em força produtiva. (ADORNO, OC 17, Escritos musicales IV, pág 214)

No interior deste movimento dialético nos debruçaremos fundamentalmente sobre o momento que Adorno mais valoriza na obra de Schoenberg: o momento expressionista .

Vimos acima como os movimentos vanguardistas da primeira metade do século XX buscaram romper com a aparência naturalizada da obra de arte tradicional. No caso do expressionismo de Schoenberg é possível reconhecer uma reconfiguração dos próprios conceitos em questão para além de sua crítica negativa. É neste sentido que podemos encontrar afirmações de Adorno como: "as únicas obras que hoje contam são aquelas que já não são obras" (ADORNO, FNM, p.34) e "a herança do expressionismo recai necessariamente em obras acabadas" (ADORNO, FNM, p.48). Trata-se da manifestação latente da contradição objetiva que as obras de arte encarnam em seu acontecimento histórico: são e não são.

A critica negativa fica imediatamente aparente quando visamos a superação do sistema tonal. Vimos em nosso primeiro capítulo como o movimento de domínio da técnica tinha seu correlato no âmbito da sociedade no interior da história, e que o progresso da técnica dizia respeito a sua relação com a verdade, estabelecida no interior das formas artísticas autônomas, ou seja, o progresso da arte dizia respeito à espiritualização diante dos dados sociais contidos de maneira autônoma nos seus procedimentos formais. É no interior de reflexões deste tipo que Adorno visa reconhecer o aspecto progressista da superação do sistema tonal em Schoenberg. A discussão sobre a possibilidade do uso de tríades ou não que dominará todo o século XX só pode ser entendida no interior de uma reflexão não imediatamente autônoma do fato musical. O desgaste do material é o desgaste de sua função no interior da sociedade como um todo. É por isso que para Adorno a perspectiva da música progressista envolve a capacidade de expressar algo verdadeiramente relevante perante uma situação histórica. Adorno aponta como o mesmo acorde de sétima diminuta que teve uma função expressiva determinante no sistema tonal agora surgia como falsidade, "mesquinhez e planura" no interior das peças de salão. Diante disto Adorno nos relembra que o desenvolvimento das técnicas no interior da história estabelece sempre domínios proibitivos com relação a certas práticas do passado: "na época do contraponto, sucessões de quintas estavam proibidas por serem consideradas uma espécie de regressão ao arcaico" (ADORNO, FNM, p. 36). Trata-se do processo de 
crítica imanente da história da música ocidental. Uma obra crítica a outra e supera a outra em si mesma reconhecendo no que é novo o que se ganha e o que se perde. Por isto a validade de uma obra no interior da história depende também dos caminhos que a história toma. O estado da técnica no presente é sempre o fator retrospectivo de avaliação da progressividade ou regressividade de uma obra. Nesta perspectiva crítica, é preciso sempre lembrar que o material musical - aqui no caso do acorde - é dependente da particularidade em que está inserido: "nenhum acorde é falso 'em si', pelos simples fato de que não existem acordes em si e por que cada acorde leva consigo o todo e até toda a sua história." (ADORNO, FNM, p. 38) Desta forma é preciso entender a liberdade do compositor de maneira dialética. $\mathrm{O}$ verdadeiro artista não opera com total liberdade como queria o sonho idealista, mas é confrontado com o peso da história a cada compasso; a música lhe exige e o material tem sua tendência: "Mas, para acomodar-se a tal obediência, o compositor tem necessidade de uma desobediência total, da maior independência e espontaneidade possíveis. Até esse ponto o movimento do material é dialético." (idem, p. 38) Desta forma é possível entender que no interior do sistema tonal o acorde de sétima diminuta cumpria uma função expressivo formal agora ele surgia desgastado. É frente a isso Schoenberg teve a coragem de superá-lo desobedecendo os princípios centrais da música tonal. No entanto o próprio Schoenberg aponta o que se supera e o que permanece:

\footnotetext{
“a coerência nas composições clássicas é baseada na unificação das qualidades de fatores estruturais como ritmo, motivos, frases, e a constante referencia de todas as melodias e acontecimentos harmônicos em direção ao centro de gravitação - A tônica. Renunciar ao poder unificador da tônica ainda mantém todos os outros fatores em operação." (SCHOENBERG, My evolution, Style and Idea, p. 49)
}

Ou seja, a relação de Schoenberg com as categorias históricas é sempre dialética, operando uma superação no interior das próprias categorias sem no entanto negá-las de maneira imediata. Essa transformação no interior das categorias fica latente quando atentamos a verdadeira revolução schoenberguiana do conceito de expressão.

Vimos como a concepção de expressão musical esteve até o romantismo ligada às práticas decorrentes da música ficta, como aparência de paixões. Tratava-se de um regime de mimese representativa calcado no âmbito de uma relação analógica entre linguagem e a técnica musical. A histórica do uso da dissonância que marca a origem do controle expressivo do sistema tonal chegava ao limite no século XX. É possível 
encontrar este limite nas primeiras obras de Schoenberg, onde o principio de ornamentação harmônica e as formas simétrico-extensivas ainda predominam a maneira de Brahms, Mahler e Wagner. Mas a revolução schoenberguiana veio na sua segunda fase comumente intitulada de expressionista. Tratou-se de uma mudança da qual o próprio Schoenberg indica como inconsciente, impulsiva. É diante de obras como Pierrot Lunaire, o opus 11 e o opus 19 que Adorno pode afirmar: "[Em Schoenberg], o único momento propriamente subversivo é a mudança de função da expressão musical" (ADORNO, FNM, p. 40) Pois em Schoenberg já não se trata de simular paixões mas antes registrar nas formas musicais os movimentos corporais inconscientes, os shocks, os traumas, o grito através da força da disposição imaginativa. Adorno fala também em manchas sonoras dando como exemplo o seguinte trecho do primeiro movimento das Pequenas peças para piano opus 19 de Schoenberg:

Figura

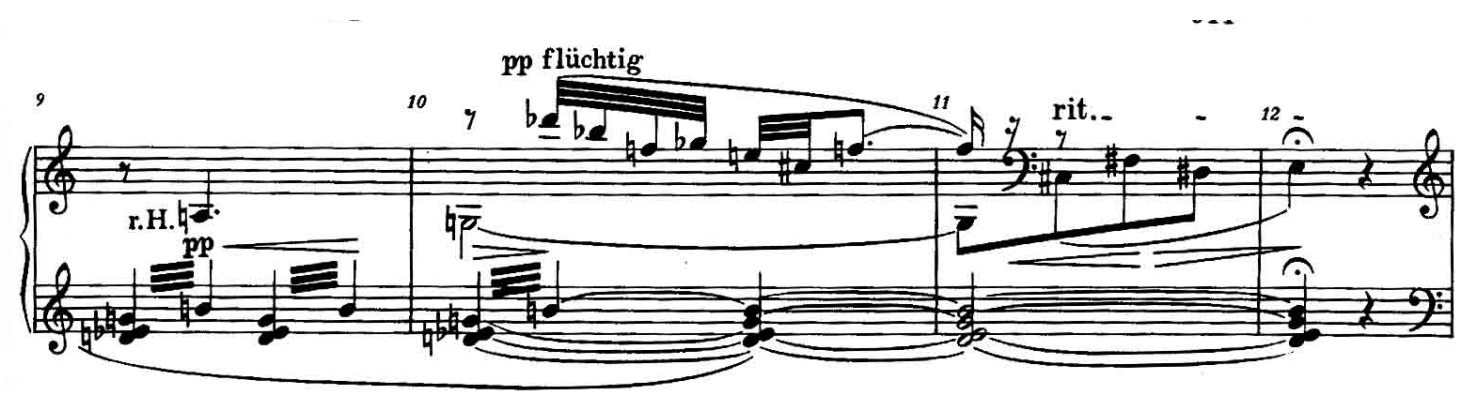

A mancha sonora causada pelo trêmulo seria um dos modelos de apresentação do momento expressivo no interior da forma musical schoenberguiana. Trata-se certamente de uma metamorfose musical em analogia à pintura, aos moldes do processo de Debussy, não fosse o modo concentradamente dinâmico que o trecho assume no interior da forma. A mancha que distorce o plano melódico e perturba a superfície aparente surge como exceção incluída na forma, como ruptura com sentido imediato da continuidade exigida pelas formas tradicionais. Se a aparência estética da obra tradicional exigia a mediação do universal, o expressionismo de Schoenberg libera o particular da subordinação à conciliação com o todo:

“A música de Schoenberg desmente a pretensão de que se concilie o universal e o particular. Já que esta música deve sua origem quase a um impulso vegetal, já que precisamente sua irregularidade se aproxima das formas orgânicas, não é de modo algum totalidade" (ADORNO, FNM, p.40) 
Desta maneira é possível constatar uma tendência à transformação do conceito de orgânico. Se no idealismo ele representava a unidade entre universal e particular a partir de Schoenberg, e poderíamos dizer da botânica moderna ${ }^{25}$, o conceito de orgânico se reconfigura para apresentar aquilo que é organizado, mas permite a manifestação do desvio e do informe. A tentativa de liberação plena das convenções apresentava uma natureza não mais velada pela unidade da forma. Nisso o impulso progressivo de superação se aproxima também daqueles elementos de regressão:

“O acorde dissonante não somente à consonância é o mais diferenciado e avançado, mas parece como se o princípio de ordem da civilização não o houvesse submetido totalmente, quase como se de certa forma fosse mais antigo do que a tonalidade. (...) O próprio progresso, com seu protesto contra as convenções, tem algo de infantil, de regressivo." (ADORNO, FNM, nota 6 da p. 41)

Esse elemento caótico, regressivo será um dos motivos expressivos mais frequentes no século XX. O recurso ao caos contra a tendência administração total do mundo moderno surge na arte como negação da ordem aparente. A natureza já não é mais ordem e sim desordem metamorfoseante.

$\mathrm{Na}$ obra schoenberguiana vale apontar mais um exemplo deste elemento inorgânico no interior da forma musical. Nas três peças para piano opus 11 vemos o principio expressivo se manifestar de maneira evidente. $\mathrm{O}$ primeiro movimento trás em si a estrutura bi-temática da sonata e sua exposição reflete a estrutura geral da obra num clássico ABA. No entanto depois de apresentados os materiais temáticos da peça temos no compasso 12 uma espécie de explosão, shock:

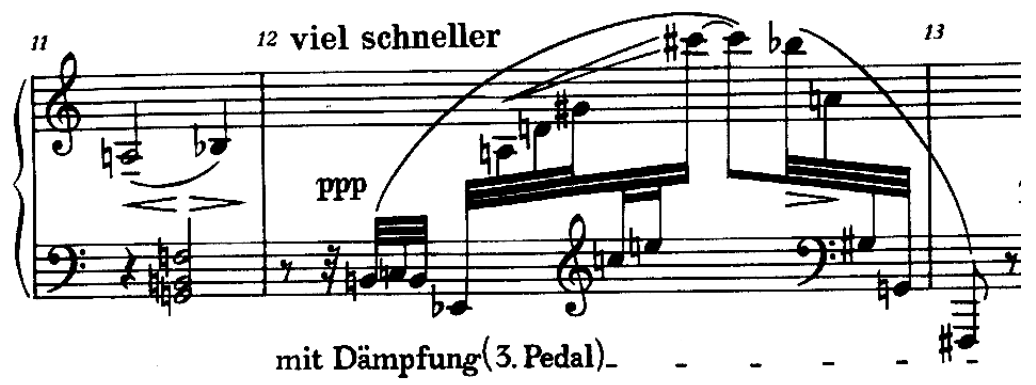

25 Seria relevante para aprofundar esta reflexão com uma aproximação, por exemplo, com o conceito de Rizoma de Gilles Deleuze manifesto em seu livro Mil Platôs. 
Se a apresentação temática guardava em seus contornos a clareza e a suavidade este elemento surge como ruptura no continuo temporal da peça. O shock que por um lado estremece o corpo mostrando que este ainda é vivo, por outro marca a sua decadência em petrificação, em fragmento. Mas o mais surpreendente é que este gesto de ruptura do primeiro movimento será o motivo que inspirará todo o terceiro movimento da peça:

“a última delas é uma única erupção exaustivamente composta, sem nenhum recordo de relações formais simétricas. O momento do abismal, do estritamente trepidante, que já antes ameaçava seriamente nos caracteres do scherzo de Schoenberg, o calmante de tipos herdados agora se desata do todo; um Adagio largo, mas agora constituído somente por contrastes ralos, não evolutivamente alinhavado, conduz a uma região do inconsciente que na música tradicional estava temerosamente envolta pelos véus da forma.“(ADORNO, OC 18, Escritos musicais V, p. 328)

Modelo de composição informal, este último movimento figura como o símbolo da liberdade criativa. Seu caráter fantástico e movediço, o uso de períodos contrastantes, a intensa oscilação temporal, seus fragmentos de rememoração do restante da obra e principalmente o final, com a dissolução fragmentária que lembra a imagem da desaparição, tornam este movimento um dos ápices da obra de Schoenberg.

Outra obra que não poderia passar ao largo desta resumida reflexão sobre Schoenberg é o seu Pierrot. Passados cem anos da estreia do Pierrô Lunar Op. 21 de Arnold Schöenberg ainda nos parece evidente a possibilidade de se afirmar que esta obra é também um ápice na obra de Schoenberg, e por que não, da história da música. Podemos dizer que devido a sua força interna é, até hoje, uma obra extremamente atual e de certa forma, ainda incompreendida. A obra permanece atual, pois seu antinaturalismo, sua expressão obscura e seu alto teor de inovação continuam a estimular fortuna crítica com alto teor de verdade, fator imprescindível em nossa sociedade marcada pelas exigências de clareza, realismo e ainda apegada aos padrões de escuta do sistema tonal. Desta forma Schoenberg permanece vivo.

Composto e apresentado no ano de 1912, em Berlim, esse ciclo de canções surge numa da onda vanguardista que ao lado outras grandes obras dos maestros da modernidade musical: no mesmo ano Debussy compõe Jogos (Jeuxs - Poeme Dance) e no ano seguinte é apresentada a Sagração da Primavera de Stravinsky. 
O Pierrô foi elaborado a partir de textos selecionados de um ciclo de cinquenta poemas de Albert Giraud intitulados Pierrot Lunaire. A versão de Schoenberg é por sua vez baseada na tradução de Otto Erich Hartleben, da qual o compositor recolheu e reorganizou três ciclos de sete poemas. Os poemas de Giraud, marcados pelo simbolismo dominante na literatura da época, foram elaborados na forma clássica do rondeau com a repetição dos versos iniciais no fim da segunda estrofe e no último verso da terceira e final estrofe. A recuperação da temática da Commedia dell'Arte, gênero do teatro italiano composto por bufonarias circenses e associado a questões políticas e morais da sociedade, vinha com o propósito de fazer frente à estética naturalista, portando a máscara do real e expondo-o como simples mascarada. Na leitura dos poemas é impossível não se lembrar de Baudelaire em $O$ vinho das famosas Flores do Mal, com a mistura que há neles da esfera fantástica de devaneios inebriantes de amor, violência e melancolia.

No âmbito da elaboração musical o tratamento de Schöenberg é de uma inovação que raras vezes se viu na história da arte. $\mathrm{O}$ fator que queremos dar destaque aqui é a transformação do estilo operístico: em contraposição tanto aos arroubos realistas e monumentais da ópera de Wagner e Verdi, quanto ao estilo vulgar "degustável" das operetas de cabaret. Schöenberg elabora uma música que funciona como anticanção. Para isso o compositor faz uso de um pequeno grupo de câmara de sete integrantes (flauta, clarinete, violino, cello e piano, cantora e regente). O Melodrama do Pierrô no entanto se expõe às avessas e, em sua lógica de fratura, se apresenta, ironicamente, como algo inautêntico para expor o autêntico.

Esse elemento de ruptura com o realismo se torna explícito quando lidamos com essa nova forma de cantar criada por Schöenberg: o Sprachegesang, canto-falar, falarcantando. No prefácio para o Pierrô, Schoenberg faz resumidamente os seguintes apontamentos para o intérprete: trata-se de uma voz-falada que conforme a variação das alturas notadas na partitura pode virar uma melodia-falada, mas jamais uma fala-cantada ao modo realista dos recitativos; nas palavras de Schoenberg "O que se pretende não é, de modo algum, uma fala realístico-natural." Desta forma o compositor elabora um enigma para o intérprete, o que cria um espaço de tensão entre a obra e sua execução. Através destas indicações, Schoenberg abriu o caminho para toda uma tradição crítica de reflexão sobre como interpretar o Sprechgesang, modelo que foi incorporado por diversas obras subsequentes ao Pierrô. O canto-falado rompia assim com os ares 
realistas da ópera e exigia do intérprete uma encenação estilizada própria do teatro bufo e da recitação.

A já referida inovação da tonalidade expandida, ou atonalidade, opera em algumas peças do Pierro uma espécie de inversão das tradicionais regras de contraponto: transforma as dissonâncias em notas de tempo forte e tolera consonâncias apenas como notas de passagem. A novidade no trato do material entra em tensão com formas clássicas de desenvolvimento musical como o canon, a fuga, e a passacaglia. Estruturada por estas formas autônomas, a relação da música com o texto oscila entre a independência do acompanhamento musical e a descritividade e inventividade nada vulgar de alguns trechos da obra, nos quais é possível reconhecer a pintura musical do texto. Quanto à especificidade deste e sua importância para a compreensão da música, vale lembrar que o próprio Schöenberg recomendava a tradução do texto para a língua local da execução. O texto, nesse caso, mais uma vez - como outrora na música antiga - ajudava a organizar o todo musical, tendo em vista a perda da unidade estrutural e formal que o rompimento com a tonalidade havia gerado e cujo sintoma manifestava-se na tendência miniaturista das obras de Schöenberg deste período.

Por sua vez, podemos ouvir novamente no Pierrô que em certos momentos a expressão musical se distancia do estilo representativo e mergulha no fluxo de ideias e motivos musicais que conjugam num só gesto invenção e sentimento para a forma. Adorno fala de uma música cuja imediatez já não adota a metáfora como referência, mas, sim, devora as imagens e permite que o interior mesmo se expresse. A conjugação deste ideal de expressão com a inversão dos procedimentos tradicionais da música estabeleceu os contornos deste estilo schöenberguiano que poderia ser mais uma vez intitulado de o compositor dos extremos.

O Pierrô de Schoenberg é uma espécie pêndulo que oscila entre os polos expressivo e construtivo. Por um lado, vemos o expressionismo musical elaborado sob os poemas Madonna, As Cruzes e Decapitação; por outro vemos o construtivismo formal em Noite, Parodia e Borrão de Lua. Neste último o recurso construtivo utilizado por Schoenberg é um prenúncio de nossa situação musical atual e uma memória dos tempos da música medieval: trata-se de uma sobreposição de quatro procedimentos musicais distintos, próximo da maneira como a tradição do moteto medieval bricolava cânones e melodias de diversas canções num mesmo construto polifônico. No Borrão a primeira camada é formada por uma fuga a três vozes elaborada de maneira bem estrita no piano. A segunda é um cânone em caranguejo (termina como começa) na viola e no 
violino. A terceira camada é um cânone simples entre a flauta e o clarinete. E a quarta camada é a voz no meio de toda esta textura complexa. Esta sobreposição de formas, cada uma com suas consequências temporais e construtivas nos parece um prenúncio da multiplicidade de recursos e materiais que a música moderna teria de lidar dali em diante e que diz muito sobre a arte em nosso tempo. É representativo diante de tal formalismo que na sequência de sua fase expressionista o compositor tenha desenvolvido uma fase construtivista por meio da técnica dodecafônica.

Se, no âmbito da reflexão puramente musical, é possível constatar uma oscilação entre extremos, no âmbito geral da obra, os extremos não deixam de se manifestar de maneira intensa. Permitamo-nos, por um momento, uma interpretação poética do texto e da expressão da obra. O bêbado de lua que abre o primeiro ciclo de sete poemas nos verte olho adentro de um inebriante espaço de horizonte mudo. A sedução da Colombina e as flores-luz-da-lua erotizam assim a paixão de um Pierrô pleno em alvura luminosa. Mas pálido, o Pierrô apaixonado flutua com sua cara de cera como um flâneur decadente, um dândi vestido de oriental que aprecia os ramos do branco tecido que a lua verte, como água lívida que a lavadeira banha sonolentamente. Depois destas quatro figuras de suspensão e placidez a Valse de Chopin vem então borrar a tela com o sangue a gotejar nos lábios de um doente. A expressividade melancólica que se espraia luminosa, Mãe do desespero, desenha os cadáveres verdes enquanto o mundo se diverte. A lua está doente, moritura lua, que dos céus desaparece.

O segundo ciclo então nos mergulha numa profusão de ardilosas profanações. A noite cinza repleta de negras borboletas pede ao Pierrô que recupere o riso, lua que passou - passou. E ele elabora seu roubo, sob o olhar de mil olhos que miram o sono dos mortos. O sangue continua a gotejar e agora vem da hóstia - vê-se a forca - e o terror faz o Pierrô tropeçar. Quando deitado ele jaz em seu divã mental, sente em seu pescoço o frio da lua, um sabre oriental que vem para decapitá-lo. As cruzes benzem o palhaço morto e ficam as feridas por onde sangram os poetas; "cruzes santas são os versos".

O terceiro ciclo de sete poemas se abre com a nostalgia, a memória de seus idos da Itália e suas velhas pantomimas, que trazem de volta o nosso bufo herói vencido. Grotescamente pierrô fuma um fumo turco na cabeça de Cassandro em busca de paraísos artificiais para apagar a memória de suas atrocidades. Sonha com Bérgamo, sua terra natal; para lá aponta a barca de seu regresso cuja o leme é a lua. Mil grotescas 
dissonâncias faz pierrô numa viola, espalhando o borrão de lua por toda atmosfera. $\mathrm{O}$ velho olor lhe traz ideias doidas a dançar:

\footnotetext{
“toda a tristeza se desfaz

Pela janela iluminada

Eu vejo a vida que me vê

Sonhar além a imensidade....

Ó velho olor - dos dias vãos!"
}

O caminho do Pierrô então oscila como lua entre a placidez e a violência, o riso e o desespero, o trágico e o cômico. O palhaço mergulhado na escuridão do imenso universo apresenta assim uma subjetividade solitária que se reabsorve a si mesma ("eu vejo a vida que me vê"), na embriaguez e na desolação. Depois do erotismo e da violência, a terceira parte do Pierrô esboça uma reconciliação, espaço onde é possível sonhar além da imensidade, mesmo sabendo dos dias vãos. É a imagem de um náufrago das estrelas, que em devaneio apresenta-nos uma esperança desesperada. Cem anos depois do Pierrô e mesmo com brilho ocultado pela fumaça, a lua ainda produz em nós a melancolia e a euforia, o mesmo desespero esperançoso. Nossa sociedade ainda não encontrou sua reconciliação. A crítica ao naturalismo ainda não se realizou. Seguimos oscilando como as marés entre a capitulação de uma tragédia e o riso que oferece alguma utopia para a humanidade. A expressão de Schoenberg ainda vive pois ainda não se realizou.

Para além desta interpretação poético literária do Pierrô Lunar e para além do aspecto de liberação da convenção no interior do opus 11 , faltaria para completar esta reflexão a respeito do expressionismo em Schoenberg uma reflexão sobre a ruptura com o aspecto temporal da obra tradicional. Pois se Schoenberg, como vimos no primeiro movimento do opus 11, mantinha em operação um esquema formal ABA que garantia a unidade da forma temporal, no último movimento, bem mais curto em termos de duração, o aspecto de recapitulação desaparece. O tempo passa como se fosse uma flecha unidirecional sem memória, pura expectativa que se dissolve. O modelo miniaturista, que nas palavras de Schoenberg no prefácio às bagatelas de Webern, era capaz de portar toda uma epopéia em um gesto musical, opera assim uma crítica ao modelo extensivo do romantismo. Isso fica evidente no opus 19 de Schoenberg. Mas o que num primeiro momento foi tomado como radicalidade estética e novidade logo se 
configurou como um problema. Sem o esquema geral que a harmonia tonal operava ao elaborar as formas dinâmico expressivas tornou-se quase impossível construir grandes formas com unidade. Tudo se distanciava da forma orgânica e se aproxima da schubertiana forma cristalina. É neste sentido que a oscilação entre os extremos do tematismo e do atematismo, do subjetivo ao objetivo levou Schoenberg a descobrir o método de composição com doze sons.

O dodecafonismo se insere no interior da história da música como avanço das forças de dominação do material. Nas palavras de Adorno nada mais é que uma ampliação da paleta do compositor. A série torna-se material do qual disparam todas as relações da obra, tornando se um todo articulado e fechado em si mesmo onde cada nota diz respeito ao seu universal serial. Trata-se objetivamente de uma recuperação da forma orgânica tradicional agora liberta do sistema tonal. É simbólico que a fase dodecafônica de Schoenberg tenha vindo acompanhada da elaboração das formas tradicionais da música instrumental, como por exemplo, as formas de dança. A prevalência do contraponto acima das relações harmônicas imediatas remete àquele desenvolvimento de autonomia dos renascentistas. O próprio procedimento técnico como disparador da obra é o ápice da autonomia musical. Dialeticamente dominação do material total converte-se em anulação do polo subjetivo da música, a música tornara-se mais uma vez expressão de seu próprio procedimento técnico sendo o sujeito mero articulador formal.

"a técnica se converte em fim em si mesma e subtitui a unidade substancial da obra de arte pela mera unidade do "próprio acontecer". (...) Apesar de toda a retidão do procedimento técnico a respeito do material não se pode desconhecer de todo um longiquo parentesco com aqueles aparatos cênicos que empregavam incansavelmente toda sorte de máquinas e têm inclusive a tendência de assimilar-se à própria máquina, sem que esta cumpra uma função: a função permanece somente como alegoria da "época técnica"” (ADORNO, FNM, pág 61)

A subjugação do sujeito ante a técnica é resultado da total dominação da natureza que o mundo administrado é espelho. Neste sentido não deixa de ser surpreendente a habilidade dialética de Adorno ao apontar que uma das principais, senão a mais relevante constatação crítica da Filosofia da Nova Música era que: "os extremos opostos da composição musical, Schoenberg e Stravinsky, se tocam ao fim" 
(ADORNO, 1966, p. 11) Pois ambos, Schoenberg e Stravinsky, manifestam nas suas obras a coerção social como debilidade da subjetividade. Se por um lado, no dodecafonismo, Schoenberg busca na necessidade e ordem a solução para a inconsistência formal dos novos materiais, o que leva a uma anulação crítica da expressão, por outro lado, Stravinsky com o neoclassicismo impõe ideais de autenticidade já desgastados na história, o que leva a uma violenta falsificação da expressão sob tal exigência.

"Nos dois, é claro que em planos de configuração completamente diferentes e com diversa capacidade de realização, a objetividade se formula subjetivamente. Nos dois a música ameaça tornar-se rígida no espaço. Nos dois todo elemento musical individual está predeterminado pelo todo e já não existe uma autêntica interação entre o todo e parte. O imperioso domínio sobre o todo elimina a espontaneidade dos momentos particulares" (ADORNO, 1966.p. 62)

Esta constatação trata antes de tudo da tendência da música moderna à rigidez no espaço, a espacialização estática da música. Pela contração do princípio expressivo, fruto da reificação do material tomado como facticidade exterior autêntica, no caso de Stravinsky, ou fruto da total dominação do material no caso da dodecafonia de Schoenberg, a tendência à estaticidade se apresenta nos dois extremos como limitação da experiência temporal. Frente ao nada se ganha e muito se perde do uso estrito da técnica dodecafônico, o próprio Schoenberg superará sua configuração mais rígida:

"Não há dúvida de que a codificação e racionalização que se chamou de dodecafonismo sacrificou muitos dos princípios formais que já haviam se manifestado na música mesma. A forma definitiva, sistemática, que essa técnica alcançou a custa da flexibilidade dos elementos da técnica compositiva da qual era herdeira; a coerência sem fissuras da composição dodecafônica estava acompanhada de uma reificação que não havia ameaçado suas pré-formações.” (ADORNO, OC 16, Escritos Musicales I-III, p. 84)

A última fase de Schoenberg, a do estilo tardio, é marcada então por mais um movimento de superação dialética do compositor. Schoenberg permite que no interior do rigor construtivo da técnica dodecafônica ressurjam materiais eminentemente tonais como tríades, mas agora já desprovidos de sua função original. O esforço de Schoenberg consistia em recuperar a temporalidade musical: "as últimas composições de Schoenberg são dinâmicas e a técnica dodecafônica contradiz a dinâmica.” 
(ADORNO, FNM, P.82) O caminho de extremos de Schoenberg servirá de modelo aos compositores da década de 50 e 60.

Serialismo Integral. O diagnóstico de Adorno no ensaio $O$ envelhecimento da nova música (1955) se funda exatamente nesta constatação de uma tendência à estabilização da expressividade musical. Pode parecer paradoxal falar em envelhecimento do novo, mas Adorno tem em vista duas questões que dizem respeito direto a sua concepção de arte: para o filósofo a música tem como sua essência a recusa de aceitar as coisas como estão dadas, o status quo; e a música tem sua justificativa e legitimidade ao dar forma e voz àquilo que as superfícies convencionais da vida cotidiana tendem a esconder. Neste sentido o filósofo atesta conformismo dos compositores do pós-guerra para com o atual estado da produção musical, o que lhe surge como falsa satisfação. Para Adorno o conceito de Nova Música só veio à tona quando a música se colocou sobre uma dúvida hiperbólica, e não quando ela estava certa de seus caminhos. A música da década de 50 parece assim não atingir mais o choque motivado pelo impulso crítico das principais obras modernas da Nova Música como a Sagração de Stravinsky, Canções de Altenberg de Alban Berg: "O envelhecimento da Nova Música significa nada mais que este impulso crítico esta em declínio" (ADORNO, 2002, p. 181)

$\mathrm{O}$ cerne da crítica de Adorno diz respeito à atitude dos compositores da época para com o material e a história. Como enfrentamento à história, como crítica da tradição, as vanguardas da década de 50, trataram de buscar eliminar todo e qualquer vestígio do passado em suas obras. Através da técnica, seu esforço principal era a renovação do material musical, a ampliação, domínio e racionalização cada vez maior dos meios de produção musicais para que o Novo surgisse como força crítica à tradição: para Adorno este impulso torna-se tecnocrático, pois aceita-se este recurso a técnica sem realmente problematizar-se o que isso serve à música; "avanços no material dificilmente contribuíram para garantir qualidade a qualidade das obras que o usam" (ADORNO, Essays on Music, pág 182). O filósofo lembra para sublinhar o perigo do fetichismo do material tecnológico o dito de Schoenberg a respeito do método dodecafônico: pouco se ganha com este método e muito se perde. Para Adorno mesmo com todo o avanço técnico dos primeiros 10 anos do pós-guerra, a qualidade da música em geral decaiu e se perdeu. 
Adorno tem em vista a produção geral que se apresenta nos "Festivais de Música", e que o filosofo, não sem ironia, chama de "Música de Festival de Música". Sempre atacando ostensivamente os intentos restaurativos dos neoclássicos Adorno, no entanto, tem em vista justamente a produção que se arroga mais avançada. Para ilustrar o deicaimento da qualidade Adorno afirma: "A sonoridade continua a mesma. Mas a angústia que deu forma para a base das grandes obras foi reprimida" (ADORNO, 2002, p. 182). Adorno apresenta uma anedota para tentar exemplificar o que se passa no decaimento do impulso crítico, dando um exemplo de Kierkegaard: se antes o abismo amedrontava e representava a morte, agora passando sobre o trilho de trem que o corta, pode-se observar as profundidades confortavelmente. O filósofo busca assim apontar como antes, aquilo que para ele era justificação e essência da arte - seu inconformismo - agora passa a ser tratado com desdém sem resistência.

O decaimento do impulso crítico também é apontado em certos expoentes dos anos heróicos do movimento vanguardista do início do século. O principal exemplo no caso é Bela Bartok. Adorno mostra como mesmo este que é um dos maiores compositores do século, no fim da sua vida, se dobrou à música tradicional abandonando a enervação crítica que suas obras mais radicais portavam. Se a música tradicional em Bartok a princípio era recuperada como retorno ao primitivo que contém ainda algo que resiste e opera uma crítica às convenções tonais vigentes, no seu Segundo Concerto para Piano o tom já é totalmente conciliador e a técnica não ultrapassa as variações temáticas brahmisianas. Adorno vê nesse movimento duas causas: uma é marcada certamente por certa ingenuidade do especialista musical, que resolve atender seu meio musical como quem responde a uma demanda do mercado, abandonando o espírito objetivo; a outra é marcada pela cisão radical entre a Nova Música e o público em geral, que fez com que os compositores se dispersassem em diversas frentes indistintamente, atestando o aprofundamento da crise da vida musical.

O polo produtivo que Adorno tem em vista para elaborar sua crítica apresenta-se na transformação operada pelas vanguardas de Darmstadt do método dodecafônico em sistema e a crença na faticidade dos novos materiais desenvolvidos nos últimos anos pelas vanguardas. Para tal o filósofo desenvolve uma espécie reconte de genealogia da técnica dodecafônica ${ }^{26}$ mostrando como esta é fruto do desenvolvimento da musical tonal, da construção temático-orgânica de Brahms, expandida pelo cromatismo

\footnotetext{
${ }^{26} \mathrm{Cf}$. ADORNO, A pré-história da técnica dodecafônica. OC. 16.
} 
wagneriano. Como vimos, diante de materiais novos nas obras da juventude Schoenberg, a articulação expressiva e linguística da música, isto é, suas transições, exposições, campos de tensão e relaxamento não abandonavam totalmente sua relação com a tradição histórica da música da qual eram herdeiros:

“os materiais disponíveis, hoje no presente, todos brotaram do solo da tonalidade. Quando transformados em material não-tonal, resultou disso uma certa inconsistência, uma espécie de fissura entre o sujeito-temático musical e a forma musical" (ADORNO, 2002, p.. 186)

Esta tensão marcada pela incapacidade do sujeito musical em articular expressivamente as formas do novo material passou a exigir um fortalecimento dos princípios construtivos das obras. Neste sentido, é paradigmática a obra de Anton Webern, discípulo mais radical de Schoenberg. Até o desenvolvimento do dodecafonismo as obras de Webern eram praticamente todas aforismáticas, de pequena duração: a expressão via-se limitada ao suspiro e calafrio de alguns segundos e a forma era garantida principalmente pelo uso do cromatismo orgânico. Do dodecafonismo em diante Webern passa a tentar articular formas cada vez mais estendidas fazendo uso do serialismo de maneira expandida, o que serviria de modelo a ser aprofundado pelas vanguardas de Darmstadt.

Adorno tem em vista principalmente Pierre Boulez, aluno de Leibowitz que introduziu o dodecafonismo na frança, e de Messian responsável pela serialização de durações, que em 1952 compõe Estrutras I, peça para dois pianos composta com o uso do serialismo integral. Alturas, intensidades, durações, ataques, todos os parâmetros musicais pré-ordenados por disposições seriais e integrados por estruturas prédeterminadas gerando uma racionalização total do material musical jamais vista. Estruturas torna-se símbolo de música gerada por automatismo na qual o compositor pré ordena o material e ao articulá-lo mecanicamente a obra é gerada. Boulez tinha em vista a eliminação de qualquer "liberdade composicional", pois na expressão livre o compositor inconscientemente carrega consigo a tradição histórica da linguagem musical em que foi formado, e de fato como afirma Adorno, todo impulso subjetivo é em música ao mesmo tempo um impulso de linguagem musical.

A rejeição da expressão, tomada como portadora da transfiguração ideológica que a sintaxe romântica portava no século XX como linguagem reificada e desgastada, era levada ao extremo em prol da construção técnica total das obras. De fato a crítica da 
expressão foi fundamental para anular os gestos vazios e ornamentos que foram fetichizados pela sociedade de massas moderna, mas com a crítica da expressão a categoria de sentido musical foi colocada em cheque:

\footnotetext{
"mesmo o sem-sentido pode apresentar sentido, como um contraste à e negação deste, assim como em música a ausência de expressão é uma forma de expressão" (ADORNO , 2002, p.. 192)
}

As novas vanguardas tomavam para si tal programa de ausência de sentido lingüístico e no lugar do impulso subjetivo colocavam a organização total e esquemática como puro ser fático a ser ouvido na composição. "A palheta torna-se a pintura". Diante desta crítica total da linguagem musical operada por Boulez, Adorno apresenta sua principal crítica da produção da década de 50, a espacialização da forma musical como forma estática:

“a Base deste serialismo é uma ideia estática de música: as correspondências precisas que a racionalização total requer são fundadas na pressuposição de que o elemento idêntico que recorre na música é de qualquer forma atualmente equivalente, como se fosse uma representação esquemática do espaço.” (ADORNO, 2002, p. 188).

Pois na música, no decorrer de sua temporalidade, aquilo que é idêntico pode surgir em outro momento de reprise como não-idêntico. Um dos efeitos mais arrebatadores da linguagem musical consiste na recorrência deslocada de materiais idênticos, o que elabora uma temporalidade fundada na duração. A construção pontilista gerada pela música serialista anula qualquer capacidade de memória da escuta, de escuta relacional, o que retira o equilíbrio temporal de uma obra tornando-a uma espécie de massa cinzenta, de pausa-evento-pausa-evento, sem contraste. Se a expressão estava extirpada do processo composicional ela também é fragilizada na recepção da obra.

“Os esforços para atingir a racionalização total da música, de qualquer maneira, são eles mesmos dependentes das fronteiras da escuta - que é a fronteira da racionalização da música.” (ADORNO , 2002 , p. 188)

Pela extrema racionalidade de seu procedimento a música moderna advinha irracional. A defesa da elaboração de uma forma que seja capaz de expressar um sentido composto a partir de uma ideia artística e que permita a reconstituição uma temporalidade musical marcada pela duração é um dos pilares do projeto adorniano de 
racionalidade musical, mas que só será devidamente desenvolvido nos textos futuros de Adorno. Aqui o texto Envelhecimento da Nova Música termina de maneira elíptica:

"A atual paralisia das forças de produção musical representa a paralisia de qualquer livre iniciativa neste mundo da total-administração, o qual não tolera nada que exista fora dele ou que não seja integrado como elemento de mera oposição (...) As únicas obras autenticas produzidas hoje em dia são aquelas que conseguem medir na sua organização interna a completa experiência do horror (...) e a possibilidade de se recuperar a força artística (...) está preservada exclusivamente na solidão desesperançada "(ADORNO, 2002 p. 20)

Forma - É frente a este diagnóstico que na década seguinte Adorno elaborará ao lado de Dahlhaus e Ligeti sua crítica da forma no interior da música nova. Tomemos este poema expressionista dos primeiros anos do século XX citado pelo prof. Jorge de Almeida, no seu livro Crítica Dialética nos anos 20, que aponta uma contradição latente: a revolta proclamada pelo conteúdo do poema encontra-se limitada pela regularidade da forma métrica. "a figura paterna da tradição vinga-se no reconhecimento de que a nova geração, apesar de toda a revolta, não conseguiu desatar os vínculos que a prendiam ao passado" (ALMEIDA, 2007, p. 68)

“Forma e Volúpia" - Ernst Stadler - Trad. João Barrento.

Foi preciso que forma e ferrolho rebentassem,

E que mundos por tubos abertos penetrassem:

Forma é volúpia, paz, divina contenção

Mas eu quero resolver tudo, torrão a torrão.

A forma quer atar-me e limitar-me,

Mas com todo o meu Ser em tudo hei de espraiar-me.

A forma é rigorosa, clara, sem piedade,

Mas para os fracos e pobres vai a minha amizade,

E nesta oferta de mim mesmo, sem limitação,

A vida me dará plena compensação.

Como vimos, foi contra esta contradição da música herdada da Escola de Viena que os vanguardistas do pós-guerra decretaram a morte da estética de seus antecedentes. É simbólico o dito de Boulez que declarava a quatro ventos, com o espírito polemista usual, a morte de Schoenberg e a ampliação da capacidade crítica do serialismo integral em expurgar a linguagem musical de todos os seus vestígios da tradição. Neste sentido a 
crítica da forma não simplesmente se aprofundou como, de certa maneira, foi tomada praticamente como auto evidente, ou seja, expurgada a linguagem de toda a sua tradição pela serialização de todos os parâmetros musicais, independente da forma que se manifestasse, sua validade crítica estava garantida pela pureza do material.

Em textos publicados entre 1965 e 1966 Adorno, Dahlhaus e Ligeti trataram especificamente do problema da forma na nova música para dar conta do vazio de reflexão a que a categoria de forma havia sido relegada. Aproximaremos-nos destes textos para apontar os impasses da forma na música nova, o que se apresenta como articulação central na compreensão das relações entre construção e expressão no interior da obra de arte.

O termo forma no grego advém de morfé, mas é na sua versão latina que sua acepção se torna clara: forma é figura exterior, aparência, feito em molde. A acepção mais comum é aquela que relaciona parte e todo, dando ao objeto o seu feitio. No âmbito da física pode-se falar em forma líquida ou gasosa, o que por si só já relaciona diretamente forma e conteúdo. Pode-se pensar também no comportamento do homem, sua forma de agir e viver, sua forma de vida. O processo educacional também é considerado um processo de formação enquanto delineamento da subjetividade de um homem. Poderíamos lembrar aqui da acepção que forma ganha na botânica fazendo referência à Metamorfose das Plantas de Goethe que, como vimos, toma a forma primordial a categoria mais baixa no interior de sua taxionomia. Com Platão vimos que a forma se aproximava da ideia, essência imaterial dos objetos, o arquétipo. Já com Aristóteles a forma ganha sua acepção mais comum como determinação, delineamento e modelação da matéria bruta, fazendo com que o ser adquira identidade imagética. Poderíamos falar em forma ainda segundo as reflexões kantianas, como aquilo que organiza o campo da experiência em categorias, leis e estruturas que nos auxiliam na clarificação do caos da multiplicidade do sensível. Muitas outras acepções seriam memoráveis e talvez a mais atual delas seja aquela que coloca no centro da vida humana pelo capitalismo: a ideia de forma mercadoria. Uma forma abstrata e equivalente, que se ancora num encantamento da aparência ocultando os processos de extração da matéria e trabalho histórico que se metamorfoseiam na forma do valor de troca. A forma mercadoria, com sua mutabilidade e capacidade de adaptabilidade é hoje a forma dominante em nossa sociedade. Destes rápidos apontamentos torna-se evidente que o conceito de forma se mostra deveras amplo e para se tornar útil ao pensamento crítico musical deve passar por uma particularização de seus componentes gerais. 
No âmbito da estética musical conforme afirma Dahlhaus em seu texto sobre a Forma (Dahlhaus, 1989, p. 248) a urgência em definir, detalhar, surge tão fortemente quanto a necessidade de dissolver e romper com os conceitos e categorias. Como vimos, é possível falar de muitas coisas diferentes sobre o signo da palavra forma. No entanto Dahlhaus defende que a expressão forma é tão respeitável como é ambígua, e deve nos servir principalmente como palavra chave. Se no âmbito da literatura no século passado a palavra formalismo ganhou potencial crítico, no âmbito da música era vista com suspeita de quem se apegava as formas tradicionais do passado, submetendo sua criação a padrões esquemáticos. No entanto, bastaria lembrar de alguns termos cunhados por Stockhausen como forma pontilista, forma momento, forma estatística para ver que o debate sobre a forma estava longe de ser um debate superado.

Dahlhaus então procede como de costume em seus textos uma crítica da crítica levantando facetas do conceito para melhor compreendê-lo. Lembrando de Aristóteles Dahlhaus afirma que a forma é sempre uma categoria relativa. Em contrates com as notas individuais, o motivo representa uma forma assim como a ideia de período esta em relação com os motivos e a ideia de movimento em relação aos períodos. A concisão formal é diferente em cada nível de observação. Definir um período como antecedente de um consequente não é menos complexo. Se tal abstração e indefinição do conceito de forma já é complexa na música do passado, na música atual esta dificuldade só se incrementou.

Adorno no seu texto Forma na Nova Música desenvolverá esta questão ao refletir sobre a função da cadência, apontando como a forma é diferente do formado, e conteúdo e forma se mediatizam no interior das obras. A Forma na música tradicional funciona como um jogo de peças com o qual se monta. Tratou-se de uma relação de sedimentação histórica que consolidou a equiparação entre forma e esquema, como por exemplo, o rondó, que remete às estruturas da dança com Couplet e Refrão. Entender o Rondó como forma significa reconhecer estes segmentos. No entanto a demarcação destas partes gerais depende de conteúdos particulares específicos. No caso da música tonal a cadência sempre cumpriu este papel. A cadência é o ponto de unidade entre forma e conteúdo. Contra esta função estereotipada é que os compositores foram rasgando o tecido e romperam com a "conclusividade" da cadência o que, como vimos, desde Beethoven levou à desintegração do idioma. Com a desintegração das convenções de conteúdo que garantiram o delineamento da forma foi colocado em cheque a própria 
possibilidade da forma na música nova. Mas antes de apresentar mais claramente este diagnóstico voltemos à definição de forma musical.

No seu texto "Forma na Música Nova" (LIGETI, 2001, p. 139) Ligeti parte da definição usual de forma: forma como relação entre as partes e o todo, fazendo referência à ideia de organicidade, ou seja, a ideia de organum, como organização, órgão que participa de uma sistematicidade e de um corpo maior. No entanto se nos aprofundarmos nesta acepção veremos que a forma musical se aproxima daquilo que Dahlhaus e Adorno tinham em vista: a forma como organização dos aspectos sintáticos da obra. "a noção de forma musical não se aplica apenas a aspectos da relação entre as partes, mas também a maneira de agir das partes ao seio do todo" (LIGETI, 2001,p. 140)

A relação entre frases e períodos, lugar e função no todo, ligação ou independência, proximidade ou contraste, o que gera a aparência de movimento ou estabilidade, são entendidos como a função das partes e isso é o que aparece aqui como mais decisivo do que a mera enumeração dos componentes de uma forma. Em contraposição a esta concepção qualitativa de forma, a versão descritiva ainda é importante. Pensando nela Ligeti nos lembra da relação que o próprio conceito de forma estabelece com a espacialidade, com a imagem. A forma é uma abstração de configurações espaciais entre a relação dos volumes de objetos. Transpondo isso ao domínio musical, que é essencialmente temporal, a forma surge como abstração da abstração. Diferentes intensidades podem gerar a aparência de distância. Pode-se falar em espaço harmônico, fragmentos, figuras e partes que são conceitos musicais, mas que fazerem referência direta a espacialidade. O próprio desenvolvimento musical aparece como arquitetura temporal sobre o espaço. Quando percorremos o antecedente e o consequente tudo se apresenta como totalidade formada. Assim Ligeti pretende fazer uma diferenciação central entre a música no âmbito puramente temporal e sua abstração enquanto constituição de uma forma musical, que é responsável pela visão espaço temporal num campo virtual da percepção. "A forma musical existe diante daquilo que se transforma, em vista de um conjunto retrospectivo, o desenvolvimento temporal da musica em "espaço". A via do conjunto retrospectivo é a história" (LIGETI, 2001, p. 140).

A via histórica surge dentro da obra, mas sempre na relação entre as obras. Sua função só aparece diante da comparação com a tradição, os estilos e os gêneros. $O$ fator histórico influencia tanto na sintaxe como na relação espacial: 
“O tempo real no qual a música se desenrola - um tempo que aparece na forma musical como espaço imaginário - não é somente o nível temporal da obra: a qualquer instante, um tempo imaginário entra em cena, um tempo com um pulso superior de qualquer tipo, engendrado pela compressão do passado que precede o desenvolvimento temporal real da obra particular. Este tempo imaginário é a seu turno transformado em espaço por um fenômeno de abstração: a história, tempo e memória relacionado ao presente é assim de natureza espacial imaginária.” (LIGETI, 2001, p. 141)

Ligeti então nos oferece alguns exemplos da tradição para pensarmos sua concepção de forma: a sonata clássica vienense e suas transformações históricas é paradigmática nesta reflexão. Composta através da articulação de temas com pontes modulantes, desenvolvimento, transição para a reexposição e coda, estes elementos são reconhecíveis principalmente pela sua posição na grande forma. Isso sempre unido a características harmônicas, rítmicas, motívicas e aos tipos de modulação. Estabeleceram-se desta maneira em torno daquilo que se pode chamar de convenção histórica, material sedimentado. Já no romantismo, contra a convenção, a forma se mantém, mas seu conteúdo faz com que seu sentido mude radicalmente. Ligeti nos oferece como exemplo o uso do material característico do finale de uma sinfonia logo na abertura $7^{\text {a }}$ Sinfonia de Bruckner, a forma musical se inverte, ela começa como deveria acabar. Tal exemplo exige uma recompreensão da mediação entre material e forma, e num âmbito superior, entre conteúdo e forma. A alteração da posição do conteúdo traz diversas consequências para a compreensão do sentido formal, de sua significação. "É justamente a consideração da completa significação formal da tradição que revela a totalidade do sentido e que tende a ligar uma configuração musical presente às configurações aparentadas que em si ressoam a historicidade de uma maneira subjacente." (LIGETI, 2001, p. 143)

Para compreender o que a noção de Significação diz respeito à forma musical Ligeti faz recurso a uma série de ideias de Adorno, principalmente apresentadas nos textos do filósofo sobre A relação entre Musica e Linguagem e sua monografia sobre Mahler. Trata-se de compreender a sintaxe musical na sua relação entre as partes a partir de uma semelhança com a linguagem falada. Como vimos, só aparentemente são semelhantes, pois a linguagem musical é toda arruinada, despedaçada e muda. Diz tudo ao mesmo tempo em que o vela, brilha tanto em sua pureza que cega. Daí o problema da forma ser tão decisivo na linguagem musical. Pois sua relação com a lógica e 
construção habitual da linguagem é sempre duvidosa, mesmo sua aproximação com a matemática é problemática. A música certamente comporta sistemas lógicos, no entanto estes só ganham valor estético ao se apresentarem como aparentemente compreensíveis. “A significação musical e a lógica musical se comportam em relação à significação e à lógica efetiva como os sonhos se aproximam da realidade.” (LIGETI, 2001, p. 143) Assim a função de um trecho musical só é compreensível diante de um contexto histórico, não nas obras particulares. Para Ligeti o sistema da forma musical e de suas transformações na história pode ser comparado como uma imensa rede que se desenvolve ao longo do tempo: cada compositor contínua a trançar esta rede, criando novos nós e encontros, que são contínuos ou desviados de uma maneira a cada vez singular. Mesmo a ruptura, o rasgar da rede, faz com que este só seja perceptível frente à negação de todo o resto. "mesmo aquilo que aparenta não ter relação e tradição possuí uma ligação secreta com a história" (LIGETI, 2001, p. 144)

Como vimos no início deste texto, as vanguardas do século XX buscavam se libertar das formas herdadas da história. Boulez falava em tabula rasa da tradição. Ligeti em seu texto fala da tendência para a composição "a-histórica" que tinha em John Cage e seu descompromisso stravinskiano o seu principal representante. A crítica e negação da ideia de forma era assim central para os expoentes da vanguarda pós-45.

Ligeti aponta quatro diagnósticos centrais na crítica da forma tradicional pelas vanguardas do pós-45. O primeiro é aquilo que já era conhecido desde a segunda escola de Viena, mas que só se torna dogma anos depois: já não existem mais esquemas formais pré-estabelecidos. Cada obra particular apresenta sua própria forma fruto da autonomização de seus procedimentos com relação a esquemas externos. O segundo diagnóstico apontado por Ligeti é a liberação da articulação rítmica de toda base métrica ou pulsada; liberação esta que atinge diretamente uma das principais bases da articulação formal da música do passado. Este movimento de liberação, como aponta Ligeti, leva a uma tendência geral de indiferenciação geral dos parâmetros de organização da forma. O terceiro é a negação te toda e qualquer sintaxe musical materializado no dito objetivista de John Cage de que os sons são apenas sons, não importando muito a relação linguística estabelecida entre eles. E o último elemento que faz par com a anulação da sintaxe é a mudança da função formal. As partes das obras atuais já não tem necessidade de ordenamento diante do todo. Diversas maneiras de se distribuir o sonoro, ordenar os objetos sonoros, os campos, as figuras, já não operam mais no campo de função fixa no interior da forma. Destes quatro diagnósticos Ligeti 
tira a seguinte conclusão fundamental a respeito da forma musical de seu tempo: "o caráter vetorial da função formal se perdeu" (LIGETI, 2001, p. 146) É a tendência ao estatismo diagnosticada por Adorno já em 1954 no seu ensaio sobre o envelhecimento da nova música, que Ligeti agora reconhece como um diagnóstico premonitório.

Ligeti nos mostra como certos comportamentos do material musical de sua época já se aproximavam das antigas funções: clusters, acelerando e ritardandos, gestos bruscos e saltos intervalares radicais, assumiam depois de passados alguns anos aquela característica linguística da convecção tão combatida pelos compositores. Para fugir deste caminho os compositores passaram a se focar menos na elaboração de uma obra apresentada como produto e mais em uma obra que se apresentasse como processo. Depois de 1945 os compositores trataram de eliminar o sujeito, tendo como o sujeito expressivo o portador da tradição. Dai o prestíssimo de mudança e obsolescência das técnicas, nenhuma convenção era aceita. Dahlhaus faz um belo e severo diagnóstico deste problema.

Basta pensar nos termos usados por Stockahausen para falar de suas formas: forma pontilista, forma de grupos, ou forma estatística. Todos eles se referem primariamente a elementos do processo criativo e não da manifestação em-si da música. A ênfase na performance e no processo se fazia sentir por toda parte, enquanto só aumentava a incerteza no campo composicional. Dahlhaus então aponta que a geração pós-45 fazia uma profunda confusão entre o que era realmente a forma na música e seus aspectos técnicos e construtivos. Dahlhaus vai aprofundar tal leitura apresentando a diferença entre estrutura e forma.

Segundo Dahlhaus o conceito de estrutura ocupa o meio termo entre o conceito de forma e de técnica composicional. No entanto para o crítico, o termo estrutura adquiriu uma hiperfunção que visa ideologicamente substituir o conceito de forma. Para desmistificar seu uso Dahlhaus precisa as diferenças entre ambos: o termo estrutura sugere detalhe e conexões em um pequeno espaço, enquanto que forma sugere uma totalidade relativa, que opera relações de larga escala; estrutura pode se referir a componentes abstratos de uma obra musical, como por exemplo, sua estrutura de alturas, o que a separa da esfera de manifestação sonora onde todos os parâmetros se entrepassam apresentando uma forma geral; estrutura tende a ser um conceito técnico que diz respeito a gênese de um trabalho, ao processo de produção, enquanto que a forma é uma categoria estética que se refere ao produto, a sua manifestação audível. Uma estrutura não precisa ser audível; o método não necessita se tornar aparente no 
resultado. A ideia de uma forma musical inaudível seria uma contradição em termos. "Estrutura é o aspecto da obra dirigido ao compositor, forma é o que é dirigido ao ouvinte" (DAHLHAUS, 1989, p. 261). Assim se falamos de forma é preciso atentar para o fato trivial que é sem sentido sacrificar a linha geral de uma obra em prol dos detalhes de sua estrutura, o desenho geral e concreto de uma música em função de componentes abstratos, o resultado substituído pelo método.

Adorno por sua vez reafirma o problema envolvido na crítica das convenções os através da flexibilização do controle do eu no compor. Trata-se do abandono do momento onde o compositor escolhe positivamente o sentido da obra. Querem fugir da figura do compositor enquanto polo expressivo de espontaneidade absoluta. $\mathrm{O}$ dodecafonismo por um lado, organizava os elementos alheios ao eu na composição. Por outro lado temos o acting composing, ou composing action como fuga da elaboração racional da subjetividade. O mesmo se dá naquilo que se convencionou chamar de obra aberta, forma que porta uma variabilidade da ordem das sessões ou da interpretação da notação. Dahlhaus aponta como a forma só aparece aberta ao intérprete, pois no resultado da manifestação da obra a variabilidade é esteticamente fíctícia. "para o ouvinte a forma aberta não existe. O que é forma variável no papel é fixado na performance " (DAHLHAUS, 1989, p.262) .

Deste rápido diagnóstico dos três autores podemos então reconhecer um ponto em comum central: a necessidade de recuperar a auditibilidade da forma. É tendo em vista tal objetivo que Adorno em seu texto fará uma profunda defesa da recuperação da categoria de fantasia formal por parte dos compositores. Frente a instabilidade das técnicas e padrões composicionais adorno afirmará que "A única possibilidade todavia aberta é da auto imersão do ouvido nos momentos idiomáticos, transcendentes cujo deposito é o sujeito" (ADORNO, 2008,p. 635) A categoria então que é responsável pela mediação do sujeito e da realização da forma é aquela cunhada por Schoenberg quando este precisava defender a maneira como escolhia seus encadeamentos harmônicos inovadores: Formgefuhl, sentimento para a forma, sentido formal:

"sentido formal significa: seguir com o ouvido a música por onde quer que esta queira ir por si; tão distante da vontade imposta, da arquitetura imposta, como das necessidades alheias a ela em que na maioria das vezes se atrincheira o obcecado arbítrio subjetivo" (ADORNO, 2008, p. 635)

Para Ligeti tal objetivo nunca se distanciara de suas composições. Em caminho oposto ao hermetismo e a-formidade dos epígonos de Darmstadt, Ligeti jamais 
abandonou a via da auditibilidade da forma. Neste sentido é simbólica sua peça para cravo solo Continuum (1968). A peça já é questionadora ao escolher o cravo como instrumento. $\mathrm{O}$ material, o timbre, a memória histórica do instrumento destoam com o fetiche pelos novos sons almejado pelas vanguardas e materializado na música eletrônica. Vale notar que mesmo ao se distanciar da música moderna e eletrônica por sua instrumentação se aproxima desta por sua mecanicidade: continuum é composta de maneira "isocrônica", ou seja, por toda a pela o mesmo pulso regular é mantido mecanicamente, desafiando a estética pontilista e irregular das vanguardas. A peça tem indicação de prestíssimo e duração inferior a quatro minutos o que apresenta um extremo desafio técnico ao executante. No âmbito das alturas a peça tem como centralidade a repetição de pequenos fragmentos escalares e intervalares que vão se sobrepondo em diferentes graus de extensão: 2 por 2, 2 por 3, 3 por 3, 4 por 3 , e assim por diante. É a composição estatística no âmbito do material, mas aqui o compositor não recusa fazer escolhas de seu desenvolvimento no tempo geral da forma. Próxima do estilo minimalista a peça provoca uma série de variações da percepção do fluxo temporal em vista da dilatação, contração ou sobreposição de seus padrões ritmos o que arranca da textura homofônica muitas vezes uma polifonia latente.

A peça tem início no registro médio do cravo e apresenta didaticamente sua variação de pulso com a sensação de aceleração e desaceleração em vista da sobreposição de pulsos. Na segunda sessão, progressivamente percebe-se que o registro vai se ampliando em direção aos limites extremos da tessitura do instrumento com um crescimento da densidade dos fragmentos repetidos. O longo crescendo desta sessão é símbolo da liberação do aspecto temporal.

A última sessão por sua vez se dirige para o extremo agudo do instrumento, finalizando com o desaparecimento da polifonia e apresentando a unidade entre ritmo e altura no âmbito musical pela repetição acelerada do ré bemol que nos aparece como uma nota em contínuo.

Ligeti no genial documentário de Michel Follin sobre o compositor afirma: "quando nos escutamos a peça, a um certo momento nos esquecemos o momento específico e a guardamos como paisagem, como uma unidade”. Este caráter de unidade e compreensibilidade da forma para além das estruturas e sua capacidade de dar forma aos problemas presentes em seu tempo é uma das mais fortuitas lições que Ligeti deixou para a posteridade. 


\section{3 - Aproximações}

Excurso I - O problema da interpretação musical - A reflexão a respeito do papel do intérprete e da execução sempre foi central na compreensão geral do fenômeno musical. Durante o século XX não foi diferente, mas talvez como em poucas épocas da civilização o papel do intérprete e as questões que envolvem a execução musical tiveram central importância e destaque no debate estético, musicológico, histórico e composicional. Apresentaremos aqui um panorama de alguns problemas que surgiram tanto especificamente na prática musical como na sua relação com a sociedade. Trata-se de apresentar e aproximar a questão do intérprete frente à música nova e a música antiga, tendo mais uma vez as categorias de expressão e técnica como norteadoras de nossa reflexão.

Contra a enorme carga de convecção técnica contida tanto nos procedimentos composicionais quanto na reprodução da música do passado, tanto a música nova de vanguarda do período do pós-guerra quanto a prática da música antiga historicamente orientada visaram recuperar a humanidade expressiva do intérprete no interior da prática musical. Apontar os limites críticos destas práticas é um dos objetivos deste texto.

Primeiramente vale então apontar algumas relações sociológicas ao problema, que servem de pano de fundo para o debate especificamente musical. Vimos com o pensamento do sociólogo Max Weber em seu Fundamentos Racionais e Sociológicos da Música, a história do desenvolvimento musical no ocidente - e em tempos de globalização pode-se falar no mundo como um todo - é fruto de um processo autônomo e progressivo de racionalização do material musical, um desenvolvimento positivo dos 
meios técnicos do fazer musical, representados principalmente no âmbito da compreensão do fenômeno acústico e sua organização artesanal e científica; também no âmbito das técnicas de notação e construção da música; e por fim no âmbito do desenvolvimento dos instrumentos musicais, dos meios técnicos. Vele relembrar que o século XX foi na história da humanidade o que vislumbrou como um todo o mais acelerado desenvolvimento dos meios de produção aliado aos meios técnicos científicos, motivados tanto pelo crescimento da produção industrial quanto pelas guerras em vista do domínio político de colônias e mercados. Como vimos, o fenômeno musical, embora elaborado em sua autonomia conforme o conceito de música absoluta do século XIX, manifesta tal estado social de maneira antinômica, ou seja, mesmo com tal autonomia o avanço nos meios de produção na sociedade não deixou imune a esfera das artes em geral e a transformação das relações no âmbito da reprodução afetou mais especificamente a prática da execução musical.

Vimos também que o primeiro elemento social que apresenta um problema direto para música - e especificamente para o intérprete - é o da invenção da máquina e da reprodutibilidade técnica. A caixa de música, o realejo, a pianola, são exemplos de construções técnicas que põem em cheque o papel do intérprete. É notável o interesse da burguesia em adquirir as máquinas de música para ter em sua casa e executá-las para convidados, fazendo do intérprete - pela primeira vez na história do acontecimento musical - uma peça aparentemente descartável. Também os avanços técnicos da gravação musical com a invenção do disco, da fita e do rádio, tornaram a reprodutibilidade técnica da música não mais uma função exclusiva do intérprete: agora todos podiam ouvir suas canções prediletas repetidamente sob quaisquer circunstâncias. É a perda da aura da obra arte diagnosticada por Benjamin no seu famoso ensaio e elaborada criticamente no ensaio de Adorno sobre o Fetichismo na Música e a consequente regressão da audição.

Por outro lado no âmbito do polo produtivo e composicional o problema do intérprete atingia um ápice. Num texto em que reflete justamente sobre instrumentos musicais mecânicos Schoenberg apresenta o problema do intérprete contando uma anedota sobre Mahler: "Mahler estava no topo de sua carreira como intérprete quando afirmou: 'Eu considero que é meu grande serviço ter forçado os músicos a tocar exatamente o que esta nas notas. "' (SCHOENBERG, 1984, p. 326). A exigência colocada por Mahler é signo do crescimento da dominação técnica sobre o fato musical e da exigência de autonomia que as obras atingiam com a racionalização. A história da 
notação musical é a história do detalhamento, do fechamento do espaço improvisativo e intuitivo do intérprete sobre a escrita. Se no início os neumas eram praticamente apenas pontos de apoio e gestualidade da realização musical, no início do século $\mathrm{XX}$ vemos uma escrita total onde tudo parece pré-determinado: a expressão, o caráter, a articulação, a intensidade, a técnica de ataque das notas, o timbre, a própria corporeidade do intérprete etc. As exigências construtivas, a busca da forma orgânica totalmente integrada e o controle da expressão tornavam as obras de arte impenetráveis a arroubos subjetivos e criativos por parte dos intérpretes. Conforme a exigência de Mahler, o intérprete se aproximava assim daquela mecanicidade vigente no âmbito social. Vale lembrar como nota, que neste mesmo sentido da mecanização, a música eletrônica surgida no começo do século tratou literalmente eliminar o intérprete no âmbito da música de vanguarda.

Mas o problema do intérprete ainda possui um elemento mais central: a já referida crise da própria linguagem musical. No início do século XX a enorme carga de convenções herdada da tradição condenava a composição à repetição estilizada do passado que se apresentava sob a forma da expressão tardo romântica que lidava com a exploração total do sistema tonal. A rebelião modernista se dirigiu diretamente contra esta alta carga de convenções, buscando tanto materiais novos como criticando diretamente os materiais desgastados. Este ato de ruptura que pretendia expurgar da linguagem musical sua face de convenção naturalizada resultou numa espécie de explosão de estilos e técnicas, talvez apenas comparável com o surgimento da polifonia ou os primórdios do sistema tonal no barroco. Tendo em vista as exigências postas pela ideia de obra de arte autônoma, os compositores vanguardistas passaram a elaborar obras que já não faziam jus a nenhum estilo geral, nem se preocupavam a priori com as convenções de escuta: cada obra era uma obra, e cada uma portava sua justificação geral, sem referências exteriores à tradição ou programas. A aversão à tradição, o ahistoricismo das vanguardas, principalmente no pós-guerra só aprofundou a crise. O declínio da ideia de obra musical decorrente desta crise, conforme nos mostrou Karl Dahlhaus, levou nosso século a um enfoque menor no âmbito da composição e um maior apelo à performance, o que muitas vezes, impulsionou o tão comum fetiche da personalidade interpretativa em nosso tempo. Por fim, tal crítica da linguagem comum e partilhada da música gerou tanto um vão entre público e a obra, quanto um abismo entre o próprio intérprete e a obra. 
O vão entre o público e a música nova trouxe por sua vez um elemento novo da história da humanidade: um tempo que não escuta sua própria música nova. Desde a grande ruptura do século XX a sociedade permanece demandando os paradigmas estéticos do romantismo tardio que tanto a vanguarda combateu, e que agora surgem ainda estilizados e desfigurados de seu teor de verdade tornando-se muitas vezes pura mercadoria nos setores mais fetichizados da cultura. Um tempo que não aceita sua música nova, precisa criticamente pensar e reinterpretar sua música antiga.

Feito este diagnóstico geral cabe agora apresentar duas respostas da prática musical moderna a tal estado, principalmente no que diz respeito à segunda metade do século XX: por um lado a música nova de vanguarda, que como de costume, apontando uma crítica contra si mesma se abriu ao aleatório e a improvisação, visando reconstituir um plano de expressão natural ao fluxo temporal, restituindo ao intérprete o acaso e a criação espontânea, aproximando o público do momento musical; e por outro lado o movimento de recuperação da música pré-tonal anterior ao século XVIII. É possivel encontrar nesta produção do passado elementos que restituíam e exigiam do intérprete capacidades criadoras e expressivas. Sobre tais relíquias e ruinas deixadas para traz na história, é possível encontrar muitas vezes uma enorme carga de modernidade, o que em geral exige do público uma escuta muito diferente daquela estandardizada pelas convenções herdadas do sistema tonal.

O problema do intérprete na música nova da segunda metade do século XX foi certamente um momento extremo. O desenvolvimento do serialismo integral por Pierre Boulez, Stockhausen, Goyaverts, Eimert e outros levavam a mecanização social para o interior da composição: como vimos, tudo funcionava como uma engrenagem geral que operava em todos os campos da expressão musical, visando extirpar o pathos da gramática do sistema tonal que ainda colonizava alguns parâmetros da música da segunda escola de Viena. Não é a toa que as experiências mais acabadas do serialismo tenham se realizado no âmbito da música diretamente mecanizada como a música eletrônica.

Uma anedota interessante pode servir de ilustração para a questão que se abre a seguir: quando a realização da peça de Pierre Boulez, Structures Ia, composta através do serialismo integral, sentou-se ao piano o próprio compositor e a pianista Yvonne Loriod. Dado o início da execução a pianista interrompe a música e acusa Boulez: "eu passei horas estudando para tocar exatamente o que esta nestas notas e agora você 
improvisa?” Esta anedota dá o tom da crítica que operará John Cage aos procedimentos de composição integral racionalizada.

O compositor americano torna-se célebre pela inclusão em suas músicas de processos aleatórios: trata-se de partituras que contenham imprecisões, novas formas de notação muitas vezes inspiradas na própria música pré-tonal, mas que agora eram conjugadas com a abertura interpretativa na realização de happenings neo-dadaistas. $\mathrm{O}$ próprio Pierre Boulez faz uma leitura de tal transformação na história da música ocidental no seu importante texto Alea de 1957. (BOULEZ, 1995)

O diagnóstico de Boulez é certeiro. Frente à crise da linguagem da música nova os compositores trataram de transferir a responsabilidade para o intérprete. Adorno então postularia: a fraqueza do sujeito composicional, que é a fraqueza dos sujeitos na sociedade, se manifesta na forma estética. A tentativa de recuperação e valorização do papel do executante pelo setor produtivo não deixa de ser uma resposta a tal situação, expressando "o desejo de criar uma complexidade em movimento, renovada, especificamente característica da música executada, interpretada, por oposição à complexidade fixa e não-renovável da máquina.” (BOULEZ,1995, p. 46)

A passagem da responsabilidade para o intérprete não é tão simples quanto parece. Pois no interior de certo contexto musical a semanticidade da obra não permite qualquer intervenção. Não é a toa que os compositores mais aleatórios acabavam por compor suas peças "improvisativas” para intérpretes específicos que garantiam o caráter da execução, como por exemplo, a relação entre Cage e David Tudor. Trata-se do tão tardo romântico e atual fetichismo do intérprete. Por outro lado, tal enfoque na performance e fragmentação das obras não facilitou a escuta do ouvinte, que via-se agora diante de uma música cujo os elementos da memória e da construção orgânica haviam se submetido a uma espécie de "forma-momento" para usar as palavras de Stockhausen. Em sua forma mais extremada tal tendência desembocou naquilo que hoje se configura como Improvisação Livre, música que prescinde de qualquer ato composicional para se entregar ao mero fazer espontâneo da prática musical, muitas vezes repleto de frivolidades estereotipadas da própria música moderna aliada a formas clichês de arco de intensidade caracteristicamente romântica. No limite a música improvisada exclui também o intérprete, pois nela nada se há para interpretar: é a figuração da performance do jogo desportivo. Como diria Adorno com sua dialética: no limite os extremos se tocam. 
É simbólico que por volta dos mesmos anos seguintes ao pós guerra um forte movimento que hoje já esta consolidado tenha dado seus primeiros passos: a então chamada música historicamente orientada, ou informada, ou simplesmente música antiga. Frente ao aumento da acessibilidade à manuscritos e manuais de interpretação produzidos na própria antiguidade musical; frente ao desenvolvimento da luthieria que passa a reconstruir os instrumentos de época de maneira fidedigna e de qualidade; e principalmente frente a superação do sistema tonal que fez com que se reconhecesse que existe história depois e antes dos meados do século XVIII, rompendo com a naturalização do tonalismo, o século XX viu a música antiga tomar fôlego e conteúdo de verdade no interior da situação musical.

Mas por que a recuperação da música antiga não é mero conservadorismo tradicionalista que visa reconstruir de maneira pura e autêntica um passado com modos de escuta, funções da arte e expressividade que aparentemente em nada dizem respeito ao nosso tempo? As reflexões de Harnoncourt em seu famoso livro O Discurso dos Sons parecem apontar caminhos para responder esta questão crítica.

Para Harnoncourt, o fenômeno da música antiga é sintoma - como já dissemos acima - do apartamento de nosso tempo para com a música nova. Para o autor existem então duas formas de se recuperar a música do passado: uma sendo o mais fiel e autêntico possível ao espírito da época da obra, ou seja, se debruçando sobre manuais e métodos de interpretação, organizando consorts de instrumentos de época, estudando a organização da linguagem musical relativa ao período histórico intentado, no limite recriando a escuta íntima que em geral os timbres e intensidade dos instrumentos antigos exigem; e a segunda maneira seria aquela que pretende por sua vez recriar e readaptar a música do passado aos novos meios de reprodução visando uma atualização da sua expressão tendo em vista o mundo moderno.

A simples recuperação do repertório e das partituras de notação ainda não totalmente racionalizadas serviram de inspiração e modelo para muitos compositores da Música Nova. Anton Webern desenvolveu seu doutorado com pesquisas sobre a música renascentista de onde tirou muito de sua técnica de contraponto, e por exemplo, Gyorgy Ligeti recorre a Ockeghen para compor suas texturas de polifonia saturada. Neste sentido é simbólico que muitas vezes o interesse dos pesquisadores de música antiga decaiam sobre os elementos mais modernos desta música. É a música antiga nova: Notações não mensuradas, fantasias, ricercares de forma fluída, polifonias cromáticas ou de densidade sublime, modalismos expandidos, o fascínio pela dissonância e 
informidade da música reservata, são elementos que ganham caráter de modernidade e verdade crítica perante a ideologia do século XIX dominante até hoje. O caminho da emancipação da dissonância que teve seu ápice na música nova do século XX recupera seu passado oculto. Assim, antes de decidir como interpretar a obra, reconhecer qual obra ainda tem valor para ser interpretada é uma das tarefas mais autênticas do interprete de música antiga. Como afirma Adorno em seu ensaio sobre Bach, trata-se de ver como:

“o passado se transforma em meio para enquadrar forçosamente o contemporâneo no futuro da própria evolução. (...) o passado longínquo transforma-se em portador da utopia do sujeito-objeto musical, o anacronismo transforma-se em mensageiro do futuro."

(ADORNO, 1998, p. 144)

Do primeiro modelo de recuperação, o da fidedignidade ao espirito da época, a música antiga tem sua verdade em diversos elementos, mas também pode decair em falsidades. A capacidade de reconstruir a maneira como o intérprete desempenhava a música ao espírito do passado - que por um lado marca de um certo humanismo de nossa época - restitui, assim como na música nova, o papel expressivo e criador do intérprete. Uma máquina jamais vai tocar uma peça de música non mesure. Haveria por outro lado que se reconhecer os limites de quão livre seria esta expressão, já que esta deve ser orientada por rígidas indicações em uma porção de tradados e métodos, sem falar no alto risco da interpretação arbitrária. A própria recuperação dos instrumentos de época, que novamente em paralelo com a música nova apresentam um novo mundo de timbres e texturas, pode decair num fetichismo do instrumento, assim como a música nova se vê encantada com os novos sons na música eletrônica. Como afirma Harnoncourt:

\footnotetext{
"a autenticidade sonora pode constituir, para muitas obras, uma ajuda fundamental, mas em outros casos, justamente por causa de seu caráter espetacular, pode cair num absurdo fetichismo do som" (HARNONCOURT, 1998, p. 89).
}

Neste mesmo sentido a música antiga ao restaurar a função do intérprete no centro da recriação da obra corre o mesmo risco da música nova e da cultura pop de recair no fetichismo da personalidade interpretativa. Isso para não falarmos na interpretação que visa literalmente reconstituir os costumes e modos de vida do passado, 
o que sempre parece decair no kitsh mais falso, em geral, embebido de superstição religiosa. Mas mesmo diante de tais riscos, a busca por uma interpretação que não decaia nos arroubos e exageros da expressão romântica já se apresenta como forte crítica com alto teor de verdade em uma sociedade dominada pelo pathos expressivo da genialidade exacerbada do romantismo.

Foi esta tradição romântica que tratou por inaugurar o movimento de música antiga, mas sempre adaptando a música do passado ao novos meios, sem preocupações histórico estilísticas. Trata-se da música antiga que é submetida a adaptações, orquestrações, e interpretações mais livres, tendo em vista diretamente as condições do presente. Neste lado o perigo é muito maior, bastando lembrar as recriações monstruosas que a tradição romântica deixou como legado, quando almejava divulgar peças de música antiga para teatros de milhares de pessoas, o que só ressalta a verdade da música de câmara com instrumentos antigos. No entanto, como vimos, ao se adaptar a música antiga para novas orquestrações como faz Webern com o Ricercare de Bach, ou então, como faz Schoenberg com A fuga em mi bemol maior também de Bach, é possível reconhecer que estas adaptações fazem surgir um elemento contrapontístico muitas vezes oculto numa interpretação feita, por exemplo, por um consorte de violas. A adaptação que visa esclarecer o processo composicional da obra e fazer vir à tona um elemento verdadeiro pode ser incongruente com a história, mas não incongruente com a história que passa diante de nossos olhos. A música antiga deve buscar sempre ser música nova.

Para concluir lembramos aqui de Glenn Gould. Talvez Gould seja uma espécie de modelo, pois era capaz de interpretar a música mais nova e ao mesmo tempo ter uma paixão por compositores da antiguidade, sempre trazendo a tona aspectos tão historicamente orientados como muitas vezes ultrapassando-os e deformando-os. Nas palavras de Harnoncourt: "é preferível uma execução inteiramente errônea, do ponto de vista histórico, porém viva musicalmente.” (HARNONCOURT, 1998, p. 19) A preocupação de Gould assim parecia ser muito mais a de uma expressão verdadeira que fizesse jus a seu tempo, do que uma verdade que faça jus ao tempo passado simplesmente. Gould foi também neste sentido alguém que sentiu na pele e refletiu os problemas do fetichismo do intérprete, os problemas da reprodutibilidade técnica e o isolamento da música verdadeira do público. Seu abandono dos palcos e a gravação de milhares de programas de rádio a isto vem dar testemunho. Para nós, resta ouvir os 
murmúrios em suas gravações que nos lembram que há um ser humano por traz daquela música.

Vivemos num mundo sem história cujo futuro nunca nos pareceu tão incerto e tão dominado pela expectativa da catástrofe, dominado pela máquina capitalista que apartou a vida da novidade, a mergulhou no tédio e na diversão vulgar em torno da reprodução do mundo do mercado. É por isso e contra isso que é central para a reflexão e prática musical atualmente a seguinte questão: como interpretar o passado a luz do nosso tempo?

Excurso II - A fantasia formal de Ligeti. A partir de problemas apresentados tanto pelas obras quanto pelas reflexões estético-musicológicas de Ligeti, trata-se neste excurso de aprofundar algumas articulações entre os conceitos da estética musical de Adorno.

Adorno, em diversos momentos de sua reflexão estética, sempre apontou como as mais relevantes e verdadeiras obras de arte o são devido a sua capacidade de - no interior de seus processos constitutivos, expressão e construção - tematizar, desenvolver e resolver problemas históricos da linguagem a que se referem. Numa analogia, seria como se arte cortasse e recosturasse o tecido histórico que ela herda e que a constitui, vestindo adequadamente o corpo que se lhe apresenta no presente.

Antes de reconhecermos na obra de Ligeti tal conteúdo de verdade, sempre saltava a nossa escuta a capacidade do compositor apresentar com clareza a construção estrutural e formal de suas composições, aliado a uma forte expressividade inovadora e questionadora. Destes primeiros contatos que já nos despertavam questionamentos e desafios auditivos, ao aprofundarmos os estudos das obras de Ligeti fomos nos dando conta de que tal sensação estética se concretizava objetivamente no desenvolvimento de sua própria experiência composicional.

Para além do interesse específico de suas obras, também nos surpreendeu a grande capacidade de articulação teórica do compositor contida em seus ensaios sobre a 
música. Dali notamos sua forte relação com a estética de Adorno, relação esta que tornou-se um dos pontos centrais de nossa pesquisa de mestrado, mas que infelizmente só poderá ser aprofundada em projetos futuros. Nosso objetivo aqui se restringe a elaborar uma reflexão sobre a resposta ligetiana dos anos 60 aos problemas colocados pela produção musical da geração pós-45, respostas estas que de maneira reveladora se aproximam muito das concepções e intervenções estéticas de Adorno.

Mimese e racionalidade. Ao nos debruçarmos sobre a experiência composicional de Ligeti - flertando com toda a heterogeneidade que povoa suas obras, que vão desde o realismo soviético na Hungria até os mais formalistas cânons de seus estudos para piano - esta se nos apresenta como uma experiência idiossincrática, que no seu processo histórico inelutável de transformações durante toda uma vida, guarda uma marca fisionômica, como gestos e digitais que o compositor imprime sobre o material. Longe de desconsiderar a determinação social da situação a que uma experiência composicional está submetida, arriscamos dizer que a grande marca de Ligeti tenha sido a da solidão em busca da liberdade composicional. Afinal, Ligeti sempre foi aquele que rejeitava programas vanguardistas, e que suspeitava de compositores que passavam a vida toda compondo da mesma maneira.

De maneira esquemática, se atentarmos a totalidade da produção ligetiana é possível dividi-la em 3 momentos gerais: a primeira pode ser chamada de fase húngara que vai de 1938 até 1956; a segunda é chamada de fase textural, com obras marcadas pelo uso da polifonia saturada, escritas na sequência da vinda de Ligeti ao ocidente, quando teve contato com a produção mais avançada da Europa central; e por fim a terceira é chamada de fase híbrida, aquela marcada heterogeneidade de materiais e técnicas, que dura de meados dos anos 60 até a morte do compositor em 2006.

Neste texto nos focaremos na obra que marca a transição da fase húngara para a fase textural: Aparições para orquestra. Nesta obra é possível reconhecer uma problematização e resposta a uma série de questões que estavam presentes naquilo que podemos chamar de espírito da época materializado na força produtiva composicional.

Aparições foi composta entre 1957 e 1959. Num texto intitulado "Estados, Eventos e Transformações" Ligeti descreve um sonho que lhe serviu de inspiração para tal obra: 
“Certa vez na minha infância eu sonhei que não conseguia chegar até minha pequena cama (a qual possuía barras, o que para mim significava certa segurança) pois o quarto todo estava tomado por um fino algodão, mas que era denso como uma teia altamente trançada, similar as secreções com que os bichos-da-seda preenchem seus casulos enquanto estão no estágio larval. Ao meu lado outras criaturas vivas e objetos estavam presos nesta imensa teia: mariposas e besouros de todos os tipos tentavam alcançar a oscilante chama de uma vela no canto do quarto; travesseiros enormes, sujos e úmidos, cuja estopa caia por furos na fronha, todos presos naquela teia. Qualquer movimento de um inseto imobilizado fazia com que a teia chacoalhasse e vibrasse de tal forma que os travesseiros balançavam para frente e para traz; isto por sua vez, fazia tudo tremer ainda mais. Muitas vezes os movimentos recíprocos tornavam-se tão violentos que a teia estourava em certos pontos e alguns insetos eram inesperadamente liberados, apenas para se enroscarem na sequência com um zumbido chocante na oscilante teia. Estes periódicos e súbitos eventos gradualmente alteravam a estrutura interna da teia, a qual se tornava ainda mais trançada. Em certos lugares nós impenetráveis se formavam; em outros, cavernas abriam-se e se podia ver por ali fios da teia original flutuando levemente. Estas transformações eram irreversíveis; nenhum estado anterior poderia recorrer. Havia algo de inexpressivamente triste neste processo: a irreversibilidade do passado e o desespero frente ao fluir inelutável do tempo. A memória deste sonho teve uma influência definitiva na música que eu escrevi no fim do anos 50.” (LIGETI, 1993, p. 165-171)

Ligeti de imediato faz uma série de ressalvas: não se trata de um programa musical, tudo se abstrai frente aos procedimentos técnicos e novas ideias surgem quando se passa a lidar com a pureza dos processos formais composicionais. A relação entre mimese expressiva do pesadelo e a racionalidade dos procedimentos que a constituem nos surge como atestação de um elemento central da estética de Adorno para quem: "A arte é a dialética entre o principio racional que confere forma e o princípio mimético. Para se apoderar deste se tem ajuda dos meios técnicos, dos procedimentos racionais com os quais entram em conflito.” Assim se há algo que resta desta mimese é um sentimento abstrato de terror e medo que se materializa na expectativa frente ao desenvolvimento temporal e formal da obra. Vejamos como isso se dá, nos focando principalmente no seu primeiro movimento.

O primeiro movimento de Aparições é constituído basicamente por dois tipos de material: um primeiro tipo são texturas mais ou menos estáticas conforme a organização 
intervalar ou timbrística, normalmente feitas por aglomerados indistintos de alturas cromáticas ou muito próximas uma das outras, que se constituem como blocos sonoros no tempo, chamados por Ligeti de estados. Ex: logo no início temos um intervalo de segunda menor harmônico nos baixos. Um segundo tipo de material que constitui a obra são eventos, sons e ruídos, ataques e fragmentos motívicos, que como os insetos surgem no interior da teia elaborada pelo $1^{\circ}$ tipo de material.

Ligeti organiza as durações de maneira serializada fazendo proporção entre as intensidades dos eventos e a força que estes transformam a textura ao fundo. A resultante espaço temporal da forma é um longo caminhar pelo campo de tessitura do grave ao agudo marcado por, oscilações, rupturas e rasgos.

“Como o grau de alteração dos estados é aproximadamente proporcional à força de ataque dos eventos, a impressão criada é de uma relação causal entre os eventos e a alteração dos estados. Esta relação causal é com certeza apenas aparente: ela é uma elemento da mera imaginação sintático-musical.”(LIGETI, 1993. P. 171.)

$\mathrm{Na}$ dimensão musicológica a obra responde a uma série de paradoxos de seu tempo, por sua vez materializados nas obras dos epígonos das vanguardas pós-45, principalmente diante das experiências do serialismo integral e da musica aleatória. Tais paradoxos e críticas Ligeti desenvolve principalmente nos textos: "Evolução da forma musical" e "Forma musical hoje", sendo este último marcado como vimos pela presença na mesma mesa de Adorno e Dahlhaus.

A centralidade da crítica de Ligeti diz respeito ao diagnóstico da espacialização estática da forma musical: fruto como vimos principalmente do abandono de esquemas formais preestabelecidos; da negação, tabula rasa da tradição, de qualquer sintaxe; unido à desfuncionalização dos materiais utilizados na música nova. A desfuncionalização dos materiais fez com que a forma possa se organizar independentemente de características naturais e históricas do som, partindo apenas de estruturas seriais matematizadas e escolhas arbitrárias, ou na abstenção de uma escolha formal específica como no caso do aleatório. O fato é que sem função geral, ao ser disposto na forma geral, o material musical passa a ser altamente intercambiável. Tal permeabilidade gera uma fraqueza na capacidade de clarificação do caráter vetorial da forma na produção pós-45. Tal fraqueza diagnosticada por Ligeti, gera uma cisão do 
processo composicional com a auditibilidade e uma indiferença com relação à resultante sonora, fruto da indiscriminação e equivalência dos intervalos.

A metáfora de Ligeti é a de uma foto de um móbile de Calder, com suas partes intercambiáveis de forma e direção indefinidas que são fixadas no resultado final da construção da obra. Diante de tal diagnóstico, nos impressionava ver como a obra de Ligeti incorpora tais problemas ao trazê-los para dentro da forma musical, os reformulando, problematizando e apresentado soluções.

Com auxilio de ideias técnicas aprendidas no estúdio de Colônia, como a variação de registros de frequência, Ligeti faz uso do plano de tessitura para dar desenho formal a sua obra. Incorporando aquilo que poderíamos chamar de estaticidade aparente dos clusters, Ligeti tematiza a própria estaticidade criticada. Em suas obras, buscando essa tematização da problemática, Ligeti é capaz de dialeticamente recuperar pela estaticidade a direcionalidade temporal. Tematizando a indiferenciabilidade das alturas do serialismo e da música aleatória Ligeti constrói complexos sonoros cuja individualidade dos sons já realmente não importa, mas sim o resultado aparente e de expectativa com a relação ao decorrer da peça. Conciliando e colocando em questão diversos avanços técnicos com a sua fantasia formal Ligeti é capaz de recuperar motivos construtivos da tradição, enfrentando a tabula rasa, com referências à melodia de timbres de Schoenberg, o preludio textural de Wagner no Anel ou as texturas moventes e estáticas do quattrocento, principalmente de Ockeghen.

É de enorme interesse estético, que mesmo conjugando a tradição e os mais sofisticados avanços técnicos da ciência musical, Ligeti ainda preserve algo da inspiração mimético expressiva de seu pesadelo, mostrando que a imaginação não deve ser abandonada no processo composicional. Seu sonho se apresenta na obra apenas de maneira abstrata, mas ousamos dizer que algo da mimese deste sonho resta na forma como expressão obscura do afeto de terror do pesadelo. Este impulso para a expressão do horror, do bizarro, do desespero, do noturno, é latente na escuta da obra, e marca de grande parte da composição moderna que traduz a memória dos sujeitos que viram diante de si os horrores da guerra e da miséria.

Se ainda nos dermos liberdade metafórica à comparação sociológica, como não lembrar da tensão estática da política na época e a expectativas de eventos cada vez mais intensos e catastróficos? Basta ter em mente o plano político da época que via a todo momento ameaçado pelo terror do grande evento, a bomba nuclear; assim como as notas, abstraídas de toda singularidade, os indivíduos, como os judeus e ciganos nos 
campos de concentração, se viam transformados em estatísticas, manipulados na história; e que dizer da dualidade estática que se via o futuro humano entre dois projetos tecno-belicistas do capitalismo ocidental e da fracassada experiência do comunismo soviético?

Mas voltemos ao imediato que interessava tanto às composições de Ligeti quanto às reflexões teórico poéticas de Adorno. Tratava-se de recuperar no processo de escuta e composição musical a capacidade de se construir a forma de maneira clara. Longe de apenas uma reconstrução da totalidade do processo, tratava-se de buscar a capacidade de apresentar seus contornos, para que a memória e a imaginação formasse e acompanhasse o processo de devir temporal: recuperar o sujeito no interior da obra e da escuta. Para tanto ambos, Adorno e Ligeti, visavam buscar na forma musical modelos ligados à ideia de organicidade, com a qual a forma se transforma e se metamorfoseia como em um ser vivo, por repetições e diferenças, ramificações e proliferações, mantendo unidade e coesão, enfim, apresentado a ideia da obra.

Por fim tanto Adorno como Ligeti exaltam a capacidade de tomar decisões quanto à disposição formal que para Ligeti deve se submeter ao interesse imaginativo do compositor e que para Adorno se materializa no senso formal. A liberdade do compositor aliada à consciência histórica deve se manifestar no compromisso com a arte e sua pretendida transformação da sensibilidade da humanidade. Ligeti e Adorno são modelos de pensamento que não se submete às reificações e ao conformismo mundano. Suas obras permanecerão vivas por muito tempo. 


\section{4 - Considerações finais}

Como considerações finais a este trabalho vale levantar criticamente nossas realizações, suas lacunas e trabalhos por fazer, quiçá em um projeto de doutorado. Pensamos que de forma aprofundada fomos capazes de apresentar a dinâmica geral do pensamento de Adorno no que diz respeito às categorias de técnica e expressão. A atualidade deste debate é latente. Por toda a parte é possível encontrar na situação da arte um vazio no que diz respeito à articulação entre linguagem e técnica, entre a dominação do som e a sua manifestação artística. $\mathrm{O}$ caráter de expressão, o reconhecimento do momento linguístico da arte parece ter ficado em segundo plano no âmbito dos debates estéticos. O objetivismo e o descompromisso marcado na arte como puro fazer parecem calar qualquer elemento crítico. As recentes tendências que buscam superar o próprio termo "música" em prol de arte sonora atestam este fato. A ausência e a crise dos critérios parece servir de justificação para um fazer indiferente ao papel da arte no interior da sociedade. É certo que seu isolamento numa esfera de especialistas, principalmente restrita ao meio universitário também contribui para esta situação esquizofrênica. Na tensão entre técnica e expressão buscamos apresentar a utopia adorniana que toda música contém. A música como cantar das musas contra o falso encantamento do mundo, o sonho de liberdade diante da inevitável dissolução que estamos submetidos pela ordem capitalista. 
Quanto à reconstrução histórica do debate na primeira metade do século elaboramos de maneira precisa os ataques vanguardistas à concepção tradicional de obra de tempo e de aparência. O maquinismo e tecnicismo do futurismo, ao lado do objetivismo de Stravinski nos parecem de extrema relevância para a compreensão do estado atual da arte. Por outro lado o expressionismo, incompreendido até hoje pela sociedade, permanece vivo com sua subjetividade fraturada e sua esperança desesperada. Quanto à década de 50 e 60 conseguimos apontar o principal diagnóstico de Adorno, o envelhecimento da nova música e a espacialização das manifestações musicais, mas certamente poderíamos nos debruçar mais e melhor sobre outros textos do filósofo e dos compositores da época em um trabalho que certamente ficou por concluir. A espacialização do tempo da pesquisa em ciências humanas a isso vem dar seu testemunho. O tempo cronométrico da pesquisa desconsidera a liberdade no trabalho do conceito e eventuais acontecimentos na vida do pesquisador.

Por fim nos dois excursos que concluem este trabalho apresentamos nosso interesse direto na prática musical, seja no campo da interpretação seja no plano da composição. O trabalho filosófico em nossa experiência acadêmica e artística opera, de certa forma, o mesmo papel que em Adorno. Buscamos encontrar no interior da reflexão abstrata da filosofia, e especificamente da estética, questões que tocam diretamente o plano de nosso próprio engajamento na práxis musical. Certo de que a formação de um artista envolve um conhecimento crítico de sua situação, pensamos que estamos perto de concluir um importante passo na formação de um espirito crítico engajado e consciente da situação atual das artes, condição fundamental para uma expressão artística verdadeira e consciente. Nosso esforço sempre foi neste sentido e continuará daqui em diante. A enorme habilidade de Adorno em circular em meios tão distintos como a filosofia e práxis artística seguirá sendo nossa inspiração e modelo, sem a isso se apegar de maneira a-critica e reificada. Aprendemos com Adorno que a auto-crítica é o momento fundamental da elaboração das verdades e que para criar uma obra de arte verdadeira é preciso antes reconhecer seu fracasso e sua utopia no interior da situação a que estamos inseridos: essa é a fantasia que gostaríamos de dar forma tanto na prosa quanto na própria prática musical. 


\section{6 - Bibliografia}

1. ADORNO, T.W., Alban Berg- Lê maître de la transiton infime, ed.

Gallimard, Paris, 1989.

2. ADORNO, T.W., Beethoven: The Philosophy of Music. Stanford University Press, EUA, 1998

3. ADORNO, T.W \& BERG, A. Correspondence 1925-1935, trad. Wieland Hoban. Ed. Polity, 2005.

4. ADORNO, T.W., Disonancias, trad. Vega, R. de la , Ed. Rialp S.A., Madrid, 1966..

5. ADORNO, T.W. Dialética do Esclarecimento. Rio de Janeiro: Jorge Zahar Editor, 1985

6. ADORNO, T. W. Dialética negativa. Trad. Marco Antonio Casanova. Rio de Janeiro: Jorge Zahar Ed., 2009

7. ADORNO, T.W., Essays on Music, ed. University of California, Berkley, Los Angeles, London, 2002 
8. ADORNO, T.W., Fetichismo da Música e Regressão da Audição. in Os Pensadores, Ed. Nova Cultural, 1998, São Paulo.

9. ADORNO, T.W., Filosofia da Nova Música. trad. França, M. , Ed.

Perspectiva, 2002.

10. ADORNO, T.W., Introducion a la Sociologie de la Musique. trad. Barras,

$$
\begin{aligned}
& \text { V. e Russi, C., ed. ContreChamps, } \\
& \text { França,1994. }
\end{aligned}
$$

11. ADORNO, T.W., Mahler,- Uma Fisiognómica Musical. trad. Pascual,A.

S. ed. Península, Barcelona, 1987.

12. ADORNO, T.W, Palavras e Sinais: modelos críticos 2. Trad. de Maria

Helena Ruschel. Petrópolis: VOZES. 1995

13. ADORNO, T.W., Prismas, crítica cultural e sociedade. , Ed. Ática, 1998

14. ADORNO, T.W., Quasi una Fantasia. Trad. Livingstone, R., ed. Verso, London 1998.

15. ADORNO, T. W., Teoria Estética. Edições 70, Lisboa, Portugual.1970.

16. ADORNO, T.W., Théorie Esthétique, Ed. Klincksieck, Paris,1974.

17. ADORNO, T.W., Obra completa, vol. Escritos Musicales (13,14,16, 17,18,19). Ed. Akal ,Madird, Espanha.2008

18. AgOstinHO, S. Confissões. 3a. ed. Trad. de J. Oliveira Santos, S.J. e A. Ambrósio de Pina, S.J. São Paulo: Abril Cultural, 1984

19. AlMEIDA, J. de, Crítica Dialética em Theodor Adorno. Atelie Editorial, Cotia, São Paulo, 2007.

20. BAGGIO, I. O dodecafonismo Tardio de Adorno. Ed. Unesp. 2011. 
21. BATTEUX, C. As belas-artes reduzidas a um mesmo princípio. Trad. Natalia Maruyama. Humanitas \& Imprensa oficical, 2009.

22. BENJAMIN, W. A obra de arte na época de sua reprodutibilidade técnica. São Paulo, Ed. Abril, 1980.

23. BENJAMIN, W. Origem do drama trágico alemão. Ed. Autêntica, Belo Horizonte, 2011.

24. BEnJAmIn, W. Obras escolhidas. Magia e Técnica, Arte e Politica. Ed. Brasiliense. 2012.

25. BOISSIÈRE, A., Adorno, la vérite de la musique moderne. Presses Universitaires Du Septentrion.

26. BOUlEZ, P., A Música Hoje. Ed. Perspectiva 1, 2, São Paulo, 1992

27. BOULEZ. P. Apontamentos de Aprendiz, Ed. Perspectiva, São Paulo, 1995.

28. BÜRGER, P., Teoria da Vanguarda, Trad. Antunes, P.F., Ed. Cosacnaify, 2008.

29. CAGE, J., De segunda a um ano. Trad. Duprat, R., Ed. Hucitec, São Paulo, 1985.

30. CAGE, J. Silence: Lectures and Writings, Wesleyan University Press, 1961.

31. DAHLHAUS, C., The Idea of Absolute Music. Chicago Press, EUA, 1991.

32. DAHLHAUS, C., Estética Musical, Edições 70, 1993.

33. DAHLHAUS, C. Schoenberg and the new music. Trad. Derrick Puffet . Cambridge University Press, 1989.

34. DELIÈGE, Célestin. Cinquante Ans de Modernité Musicale: de Darmstadt à L'IRCAM. ed. Mardaga. Bélgica, 2003

35. DUARTE, R., Expressão Estética: Conceito e Desdobramentos, in Mímesis e Expressão, Org. Duarte, R. e 
Figueiredo, V., ed. UFMG, Belo

Horizonte, 2003

36. EIMERT, H., The Composer's Freedom of choice. em die Reihe, Musical

Craftsmanship, Theodore Presser C.,1959.

37. FUBINI, E., La estética musical desde la Antiguidad hasta el siglo XX,

Alianza Editorial, Madrid, 2010.

38. FUBINI, E. , Música y Lenguaje en la estética contemporánea, trad.

ARANDA, C.G.P., Alianza Editorial,

Madrid, 1994.

GOETHE, J. W., A metamorfose das plantas. Trad. Molder, M.F.. Imprensa Nacional.

39. GROUT \& PALISCA, História da música ocidental, ed. Gradiva.2011.

40. HANSLICK, E. Do Belo Musical, Ed. Unicamp. 1989

41. HARNONCOURT, N. O discurso dos sons: caminhos para uma nova compreensão musical. Rio de Janeiro. Jorge Zahar, 1998.

42. LIGETI, G. Neuf Essais sur la musique. trad. Fourcassié, C., Editions Contrechamps, Genéve,2001.

43. LIGETI, G. States, Events, Transformations, Perspectives of New Music, Vol. 31, n.1, 1993.

44. LUKÁCS, G., A Teoria do Romance. trad. Macedo, J. M. M., Ed. 34, São Paulo,2003.

45. MAHLER, G, Gustav Mahler's Letters 1879-1911, Berlim, 1924. 
46. MENEZES, F., Apoteose de Schoenberg, ed. Edusp,1985.

47. MONJEAU, F., La invención musical, Ed. Espacios Del saber, Argentina, 2004.

48. PADDISON, M., Adorno's Aesthetics of Music, Cambrigde Press, 1997.

49. POUSSEUR, H., Apoteose de Rameau, Ed. Unesp, São Paulo, 2008

50. RAMEAU, J. P.,Treatise on Harmony, Courier Dover Publications, 1971

51. SADIE, S. Dicionário Groove de Música, Zahar, 1994.

52. SAFATLE, V., Fetichismo e Mimesis na filosofia da Música adorniana, em Discurso n.37, Ed. Alameda, São Paulo, 2007.

53. SAFATLE, V., O novo Tonalismo e o esgotamento da forma crítica como valor estético, in Ensaios sobre Música e Filosofia, org. Duarte, R. e Safatle, V., ed. Humanitas, 2007.

54. SCHOENBERG, A., Modelos Para Estudantes em Composição, Ricordi, 1943

55. SCHOENBERG, A., Style and Idea. California Press,1984.

56. SCHOPENHAUER, A. O mundo como Vontade e representação, Trad. Jair. Barboza. São Paulo: Ed Unesp, 2005.

57. STOCKHAUSEN, K. ....How Time Passes....,, em die Reihe, Musical

Craftsmanship, Theodore Presser C.,1959.

58. WAGNER, R. Beethoven, Ed. Jorge Zahar, 2010.

59. WEBER, M. Fundamentos racionais e sociológicos da música. São Paulo: Edusp, 1995. 
